\title{
AVALIAÇÃO CLÍNICA E HISTOLÓGICA DOS EFEITOS DO LASER EM BAIXA INTENSIDADE (GaAIAs) NA CICATRIZAÇÃO DE GENGIVOPLASTIA EM HUMANOS
}

Carla Andreotti Damante

Dissertação apresentada à Faculdade de Odontologia de Bauru, da Universidade de São Paulo, como parte dos requisitos para obtenção do título de Mestre em Odontologia na área de Periodontia 


\section{AVALIAÇÃO CLÍNICA E HISTOLÓGICA DOS EFEITOS DO LASER EM BAIXA INTENSIDADE (GaAIAs) NA CICATRIZAÇÃO DE GENGIVOPLASTIA EM HUMANOS}

Carla Andreotti Damante

Dissertação apresentada à Faculdade de Odontologia de Bauru, da Universidade de São Paulo, como parte dos requisitos para obtenção do título de Mestre em Odontologia na área de Periodontia

Orientador: Prof. Dr. Sebastião Luiz Aguiar Greghi 


\section{DI8a Damante, Carla Andreotti}

Avaliação clínica e histológica dos cfcitos do laser em

baixa intensidade (GaAlAs) na cicatrização após

gengivoplastia em humanos/Carla Andreotti Damante. - Bauru, 2003.

92 p.; $30 \mathrm{~cm}$

Tese (mestrado) - Faculdade de Odontologia de Bauru - USP

Orientador: Prof. Dr. Scbastião Luiz Aguiar Greghi

Autorizo, exclusivamente para fins acadêmicos e cientificos a reprodução total ou parcial desta tese, por processos fotocopiadores e/ou meios eletrônicos.

Assinatura do autor:

Data: $20 / 04 / 03$

Número do protocolo do comitê de ética da FOB-USP: não existe Aprovado $\mathrm{cm} 30 / 11 / 2000$. 


\section{Carla Andreotti Damante}

19 de junho de 1979

$1996-1999$

$2001-2003$

Associações
Nascimento

Bauru - SP

Curso de Odontologia na

Faculdade de Odontologia

de Bauru - USP

Curso de pós-graduação

em Periodontia, nível de

mestrado,

na Faculdade de

Odontologia de Bauru -

USP

APCD - Associação

Paulista de Cirurgiões

Dentistas

$\mathrm{SBPqO}$ - Sociedade

Brasileira de Pesquisa

Odontológica

IADR - International

Association for Dental

Research 


\section{DEDICATÓRIA}

Dedico este trabalho:

Aos meus pais e a minha avó que sempre lutaram e ainda lutam para que eu siga os caminhos certos e seja uma pessoa cada vez melhor.

A minha irmã, amiga e companheira de todas as horas.

Ao Gustavo, que acrescentou muito carinho e amor à minha vida e fez com que os momentos de tempestade durassem pouco e os de alegria perdurassem por muito tempo.

Aos meus grandes amigos Alessandra, Alessandro, Flávia, Heitor, Jefferson e Nicole, que dividiram comigo horas boas e ruins e com quem eu pude e posso contar a qualquer momento. Sou uma pessoa mais feliz por ter amigos como vocês. 
“Antes do compromisso há hesitação, oportunidade de recuar. Em todo ato de iniciativa (e de criação) há uma verdade elementar, cujo desconhecimento destrói muitas idéias e planos esplêndidos. No momento em que nos comprometemos de fato, a providência também age. Ocorre toda espécie de coisas para nos ajudar, coisas que de outro modo nunca ocorreram. Toda cadeia de eventos emana da decisão, fazendo vir em nosso favor todo tipo de encontros, incidentes e de apoio material, imprevistos com que não se poderia sonhar, que surgiriam em seu caminho. Por isso, começas tudo o que possas fazer ou que sonhas poder fazer. A ousadia traz em si o gênio, o poder e a magia!”

GOETHE 


\section{AGRADECIMENTOS}

Aos pacientes que participaram deste estudo, pela colaboração e por deixaram um pouco de si na minha memória e no meu aprendizado pessoal.

Ao Prof. Dr. Sebastião Luiz Aguiar Greghi, pela orientação deste trabalho e de muitos outros, pela amizade e pela oportunidade de pesquisar numa área que sempre me agradou.

Ao Prof. Dr. Rumio Taga, pela orientação da parte histológica deste trabalho, e que me fez conhecer um novo mundo de pesquisa e saber através das lentes do microscópio.

Ao Prof. Dr. Euloir Passanezi, por ter ensinado Periodontia na teoria e na prática de forma marcante e por todas as sugestões dadas para o desenvolvimento desta tese.

Ao Prof. Dr. Deoclécio Nahás (in memorian), pela experiência transmitida durante minha graduação e permanência no Departamento de Periodontia.

À Prof ${ }^{a}$ Dr $^{\text {a }}$ Marilia Afonso Rabelo Buzalaf, a quem devo toda a minha formação como pesquisadora e pela orientação de muitos trabalhos.

Ao Prof. Dr. José Roberto Pereira Lauris, pela realização da análise estatística desta tese.

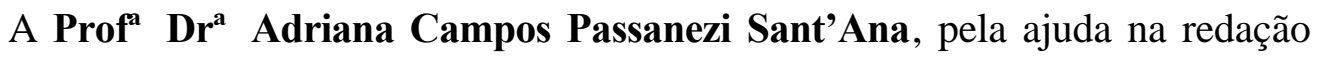
do resumo e abstract deste trabalho.

Aos colegas de mestrado Caio, Dioracy, Eric, Márcio, Mariana, Marinelle, Milena, Stéfano, pela ajuda, pela amizade, pela troca de conhecimentos, pela convivência agradável durante todo esse tempo. Este trabalho tem um pouquinho de 
cada um de vocês.

A Ivânia, cuja ajuda foi indispensável para a realização de todas as etapas deste trabalho, além da amizade e da presença em todos os momentos.

A Edilaine, Marcos, Neusa e Débora que tornaram agradáveis as horas de convivência na Periodontia. Com certeza aprendi muito com cada um de vocês.

A Daniele e Tânia, pela ajuda que foi fundamental para realização da fase histológica desta tese. A companhia de vocês tornou mais divertidos os períodos intermináveis da análise morfométrica no laboratório de Histologia.

Aos estagiários Aline, Juliana, Celene, Rodrigo, Patrícia, Danilo, César pelo auxílio na fase cirúrgica deste trabalho e pela troca de aprendizado que tivemos nesses dois anos.

Ao Heitor, que me ajudou a lidar com os pacientes mais "rebeldes" e me ensinou que algumas técnicas de Odontopediatria servem até para os mais adultos.

Aos colegas do doutrorado, Damé e Daniel Resende, pela participação na análise clínica deste trabalho.

A Eloisa Maria Pagani Pereira, pela correção da ortografia e gramática desta tese.

Ao Prof. Dr. Carlos de Paula Eduardo, pela oportunidade de participar do curso Utilização Clínica do Laser no LELO- Laboratório Experimental de Laser em Odontologia da FOUSP.

À Faculdade de Odontologia de Bauru, que me formou uma profissional capacitada na prática, na teoria e na pesquisa, durante a graduação e pós-graduação, com os melhores professores, funcionários e equipamentos. 


\section{SUMÁRIO}

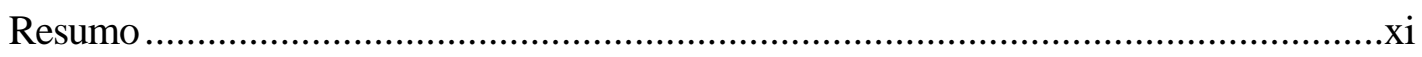

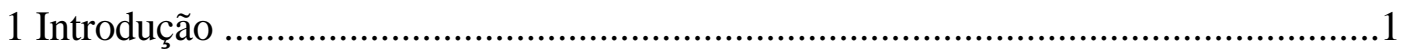

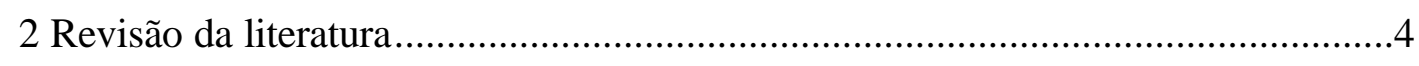

2.1 Cicatrização após gengivectomia/gengivoplastia ..................................4

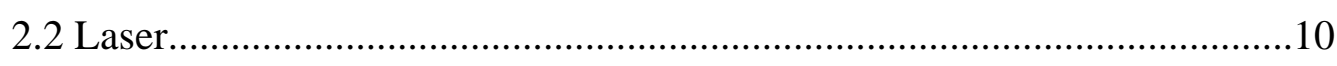

2.2.1 Biofísica do laser...............................................................10

2.2.2 Lasers em baixa intensidade ...................................................14

2.2.3 Laser em baixa intensidade na cicatrização de feridas ..................19

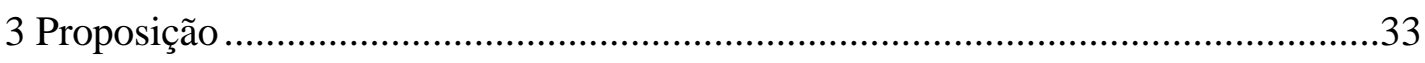

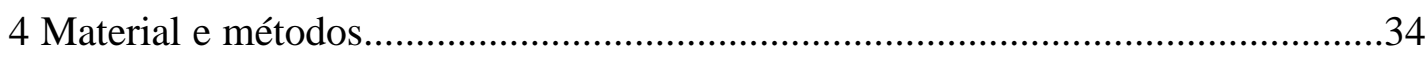

4.1 Seleção dos pacientes........................................................................ 34

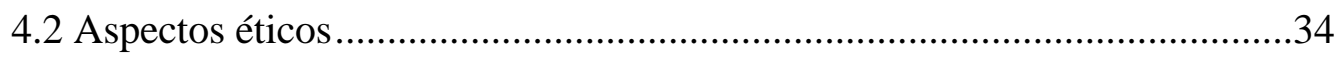

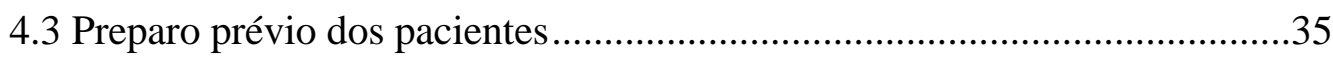

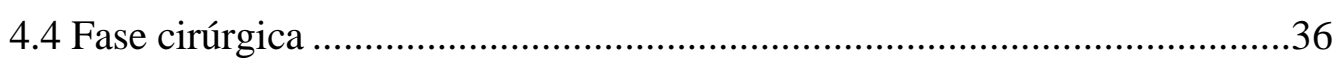

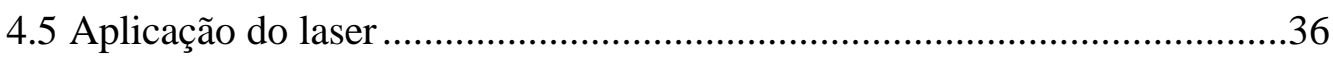

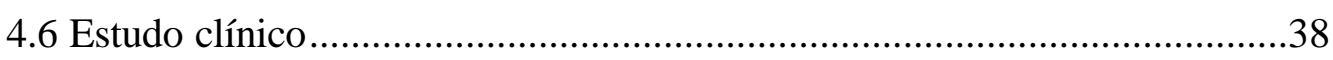

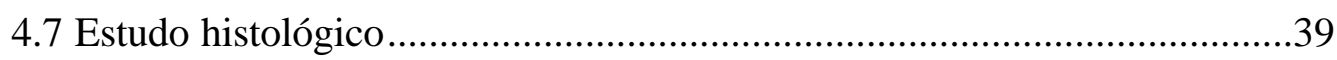

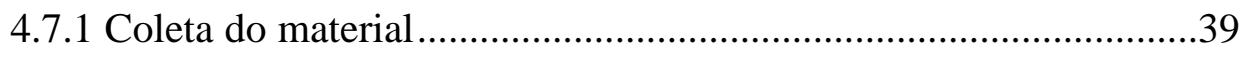

4.7.2 Processamento histológico .......................................................40

4.7.3 Análise estereológica ...........................................................41

4.7.3.1 Casualização dos campos histológicos .............................42

4.7.3.2 Análise do tecido epitelial nas diferentes

fases de maturação .........................................................42 
4.8 Análise estatística dos dados clínicos e histológicos .................................46

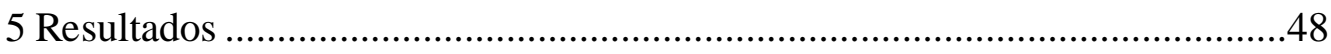

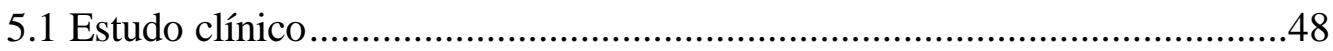

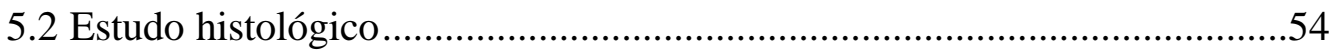

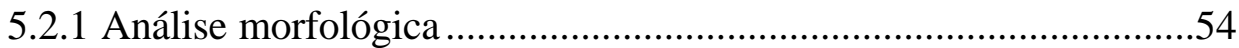

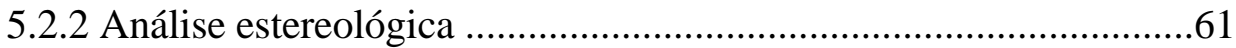

6 Discussão

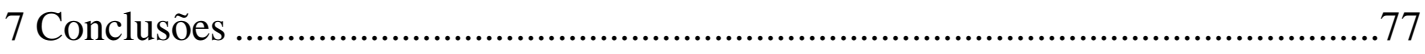

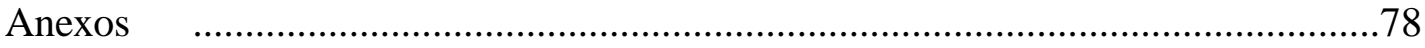

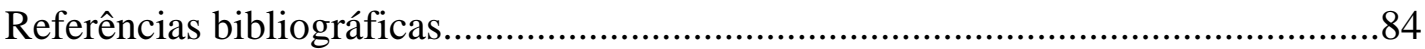

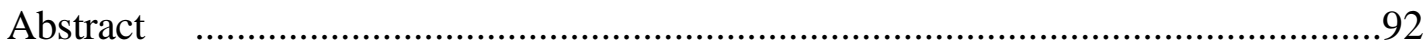




\section{LISTA DE ABREVIATURAS E SÍMBOLOS}

$\mu \mathrm{m}$ - micrometros

$\mu \mathrm{m}^{3}$ - micrometros cúbicos

${ }^{\circ} \mathrm{C}$ - graus celsius

CFO - conselho federal de odontologia

$\mathrm{CO}_{2}$ - dióxido de carbono

GaAs -arseneto de gálio

GaAlAs - arseneto de gálio e alumínio

Gy - gray

H.E. - hematoxilina eosina

He-Ne - hélio-neônio

$\mathrm{Hz}-$ hertz

$\mathrm{J} / \mathrm{cm}^{2}$ - joules por centímetro quadrado

LILT - terapia com laser de baixa potência

$\mathrm{mJ} / \mathrm{cm}^{2}$ - milijoules por centímetro quadrado

$\mathrm{mW}$ - miliwatts

nm - nanômetros

UVB - ultravioleta beta

W - watts

$\mathrm{W} / \mathrm{cm}^{2}$ - watts por centímetro quadrado 


\section{RESUMO}

A terapia com laser em baixa intensidade visa, principalmente, supressão da dor e aceleração da cicatrização de feridas. Este estudo teve por objetivo, avaliar clinica e histologicamente os efeitos do laser de arseneto de gálio e alumínio (GaAlAs) - 670nm na aceleração da cicatrização de gengivoplastias em 13 pacientes. Após a cirurgia, o lado direito (teste) recebeu aplicação do laser com dose de $4 \mathrm{~J} / \mathrm{cm}^{2}$, a cada 48 h, durante 1 semana, totalizando 4 sessões. O lado esquerdo (controle) não foi irradiado. Cinco examinadores avaliaram, comparativamente, o aspecto clínico da cicatrização através de fotografias dos períodos pós-cirúrgicos de 7, 14, 21,30 e 60 dias. Nos períodos de 7 a 21 dias, houve preferência ora por um, ora por outro lado como o mais bem cicatrizado e nos períodos subseqüentes, ambos foram considerados iguais. Para a avaliação histológica, foram realizadas biópsias incisionais, próximas da papila mesial dos caninos, em ambos os lados, nos períodos pós-operatórios de 7,14, 21 e 60 dias. A análise morfométrica da maturação epitelial e conjuntiva mostrou que a cicatrização ocorreu dentro de parâmetros normais em ambos os lados. Para a análise estatística dos dados clínicos foram utilizados os testes dos sinais e Kappa. Houve baixa concordância entre examinadores com valores médios de Kappa entre 0,17 e 0,36. Para os dados morfométricos aplicou-se o "teste t" pareado, com nível de significância de 5\%. ( $\mathrm{P}<0,05)$. Os resultados não

mostraram diferenças estatisticamente significantes entre os grupos, levando à conclusão que, do ponto de vista clínico e histológico, o laser não influenciou a cicatrização da mucosa bucal. 
1 INTRODUÇÃO 


\section{INTRODUÇÃO}

A luz tem sido utilizada como agente terapêutico por séculos. Na Grécia antiga, o sol era empregado na helioterapia, ou seja, exposição do corpo à luz solar para restauração da saúde. Na Idade Média o sol era utilizado para combate da praga. Muitos séculos depois, a luz ainda é utilizada para tratamento de psoríase, hiperbilirrubinemia e outras doenças ${ }^{5}$. Partindo do princípio de que a luz pode curar doenças, o laser, que é um tipo de luz, foi introduzido nas ciências da saúde.

A palavra LASER é um acrônimo de Light Amplification by Stimulated Emission of Radiation, a qual pode ser traduzida por amplificação da luz por emissão estimulada de radiação. A partir da teoria de emissão estimulada de radiação, descrita por EINSTEN e publicada em 1917, SCHAWLOW E TOWNES, em 1958, desenvolveram o MASER ${ }^{34,65}$. (Amplificação de microondas por emissão estimulada de radiação). De acordo com GOLDMAN ${ }^{16}$, os princípios do maser, que posteriormente dariam origem ao laser, foram primeiramente descritos por aqueles autores, mas o prêmio Nobel pela descoberta do laser foi dado a TOWNES, BASOV e PROKHOROV em $1964^{34}$.

O primeiro laser, construído por MAINMAN em 1960, foi o de Rubi ${ }^{5}$. Na área da Odontologia os trabalhos iniciaram-se em 1963 e eram centralizados nos efeitos térmicos do laser nos tecidos duros do dente ${ }^{5}$. O primeiro relato do uso do laser de rubi em um dente vitalizado foi em 1965 por GOLDMAN ${ }^{5,34}$. A utilização do laser nas áreas biomédicas surgiu como consequiência natural de suas propriedades e se iniciou com o aproveitamento de seus efeitos térmicos. Os lasers de alta potência são capazes de vaporizar e coagular tecidos biológicos, oferecendo um campo cirúrgico sem sangramento e com certo grau de esterilização ${ }^{40}$. 
Outro campo de estudo nas áreas biomédicas é o da aplicação dos lasers de baixa intensidade. O princípio básico da terapia laser é que a irradiação com comprimentos de onda específicos tem a capacidade de alterar o comportamento celular na ausência de aquecimento. O laser estimula processos biológicos e, por isso, esse fenômeno foi inicialmente chamado de bioestimulação ${ }^{5}$. A bioestimulação é um termo genérico para qualquer estímulo, agente ou ação que produzam resposta fisiológica com aumento da atividade funcional ${ }^{40}$. Como foi comprovado que doses altas de laser podem inibir atividades celulares ${ }^{23}$, este termo - bioestimulação - não tem sido utilizado ${ }^{5}$. Hoje, o tratamento com laser em baixa intensidade é nomeado por uma gama variada de palavras como terapia laser, terapia com laser em baixa intensidade (LILT - low intensity laser therapy), laser em baixa intensidade, lasers “frios”, nomes que fazem menção às suas propriedades fotoquímicas ${ }^{5}$. A terapia com laser em baixa intensidade geralmente envolve a aplicação de 1 a $4 \mathrm{~J} / \mathrm{cm}^{2}$, nos locais de tratamento, com lasers que possuem potências de $10 \mathrm{~mW}$ a $90 \mathrm{~mW}{ }^{5}$. Entre os principais efeitos dessa terapia estão a supressão da dor e aceleração da cicatrização $^{40}$.

Um dos pioneiros na pesquisa com laser em baixa intensidade foi Endre Mester em Budapeste, Hungria, que publicou o primeiro trabalho em 1967, mostrando seus efeitos em pele de ratos $^{40}$.

A medicina do laser está tendo um rápido desenvolvimento e os efeitos da LILT têm sido publicados regularmente, principalmente na Europa oriental e Japão. Na Europa ocidental e América do Norte, essa terapia ainda tem sido vista com ceticismo ${ }^{54}$. A aceitação nos Estados Unidos ainda é baixa e o uso desses lasers ainda não é aprovado pelo Food And Drug Administration para todos os tipos de 
tratamento.

Esse ceticismo pode ser decorrente da publicação de trabalhos controversos na literatura, mostrando tanto efeitos benéficos como nenhum efeito da terapia com laser em baixa intensidade. Existem muitos trabalhos não publicados na língua inglesa, o que dificulta sua circulação pelo mundo. É muito comum, também, que uma investigação falhe em demonstrar um efeito particular por causa da escolha de parâmetros incorretos ${ }^{53,54}$. Há vários tipos de laser com diferentes especificidades e, ainda, pode haver falhas na dosimetria, modo de aplicação e modelo animal utilizado para o estudo. Existem muitos relatos sem controle adequado e com análise subjetiva dos resultados.

O uso do laser para acelerar a cicatrização é bastante pesquisado, porém a maioria dos trabalhos é realizada em animais ou cultura de células $3,6,17,18,21$, 26,30,31,32,33,42,43,46,56,62,63. Muitos autores, após revisarem e literatura sobre esse assunto, concluem que há necessidade de protocolos padrão e mais estudos controlados em humanos antes que o uso clínico dos lasers seja difundido ${ }^{11,57}$

LOWE et al. ${ }^{31}$, em 1998, sugeriram que para estudar alterações nos níveis celulares, mais estudos histológicos deveriam ser feitos. A histologia de rotina deveria ser utilizada para determinar tipos celulares, proliferação celular e vascular, produção de colágeno e resposta inflamatória.

Devido a deficiências das pesquisas na literatura, observourse a necessidade do desenvolvimento de um estudo em humanos, acompanhado de análise histológica detalhada que poderá avaliar os efeitos do laser, em nível microscópico oferecendo resultados mais consistentes. 
2 REVISÃO DA LITERATURA 


\section{REVISÃO DA LITERATURA}

\subsection{Cicatrização após gengivectomia/gengivoplastia}

A técnica da gengivectomia é uma das mais antigas abordagens cirúrgicas para tratamento da doença periodontal. $\operatorname{ROBICSEK}^{41}$, em 1884, foi um dos pioneiros a descrever o procedimento da gengivectomia com uma incisão linear na mucosa ceratinizada. Em 1918, ZENTLER ${ }^{64}$ descreveu a técnica com uma incisão que seguia o contorno da margem gengival. Mas foi a técnica descrita por GOLDMAN ${ }^{15}$, em 1951, a mais aceita e utilizada até os dias atuais. No presente trabalho, será considerado gengivoplastia o procedimento da remoção de tecido gengival em áreas de contorno ósseo íntegro, enquanto que gengivectomia é a excisão do tecido gengival em áreas que tiveram perda óssea horizontal.

A partir da década de 30 e 40, pode-se observar, na literatura, vários artigos que mostravam a dinâmica da cicatrização gengival após cirurgias de gengivectomia.

ORBAN; $\mathrm{ARCHER}^{37}$,em 1945, realizaram um estudo clínico e histológico para avaliar a cicatrização após cirurgias de gengivectomia em humanos. Foram selecionados pacientes que necessitavam de tratamento na região anterior que permitia melhor acesso para a observação. Secções de gengiva foram colhidas das áreas de papila de pré-molar a pré-molar, respectivamente aos 2,4,6,8,10,12 e 14 dias de pós-operatório, em um mesmo paciente. A análise histológica mostrou a formação de coágulo e inflamação aguda do tecido conjuntivo a qual foi diminuindo à medida que a cicatrização progredia. Houve completo recobrimento da ferida pelo epitélio aos 14 dias de pós-operatório. 
Em 1955, WAERHAUG ${ }^{55}$ realizou um trabalho em cães para estudar, clínica e histologicamente, se havia influência da extensão da incisão da gengivectomia na cicatrização. Foram utilizados 22 dentes em 2 cães com gengiva saudável. A primeira incisão da gengivectomia era feita no nível mais apical da bolsa periodontal. Nas observações clínicas, a reepitelização estava quase completa aos 14 dias. Nas primeiras duas semanas, a profundidade de sondagem era zero ou próxima de zero. Após esse período, o sulco gengival se desenvolveu chegando a uma profundidade de 0,5mm. Os autores sugeriram que a incisão não deveria ser radical e sim a $1 \mathrm{~mm}$ do fundo da bolsa para não haver destruição das fibras da inserção conjuntiva. Também notaram que seria impossível manter uma profundidade de sondagem de nível zero, porque, naturalmente, o sulco gengival voltaria a se formar.

Outro estudo histológico da cicatrização, após gengivectomia em humanos, foi realizado por RAMFJORD; $\mathrm{COSTICH}^{38}$ em 1963. Os pesquisadores utilizaram 10 dentes de nove pacientes que necessitavam de prótese total imediata. As amostras foram obtidas em vários períodos de tempo entre 0 e 44 dias de pós operatório. $\mathrm{Na}$ maioria dos casos, a reepitelização estava completa dentro de 7 dias e, aos 12 dias, houve início da ceratinização. Aos 44 dias de pós-operatório, o sulco gengival era formado e o epitélio juncional estava $0,1 \mathrm{~mm}$ apical às marcas de curetas feitas no pré-operatório. Os autores relataram que a formação do novo sulco gengival se deve à migração do epitélio gengival para a área de sulco e/ou à proliferação de tecido conjuntivo reconstruindo um novo tecido gengival.

Um estudo clínico de DONNENFELD; GLICKMAN ${ }^{12}$, em 1966, mostrou a formação das distâncias biológicas após gengivectomia em humanos. Foram utilizados 54 dentes anteriores superiores para medições da base do sulco gengival 
antes, logo após a cirurgia e com períodos de 1,2,4,8 e 12 semanas de pós-operatório. Também foi medida a largura da gengiva inserida. Todas as medidas foram feitas nas faces centrais dos dentes e com sonda calibrada de William. A junção cementoesmalte foi referência para medição do fundo da bolsa e da sua distância até a linha mucogengival. Como resultado, não houve mudança clínica ou estatisticamente significante na posição da base do sulco gengival após cicatrização e nem da posição da linha mucogengival.

Ainda em 1966, ENGLER; RAMFJORD; HINIKER ${ }^{13}$ realizaram um trabalho avaliando a dinâmica da reepitelização após gengivectomia em três macacos Rhesus. Foram feitas análise histológica e radioautográfica em biópsias colhidas no intervalo de 2 horas a 35 dias de pós-operatório. A resposta inicial foi necrose das margens e inflamação aguda do tecido conjuntivo. A migração e aumento da síntese de DNA nas células epiteliais começaram entre 12 e 24 horas após a cirurgia e alcançou um pico de atividade nas bordas da ferida entre 24 e $36 \mathrm{~h}$. A migração epitelial foi de 0,5mm por dia. A superfície estava completamente reepitelizada em 2 semanas e o sulco gengival se formou entre 3 e 5 semanas.

Numa continuação do trabalho anterior, no mesmo ano, RAMFJORD; ENGLER; HINIKER ${ }^{39}$ estudaram a cicatrização do tecido conjuntivo após gengivectomia. Com 2 horas de pós-operatório estava instalada uma inflamação aguda. O pico de proliferação celular foi aos 3 dias. A cicatrização do conjuntivo começou 0,3 a 0,5mm abaixo da superfície da ferida e somente se espalhou após completa epitelização. Houve demora de 21 a 35 dias para cicatrização completa da ferida e restauração da saúde gengival.

No ano de 1968 , STAHL et $\mathrm{al}^{49}$. estudaram as características clínicas e 
histológicas da cicatrização da mucosa oral após gengivectomia em humanos. Foram selecionados 218 dentes com bolsas supra-ósseas em 128 pacientes com doença periodontal. Foram obtidas 218 biópsias em intervalos de tempo de 0 a 28 dias de pós-operatório. A análise clínica foi feita por meio de fotografias. A análise histológica mostrou reepitelização completa dentro de 7 a 14 dias. Nesse estudo, a inflamação aumentou com o tempo, portanto, houve persistência de elementos celulares jovens no tecido e aumento do número de vasos. Não houve organização completa do tecido conjuntivo dentro dos 28 dias estudados. Paraceratinização estava presente na maioria das biópsias. Os autores citaram que o controle rigoroso de placa é fundamental para a cicatrização do tecido.

A técnica de perfusão intra-arterial de substâncias em cães foi utilizada por NOVAES et $\mathrm{aP}^{36}$. em 1969. Os autores queriam observar o desenvolvimento da microcirculação periodontal durante as fases de cicatrização após gengivectomia. Foram utilizados 8 cães jovens que receberam injeção intra-arterial de suspensão de carbono negro filtrado Pelikan nas artérias carótidas. A análise histológica foi feita de zero hora a 85 dias de pós-operatório. Como resultado, pôde-se observar que a vasodilatação e o aumento da vascularização diminuíram, à medida que a cicatrização evoluía, e atingiu aparência normal aos 16 dias. Também aos 16 dias o epitélio já havia recoberto toda a ferida e apresentava ceratinização e projeções epiteliais. De modo geral, a cicatrização consistiu na formação de uma nova lâmina própria derivada de uma camada vascularizada de tecido de granulação. A renovação epitelial ocorreu sobre esse tecido e a partir daí observou-se uma organização do tecido conjuntivo e maturação desse epitélio.

Nesse mesmo ano, HENNING ${ }^{20}$ estudou a cicatrização do epitélio gengival 
em 34 ratos pelo método da radioautografia. Os animais foram sacrificados com 30min, 2,4,12 e 24h e de 2 a 27 dias de pós-operatório. A atividade mitótica alcançou pico no intervalo de 24 e 48h e depois diminuiu até alcançar níveis normais com 12 dias. O epitélio recobriu a ferida em 5 dias. A atividade mitótica do epitélio juncional permaneceu elevada por 8 dias após a reepitelização da ferida.

Em 1970, INNES ${ }^{22}$ estudou a regeneração das estruturas gengivais em 14 cães pelo método da microscopia eletrônica. O período estudado foi de 0 a 14 dias. A migração epitelial teve início com 24 h após a cirurgia de gengivoplastia, sendo que a ferida estava totalmente reepitelizada com 5 dias e o epitélio sulcular organizado com 8 dias. Em áreas onde as células estavam em contato com a fibrina do coágulo, lâmina basal e hemidesmossomos se desenvolveram e o número de citofilamentos, desmossomos e ribossomos aumentou. As diferenciações para epitélio mastigatório foram: agrupamento dos citofilamentos nas células mais superficiais, aparecimento dos grânulos cerato-hialinos, estreitamento dos espaços intercelulares e formação do estrato córneo no sétimo dia. No epitélio que recobria o sulco gengival, os espaços intercelulares permaneceram alargados e as células superficiais desenvolveram um complexo de Golgi proeminente.

Outro estudo de microscopia eletrônica foi feito por LISTGARTEN ${ }^{29}$, em 1972, para avaliar a formação da junção dentogengival após gengivoplastia em macacos. Foi feita a remoção dos incisivos laterais de dois macacos, juntamente com o tecido gengival, em intervalos de 12 e 49 dias após a cirurgia. Houve formação do epitélio juncional com 12 dias e a união epitelial com o esmalte e cemento foi feita por meio de hemidesmossomos e lâmina basal. Os hemidesmossomos se regeneraram mais rápido que a membrana basal. $\mathrm{O}$ epitélio juncional não se 
regenerou enquanto o epitélio gengival não chegou próximo ao dente.

STAHL; TONNA ${ }^{50}$, em 1972, estudaram a atividade proliferativa das células da mucosa gengival e periodonto de sustentação após cirurgias de gengivectomia em 56 camundongos. A gengivectomia foi feita na papila mesial do primeiro molar esquerdo superior e o lado direito serviu como controle. Os animais foram mortos em grupos de quatro nos períodos de 1,8,16 horas, 1,2,4,6,8,e 16 dias, 1 e 3 meses. O epitélio alcançou pico de atividade proliferativa com 8 dias e manteve essa atividade por 30 dias. $\mathrm{O}$ epitélio juncional se formou em 4 dias e, junto com o epitélio do sulco, os fibroblastos adjacentes ainda exibiram elevada atividade até 1 mês. Os fibroblastos, osteoblastos e cementoblastos mostraram elevada atividade com dois dias de pós-operatório a qual retornou aos níveis de controle após 2 a 4 semanas.

No ano seguinte, AREMBAND; $\mathrm{WADE}^{4}$ realizaram um estudo comparativo da cicatrização de feridas de gengivoplastia feitas com bisturi elétrico e cirurgias convencionais. Foram escolhidos, para o estudo, 27 pacientes com necessidade de gengivectomia na região anterior superior e/ou inferior. Observações clínicas e fotográficas foram feitas com 1,2 e 3 semanas de pós-operatório. Foram feitas análises citológicas, histológicas e medidas do fluido gengival. As comparações clínicas e fotográficas não mostraram diferenças na cicatrização em ambos os lados. Em relação ao fluido gengival, na terceira semana, o lado operado pelo método convencional já havia atingido níveis de normalidade. A análise das camadas citológicas não mostrou diferença estatisticamente significante entre os grupos. O mesmo ocorreu com a análise histológica.

Em 1984, SABAG et $\mathrm{al}^{44}$. estudaram a formação do epitélio juncional após gengivectomia, em 30 ratos, por meio de microscopia de luz e microscopia 
eletrônica. A análise da cicatrização foi feita de 1 a 14 dias de pós-operatório. A análise microscópica mostrou formação de novo epitélio juncional no quinto dia e formação do complexo de união da lâmina basal com 8 dias. Hemidesmossomos e lâmina lúcida apareceram nas células epiteliais próximas da fibrina. Filamentos de ancoragem se formaram entre os hemidesmossomos e a fibrina subjacente a qual atravessou a lâmina lúcida. Simultaneamente, houve formação de lâmina densa e, aos 14 dias, houve completo desenvolvimento do complexo de união na lâmina basal do epitélio juncional.

\subsection{Laser}

Como o laser e suas características físicas e ópticas são um campo relativamente novo dentro da Odontologia, é pertinente que sejam feitas algumas explanações a respeito da física do laser, propriedades da luz e sua interação com os tecidos biológicos.

\subsubsection{Biofísica do Laser}

A maioria dos lasers é composta dos seguintes elementos ${ }^{34,65}$ : (FIGURA 1)

- Ressonador - trata-se de um tubo ou cavidade óptica com um arranjo de espelhos que amplificam os efeitos do laser. Um dos espelhos contidos na cavidade é de reflexão total e o outro de reflexão parcial.

- Meio ativo - determina o comprimento de onda da luz emitida. Pode ser sólido como o neodímio, érbio e os lasers semicondutores de arseneto de 
gálio e alumínio (GaAsAl) e arseneto de gálio (GaAs). Entre os meios ativos gasosos estão o argônio, hélio-neônio (He-Ne), dióxido de carbono $\left(\mathrm{CO}_{2}\right)$. Já os lasers líquidos são compostos de corantes orgânicos.

- Mecanismo de excitação ou bombeamento - consiste em uma fonte de energia externa que excita os eletrons do meio ativo. Pode ser uma descarga elétrica, o disparo de um flash e até uma ativação por outro laser.

$\mathrm{Na}$ natureza, os eletrons estão em estado de equilíbrio. Após estímulo por alguma energia externa, eles passam para um estado de excitação. Para voltar ao estado de equilíbrio, eles emitem um fóton, que é uma partícula de energia. Dentro do ressonador, esses fotons se propagam num eixo entre os dois espelhos e deixam a cavidade através do espelho semitransparente na forma de um feixe de luz.

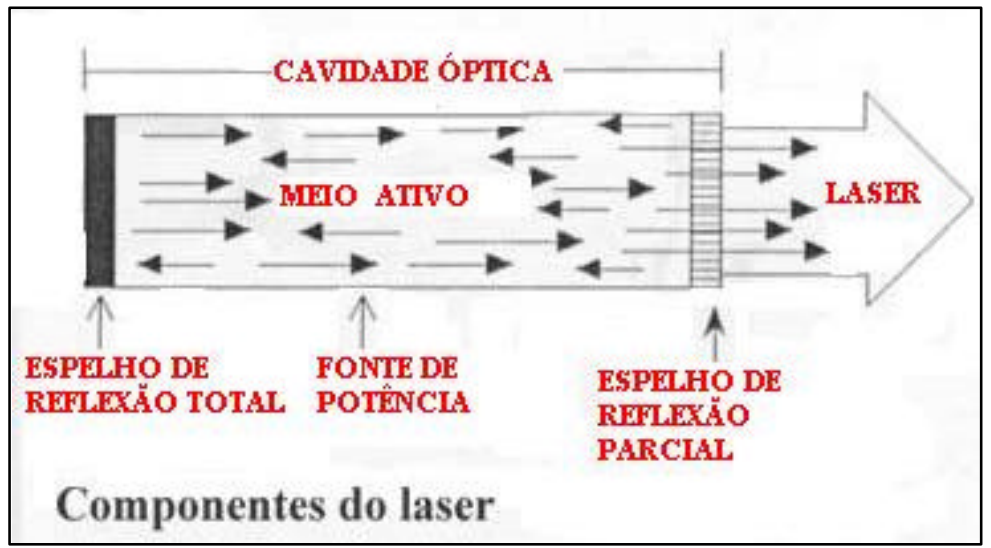

Adaptado de MISERENDINO, L.J.; PICK,R.M. ${ }^{34}$

FIGURA 1 - Componentes e mecanismo de funcionamento da maioria dos lasers

Essa luz possui propriedades únicas que a diferenciam da luz comum ${ }^{34,65}$ :

- Monocromaticidade - cada onda de luz tem exatamente o mesmo 
comprimento, ou seja, a mesma cor. É diferente da luz branca que pode se decompor em sete cores.

- Coerência - o feixe se propaga na mesma direção no tempo e no espaço e com a mesma freqüência.

- Colimação - a luz é unidirecional. Não há divergência do feixe de luz. Exemplos comuns são as ponteiras laser, que emitem um ponto com diâmetro constante, não importando a distância da tela. Já o feixe de uma lanterna aumenta seu diâmetro e diminui sua intensidade conforme a afastamos de uma parede.

Existem diferentes sistemas de entrega para que o laser chegue no tecido alvo. A luz pode passar através de lentes, microscópios, braços articulados e fibras ópticas. Estas últimas são mais comumente usadas na Odontologia, facilitando o acesso à boca $^{65}$.

Quando o laser atinge um tecido biológico, pode haver quatro tipos de interação ${ }^{34,65}$ (FIGURA 2) :

- Absorção - a luz é absorvida por componentes do tecido como a água, hemoglobina, melanina.

- Reflexão - parte da luz incidente é refletida e perdida.

- Espalhamento - parte da luz se espalha pelo tecido perdendo sua potência. $\mathrm{O}$ fenômeno do espalhamento pode ser visto ao acionar uma ponteira laser em contato com o dedo. Todo o dedo fica iluminado, mas a luz não o atravessa.

- Transmissão - a luz atravessa toda a espessura do tecido. 


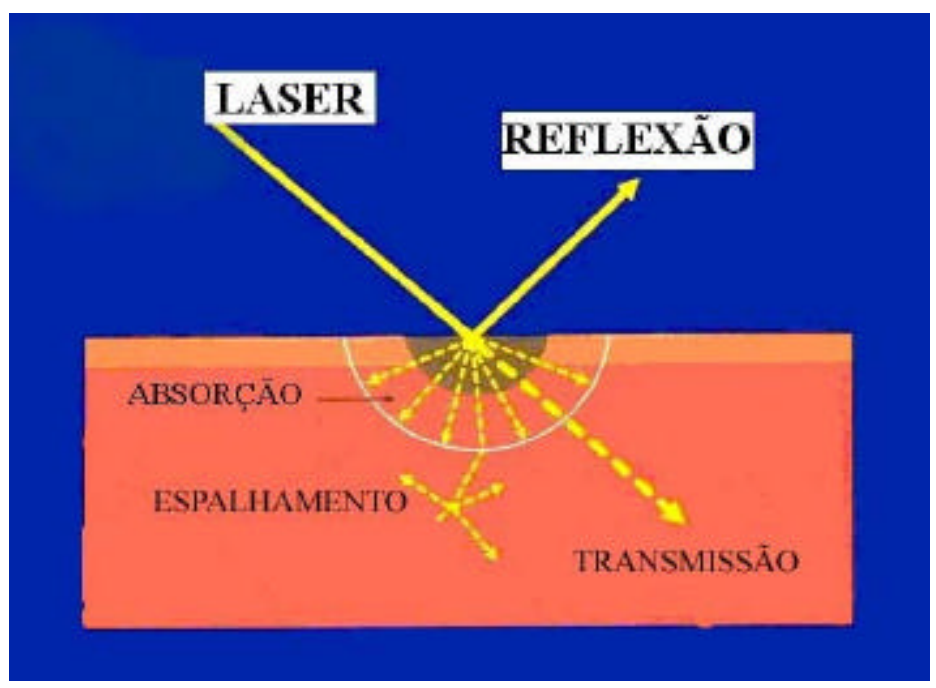

Adaptado de MISERENDINO, L.J.; PICK, R.M. ${ }^{34}$

FIGURA 2 - Tipos de interação do laser com os tecidos biológicos. A absorção é a mais desejada e a responsável pelos efeitos do laser no tecido.

Como os lasers são absorvidos por diferentes componentes do tecido, a exposição de algumas áreas do corpo pode ser danosa, principalmente os olhos. Os lasers são classificados pela ANSI (American National Standards Institute) de acordo com sua periculosidade $^{34}$. Essa classificação é baseada na potência de saída e comprimento de onda do laser e dividida em quatro classes ${ }^{34,65}$ :

- Classe 1 - lasers sem perigo, cuja potência não é percebida pelos olhos. Um exemplo é o leitor de CD.

- Classe 2 - lasers considerados perigosos apenas se alguém olhar diretamente para eles, e ainda assim o reflexo de piscar protege os olhos. Exemplo: leitor de código de barras.

- Classe 3a - lasers de média potência e perigosos se a luz for focalizada pelos olhos através de lentes ópticas. Exemplo: ponteiras laser. 
- Classe 3b - lasers de média potência e perigosos se forem vistos diretamente.

- Classe 4 - lasers de alta potência que podem causar dano ocular não apenas por contato direto, mas também quando refletidos. São danosos à pele e inflamáveis.

Os comprimentos de onda da luz visível e infravermelho (400 a 1400nm) são potencialmente perigosos para os olhos. Eles atravessam a córnea e o cristalino e causam danos na retina. A quantidade de perigo para a retina aumenta com a dilatação da pupila e com a duração do laser. Para evitar tais danos é obrigatório o uso de óculos de proteção durante a aplicação do laser pelo operador, paciente e toda a equipe. Existem óculos para cada tipo de laser, pois eles são capazes de filtrar comprimentos de onda específicos ${ }^{65}$.

\subsubsection{Lasers em baixa intensidade}

A terapia com lasers em baixa intensidade utiliza porções do espectro visível e infravermelho de luz. As primeiras pesquisas foram feitas com lasers de rubi, argônio e hélio-neônio que estão no espectro visível ${ }^{7,10,23,32,35,42}$. Mais recentemente, os lasers de diodo semicondutor de arseneto de gálio (GaAs) e arseneto de gálio e alumínio (GaAlAs) no espectro infravermelho têm se tornado mais populares 2,17, 26,28,30,31,46. (FIGURA 3). Inicialmente eram utilizados lasers com potências de até $1 \mathrm{~mW}$, mas com o desenvolvimento da tecnologia os aparelhos passaram a ter potências entre 10 a $90 \mathrm{~mW}$, o que diminuiu o tempo de aplicação 5 . 
O laser de hélio-neônio (He-Ne) é o mais antigo dos lasers e surgiu na década de 70. Emite ondas de luz no espectro visível, geralmente em torno de $630 \mathrm{~nm}$ (FIGURA 3 ).

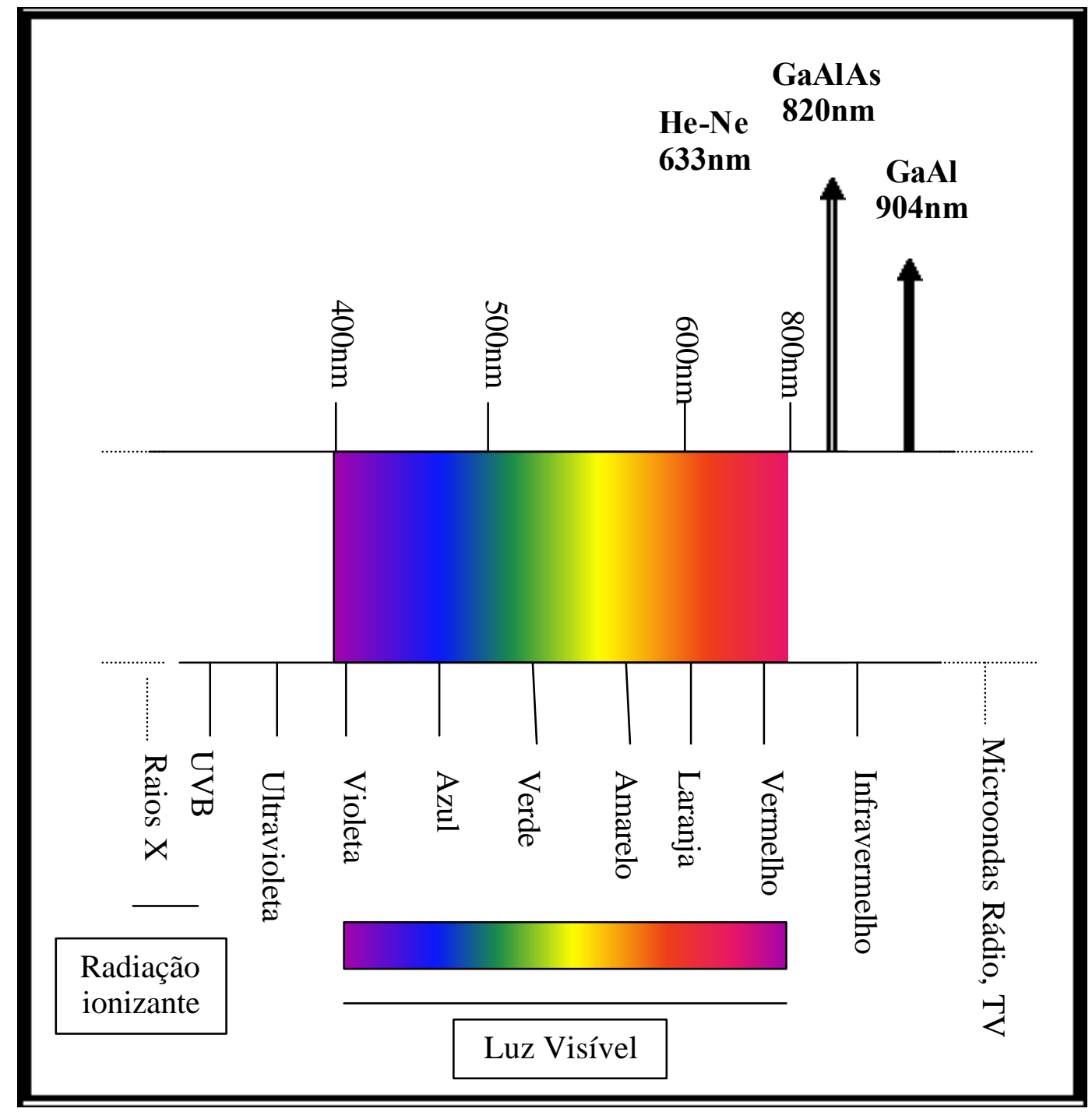

FIGURA 3 - Esquema mostrando o nível do espectro da luz onde se encontram os lasers em baixa intensidade.

Trabalha em modo contínuo, mas pode ser pulsado. Sua potência é de 1 a $10 \mathrm{~mW}$ e pode ser aplicado diretamente ou através de fibras ópticas. A profundidade de penetração é de 6 a 10mm, dependendo de sua potência ${ }^{54}$. 
O diodo semicondutor de arseneto de gálio (GaAs) surgiu na década de 80. Possui comprimento de onda de 904nm no espectro infravermelho (FIGURA 3) e usualmente trabalha no modo de pulsos. Devido ao modo pulsado penetra mais profundamente nos tecidos chegando a alcançar 30 a $50 \mathrm{~mm}^{54}$.

O diodo semicondutor de arseneto de gálio e alumínio (GaAlAs) tem comprimentos de onda de 780 a $870 \mathrm{~nm}$. Sua luz é invisível e está no espectro infravermelho (FIGURA 3). Alguns diodos GaAlAs possuem comprimento de onda no espectro vermelho, como o utilizado neste estudo. Seu modo de operação é contínuo na maioria dos aparelhos. A profundidade de penetração é de 20 a 30mm. Esse laser adquiriu muita popularidade nos anos 90 por ser um aparelho pequeno e leve e de custo razoável o qual utiliza potências de até $20 \mathrm{~mW}$. Também possui pontas intra-orais esterilizáveis com uma luz guia vermelha, pois o laser é invisíve ${ }^{54}$.

Os lasers de diodo (semicondutores) possuem o mecanismo de funcionamento um pouco diferente da maioria dos lasers. Eles consistem num "sanduíche" de pólos positivo e negativo, sendo a radiação emitida pelas laterais desse sanduíche. Se as faces laterais forem bem polidas perpendicularmente à saída do feixe, elas podem servir como os espelhos do ressonador. Isso faz com que esses aparelhos sejam bem compactos. A junção positiva/negativa de arseneto de gálio e alumínio é um diodo emissor de luz, o qual é levado à emissão laser pela passagem de uma alta corrente elétrica ${ }^{2}$.

Para que se obtenha a resposta biológica adequada é necessário atingir a dose ótima de radiação, o comprimento de onda correto e o número de aplicações suficientes para se produzir efeito. Os seguintes parâmetros devem ser observados: escolha do comprimento de onda, densidade de energia (dose ou fluência), densidade 
de potência (intensidade), tipo de regime de operação do laser e número de tratamentos. A potência do laser é o valor dado pelo fabricante em watts $(\mathrm{W})$. A densidade de potência é a potência de saída de luz por unidade de área medida em watts por centímetro quadrado $\left(\mathrm{W} / \mathrm{cm}^{2}\right)$. A densidade de energia, também chamada de dose, é a grandeza que avalia a possibilidade de estímulo ou inibição dos efeitos do laser. É a quantidade de energia por unidade de área transferida ao tecido. Geralmente é expressa em joules por centímetro quadrado $\left(\mathrm{J} / \mathrm{cm}^{2}\right)^{40}$.

Das propriedades da luz laser, a colimação não parece ser crucial para causar os efeitos do laser visto que é rapidamente degradada ao passar pelos tecidos (efeito de espalhamento). A monocromaticidade parece ser vital, pois os efeitos nas células são causados por comprimentos de onda de uma estreita faixa do espectro da luz. Os lasers em baixa intensidade estão numa faixa do espectro que não é absorvida por muitos componentes do organismo e, por isso, possuem maior profundidade de penetração. Comprimentos de onda mais longos são mais resistentes ao espalhamento e penetram mais nos tecidos. A luz vermelha do laser de $\mathrm{He}-\mathrm{Ne}$ penetra 0,5 a $1 \mathrm{~mm}$ antes de perder $37 \%$ de sua intensidade, enquanto que a luz infravermelha do laser de GaAlAs penetra mais de $2 \mathrm{~mm}$ antes de perder a mesma quantidade de energia. A terapia a laser envolve usualmente exposições de $4 \mathrm{~J} / \mathrm{cm}^{2}$, o que significa uma penetração de 0,5 a $2,5 \mathrm{~cm}$ podendo atingir até nervos, músculos e articulações 5 .

Os mecanismos biomoleculares da ação do laser em baixa intensidade são bem diferentes dos mecanismos térmicos do laser de alta potência. O evento inicial que ocorre é a absorção da luz por moléculas do tecido alvo as quais são chamadas de cromóforos. Outras moléculas fotossensitivas são a clorofila na fotossíntese, a 
rodopsina na visão. Os citocromos são enzimas da cadeia respiratória e estão presentes nas mitocôndrias das células. São responsáveis por converter ADP em ATP, que fornece energia para a célula e dirige o seu metabolismo (síntese de proteínas, replicação, motilidade celular, manutenção do potencial da membrana). Como os citocromos são fotossensíveis, a energia do laser é absorvida e convertida em energia para a célula (ATP) $)^{19,27,34,61}$.

A ação dos lasers em baixa intensidade nos tecidos ocorre dentro de um espectro limitado da luz de comprimentos de onda de 600 a $900 \mathrm{~nm}$ os quais possuem níveis de energia e absorção relevantes para a cadeia respiratória ${ }^{61}$. No espectro entre 500 e $1200 \mathrm{~nm}$, não há uma molécula específica que absorva toda energia do laser. Como exemplo, a hemoglobina e melanina interagem com comprimento de onda de $500 \mathrm{~nm}$ do laser de argônio. Toda energia é absorvida por esses pigmentos e a luz não atinge outras áreas do tecido. Já a água, interage com o laser de $\mathrm{CO}_{2}$ no espectro de $10.000 \mathrm{~nm}$. Esse intervalo de 500 a 1200nm é chamado de "janela óptica" dos tecidos. Por não haver moléculas de absorção específica para esses comprimentos de onda, o tecido permite a livre passagem e espalhamento dos raios vermelhos e infravermelhos dos lasers em baixa intensidade até que cheguem aos citocromos das mitocôndrias ${ }^{19,27,34,61}$.

$\mathrm{KARU}^{24}$ propôs um modelo de estimulação dos sistemas biológicos para a luz visível (vermelha). A luz promove mudanças fotoquímicas nos receptores das mitocôndrias, alterando o metabolismo. Há envio dos sinais para outras áreas da célula e geração da fotoresposta.

$\mathrm{SMITH}^{47}$ sugeriu o mecanismo de ação para a luz infravermelha. Devido a suas propriedades fotofísicas e fotoquímicas, ela inicia a cascata de eventos 
metabólicos através de efeitos fotofísicos nas membranas, agindo nos canais de cálcio. Apesar de efeitos diferentes, a resposta final é a mesma ${ }^{40}$ (FIGURA 4 ) .

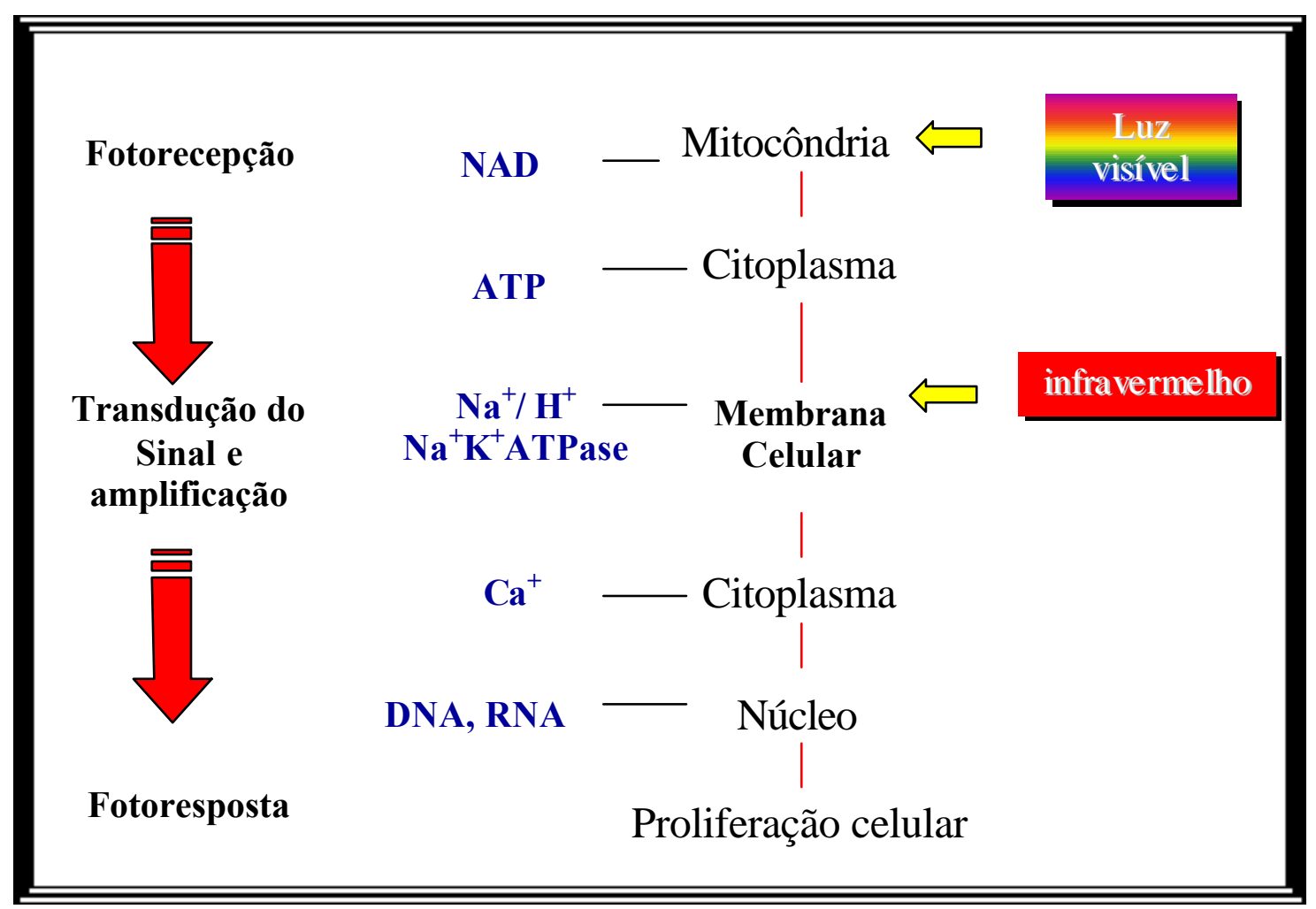

Adaptado de SMITH, K. ${ }^{47}$

FIGURA 4- Modelos para estimulação dos sistemas biológicos pelo laser em baixa intensidade.

Nenhum efeito colateral foi observado com o uso de lasers no espectro vermelho e infravermelho, pois seus fotons são de baixa energia e não causam ionização. Causam somente excitação e calor. Já os raios UVB e raios X estão no espectro abaixo do ultravioleta (FIGURA 3). Estes possuem fotons de alta energia e podem ionizar átomos, partindo suas ligações químicas e causando mutações ${ }^{54}$.

\subsubsection{Laser em baixa intensidade na cicatrização de feridas}


Os trabalhos que relatam a utilização do laser em baixa intensidade para cicatrização de feridas cutâneas, na maioria, são da área médica. Como a cicatrização da mucosa oral é semelhante à da pele, todos estes trabalhos foram considerados nesta revisão da literatura.

MESTER et al., em 1969, apud MESTER; MESTER; MESTER ${ }^{33}$, em 1985, fizeram uma análise microscópica dos efeitos do laser de rubi na cicatrização de feridas no dorso de camundongos. O laser foi aplicado com dose de $1,1 \mathrm{~J} / \mathrm{cm}^{2}$, duas vezes por semana, totalizando 4 sessões. Os efeitos observados foram aumento da atividade celular nas bordas e base da ferida, aumento na divisão celular com formação mais rápida de tecido de granulação. Clinicamente, houve fechamento mais rápido na ferida do lado teste.

MESTER et al. ${ }^{32}$, em 1971, analisaram fotográfica e histologicamente os efeitos do laser de rubi (694,3 nm - vermelha) em feridas mecânicas e queimaduras de terceiro grau feitas no dorso de camundongos. O laser foi utilizado no modo de pulsos e com doses de 1,4 e $5 \mathrm{~J} / \mathrm{cm}^{2}$, duas vezes por semana, perfazendo um total de seis sessões. Um lado dos animais foi utilizado para controle e o outro foi irradiado. O período avaliado foi de 7 a 14 dias. O melhor efeito na aceleração da cicatrização foi obtido com $1,1 \mathrm{~J} / \mathrm{cm}^{2}$, tanto para as feridas mecânicas quanto para as queimaduras. No sétimo dia, a ferida cirúrgica do lado teste tinha metade do tamanho do lado controle e, com 14 dias, estava completamente fechada.

Em 1974, MESTER et al. apud MESTER; MESTER; MESTER ${ }^{33}$, em 1985, fizeram um trabalho em humanos utilizando o laser de He-Ne para tratamento de úlceras persistentes com as mais variadas etiologias, as quais não respondiam a 
tratamento convencional. O laser foi aplicado com dose de $4 \mathrm{~J} / \mathrm{cm}^{2}$ duas vezes por semana . A cicatrização demorou 12 a 16 semanas. Dos 970 casos tratados com laser, 875 obtiveram cura, 160 obtiveram melhora e apenas 85 não responderam ao tratamento.

Em 1981, KANA et al. ${ }^{23}$ compararam os efe itos do laser de $\mathrm{He}-\mathrm{Ne}(632,8 \mathrm{~nm}$ - vermelha) e argônio (514,5 nm - verde) na cicatrização de feridas mecânicas no dorso de ratos. $\mathrm{O}$ estudo utilizou 12 grupos com 8 animais cada, que foram irradiados diariamente durante 17 dias com dosagens de 4, 10 e $20 \mathrm{Jcm}^{2}$. Foram feitas duas feridas e uma delas serviu de controle. Um grupo de animais não irradiados serviu como controle independente. As feridas foram fotografadas e a evolução da cicatrização foi avaliada planimetricamente. A quantidade de colágeno foi medida no $18^{\circ}$ dia por métodos bioquímicos. Entre o $3^{\circ}$ e $12^{\circ}$ dia, o fechamento da ferida no grupo irradiado com He-Ne $4 \mathrm{~J} / \mathrm{cm}^{2}$ foi mais acelerado e a produção de colágeno foi maior. Houve uma certa desaceleração no processo cicatricial com as dosagens de $20 \mathrm{~J} / \mathrm{cm}^{2}$, para ambos os lasers, sugerindo que altas dosagens podem ter efeito contrário ao esperado. O laser de argônio não provocou diferenças significantes em nenhuma das dosagens, talvez por provocar um efeito sistêmico na área ou pelo fato de as células epiteliais responderem mais favoravelmente à luz vermelha.

Um artigo de revisão da literatura da época, publicado em 1988 por STRANG et al. ${ }^{52}$, confrontou trabalhos em que a terapia com laser em baixa intensidade produziu aceleração da cicatrização de feridas cutâneas, com outros onde não houve alterações significantes nos tecidos. A discussão mostrou que há falta de padronização dos estudos. Existe grande variação na escolha do modelo animal, tipo 
e tamanho da ferida cirúrgica, método de análise do efeito do hser. E, ainda, muitos artigos não trazem informações fundamentais como potência utilizada, modo de pulsos ou contínuo e duração da exposição.

BRAVERMAN et al. $^{6}$, em 1989, avaliaram os efeitos do laser de $\mathrm{He}-\mathrm{Ne}$ (632,8 nm vermelho) e do laser GaAsAl (904 nm - infravermelho) na reparação tecidual em coelhos. Foram utilizados 72 animais divididos em quatro grupos: controle, laser He-Ne em modo contínuo, laser GaAlAs em modo de pulsos, e ambos os lasers juntos. O grupo do laser $\mathrm{He}-\mathrm{Ne}$ recebeu dose de $1,65 \mathrm{~J} / \mathrm{cm}^{2}$ e o do laser infravermelho, $8,25 \mathrm{~J} / \mathrm{cm}^{2}$. No grupo que recebeu os dois lasers, as doses foram somadas. Medidas do fechamento da ferida foram feitas através de fotografias tiradas desde 1 até 21 dias de pós-operatório. Foi feita análise histológica para medição da espessura epidermal e deposição geométrica do colágeno. Nessas análises, não houve diferença estatisticamente significante entre os lados teste, controle e grupo controle isolado para ambos os lasers. A força de tensão do tecido foi analisada e buve maior resistência à tensão nos grupos tratados em relação ao grupo controle. Essa diferença foi estatisticamente significante apenas dos grupos teste para o grupo controle e não para diferentes lados num mesmo animal, sugerindo a liberação de algum fator na circulação causador de efeito sistêmico.

Os efeitos sistêmicos do laser de $\mathrm{He}-\mathrm{Ne}(632,8 \mathrm{~nm})$ na cicatrização de feridas cutâneas, queimaduras e regeneração nervosa foram estudados por ROCHKIND et al. ${ }^{42}$ em 1989. A pesquisa foi realizada em ratos e para cada análise havia um lado teste e controle no mesmo animal e grupo controle individualizado. O laser foi aplicado durante 21 dias e a dose variou de 7,6 a $10 \mathrm{~J} / \mathrm{cm}^{2}$. No grupo onde foram feitas feridas cutâneas, houve cicatrização mais rápida no lado onde o laser foi 
aplicado. O lado oposto (controle) estava mais bem cicatrizado que o grupo controle isolado que não foi irradiado. A avaliação da cicatrização de queimaduras também obteve resultados positivos. O lado esquerdo (controle) demorou mais a cicatrizar, porém não tinha os sinais de gangrena e necrose presentes no grupo não irradiado. $\mathrm{O}$ laser não causou efeito no potencial de ação de nervos intactos, porém em nervos lesados por compressão houve um efeito prolongado da ação no grupo irradiado. O potencial de ação do nervo após um ano chegou a 133\% do potencial inicial, sendo que no grupo não irradiado o valor chegou apenas a 67\%. Finalmente, a análise histológica da corda espinhal correspondente ao nervo lesado mostrou degeneração nos nervos motores m grupo não tratado e normalidade no grupo teste. Os autores sugerem que os efeitos sistêmicos do laser podem ocorrer pelo aumento da capacidade de fagocitose dos leucócitos no caso das feridas cutâneas, e a regeneração nervosa pode ser estimulada pela liberação de fatores de crescimento. Porém esse mecanismo é apenas uma hipótese.

Em 1990, CARRILLO et al. ${ }^{7}$ avaliaram a eficácia do laser He-Ne $(632,8$ nm) na redução do edema, dor e trismo após extração de terceiros molares não irrompidos em 100 pacientes. O grupo do laser foi comparado com um grupo placebo para o laser e com um grupo que recebeu antiinflamatório (Ibuprofeno). O laser foi aplicado em 6 pontos no local da cirurgia com uma dose de $10 \mathrm{~J} / \mathrm{cm}^{2}$. Houve redução significante do trismo no grupo laser e ibuprofeno, mas sem diferenças entre eles. A dor foi menor no grupo que recebeu antiinflamatório e o edema foi semelhante nos três grupos.

Um estudo dos efeitos do laser de GaAlAs (830nm) na cicatrização de feridas no palato de cães foi feito por IN de BRAEKT et al. ${ }^{21}$ em 1991. Levantou-se um 
retalho total no palato deixando-se a superfície óssea exposta em dois grupos experimentais. O grupo controle não foi operado. O laser foi aplicado em um dos grupos teste, em 4 pontos da ferida com dose total de $1 \mathrm{~J} / \mathrm{cm}^{2}, 3$ vezes por semana, totalizando 10 sessões. $\mathrm{O}$ outro grupo teste operado não recebeu nenhum tratamento. A avaliação clínica foi feita por meio de fotografias no período de 0 a 13 semanas. Seis pontos de tatuagem foram marcados ao longo das bordas da ferida para medição da contração nos grupos operados e no grupo controle não operado. Não houve diferenças estatisticamente significantes entre os grupos teste em relação à cicatrização, crescimento epitelial e conjuntivo das margens da ferida. Os resultados sobre contração da ferida mostraram diferenças significantes apenas entre o grupo operado que não recebeu laser e o grupo controle não operado.

MESTER; MESTER; MESTER ${ }^{33}$ publicaram, em 1985, um artigo de revisão de seus trabalhos com laser em baixa intensidade. Relatam as experiências de 20 anos de uso do laser em diversos sistemas biológicos, mostrando que há um efeito estimulante sobre as células. Estudos com microscopia eletrônica mostraram um aumento de fibras colágenas e presença de vesículas relacionadas à produção de colágeno. Medindo a atividade celular, concluíram que o laser afeta a fase colagênica da cicatrização de feridas. Outros efeitos observados foram aumento da produção de vasos sangüíneos, síntese de DNA e RNA a qual pode ser percebida pelo número de mitoses no tecido. E, finalmente, o laser é capaz de aumentar a produção de prostaglandinas E e F, o que contribui para a aceleração da cicatrização.

Em 1987, CHOMETTE et al. ${ }^{9}$ apud TUNÉR; HODE ${ }^{54}$, em 1996, estudaram os efeitos do laser de He-Ne em fibroblastos humanos a partir de biópsias realizadas na mucosa bucal após 15min, $1 \mathrm{~h}$ e $3 \mathrm{~h}$ da irradiação. Biópsias controle foram 
realizadas em locais distantes ao sítio irradiado. Atividades enzimáticas dos fibroblastos foram medidas após $24 \mathrm{~h}$ e estavam aumentadas. Através de microscopia eletrônica de varredura observaram-se aumento das organelas citoplasmáticas e aumento da produção de colágeno. Essas diferenças foram significantes em relação ao grupo controle.

Os mesmos autores, ainda em 1994, fizeram uma análise da cicatrização gengival em 14 pacientes. Foi realizada uma biópsia na área irradiada com laser HeNe e outra da área não irradiada que serviu como controle. Tanto em pacientes que possuíam gengivite, quanto em pacientes com gengiva clinicamente saudável, a cicatrização foi mais rápida para o lado teste, demorando 14 dias para estar completa, enquanto que no lado controle, demorou 21 dias $^{8}$.

SOUDRY et al. ${ }^{48}$, em 1988, realizaram uma pesquisa in vitro dos efeitos do laser de He-Ne em cultura de fibroblastos gengivais humanos. Foi utilizado o laser de $\mathrm{He}-\mathrm{Ne}(632,8 \mathrm{~nm})$ por vários dias e com dose de 1,2 $\mathrm{J} / \mathrm{cm}^{2}$. Houve aceleração do crescimento celular em relação ao grupo controle e o melhor efeito foi obtido com 4 dias de tratamento.

Os efeitos analgésicos do laser de $\mathrm{He}-\mathrm{Ne}(632,8 \mathrm{~nm})$ após extração de terceiros molares em humanos foram estudados por CLOKIE; BENTLEY; HEAD ${ }^{10}$ em 1991. O laser foi aplicado com dose de $5,4 \mathrm{~J} / \mathrm{cm}^{2}$ em modo de varredura na área operada. Um lado foi usado como teste e o outro recebeu placebo. Dos 15 pacientes estudados, $60 \%$ teve menor dor no lado teste, $20 \%$ no lado controle e em $20 \%$ ambos os lados foram semelhantes. Com relação ao edema, a maioria (46,7\%) não mostrou diferenças entre os lados, $26,7 \%$ teve edema maior no lado teste e $26,7 \%$ no lado controle. 
Em 1993, FERNANDO; HILL; WALKER ${ }^{14}$ utilizaram um laser semicondutor $(830 \mathrm{~nm})$ após cirurgias de extração de terceiros molares. Foram analisados 64 pacientes. Em um dos lados, o laser foi aplicado dentro do alvéolo com dose de $4 \mathrm{~J} / \mathrm{cm}^{2}$ e, no outro, foi aplicado um placebo. As análises de dor, edema e cicatrização da área não mostraram diferenças significantes.

STEINLECHNER; DYSON, em 1993, apud TUNÉR; HODE, em 1996, estudaram os efeitos do laser de He-Ne e GaAs na proliferação de ceratinócitos. Um dos grupos foi cultivado em ambiente pobre em nutrientes (1\% soro fetal) e outro em ambiente rico (5\% soro fetal). A terapia com laser em baixa intensidade causou maior aumento na proliferação de ceratinócitos cultivados no ambiente pobre em nutrientes.

Num estudo de cicatrização de feridas em ratos, HALL et al. ${ }^{18}$, em 1994, não obtiveram resultados significantes com o uso do laser de GaAlAs (904nm). Os ratos foram divididos em grupo teste onde apenas um lado era irradiado com o laser. O grupo controle teve um dos lados exposto à luz normal. A dose de laser aplicada foi de $0,2 \mathrm{~J} / \mathrm{cm}^{2}$ diariamente, de 0 a 21 dias de pós-operatório. Observações clínicas e histológicas foram semelhantes para ambos os grupos.

No mesmo ano, LOEVSCHALL; ARENHOLT-BINDSLEV ${ }^{30}$ realizaram um trabalho in vitro com cultura de fibroblastos da mucosa oral de humanos. O laser de GaAlAs (812nm) foi aplicado uma vez com doses de 4,5 a $4500 \mathrm{~mJ} / \mathrm{cm}^{2}(0,004$ a 4,5 $\mathrm{J} / \mathrm{cm}^{2}$ ). Após a aplicação, trimidina tritiada foi incorporada à cultura. Não houve mudanças morfológicas nem na viabilidade das células após a irradiação, mas a incorporação de trimidina tritiada foi mais alta em alguns grupos, o que significa um aumento da síntese de DNA. O grupo que mostrou melhores resultados fi o que 
recebeu $0,45 \mathrm{~J} / \mathrm{cm}^{2}$.

Ainda em 1994, RYDÉN et al. ${ }^{43}$ estudaram os efeitos do laser na redução da inflamação gengival em humanos. Foi provocada gengivite experimental em 10 mulheres após 21 dias sem higienização. Após esse período, foi feita profilaxia profissional e foram retomados os hábitos de higiene. O laser foi aplicado a cada 3 dias durante 6 dias com dose de $0,5 \mathrm{~J} / \mathrm{cm}^{2}$. O lado oposto do próprio paciente foi considerado como controle. Não houve diferenças estatisticamente significantes entre os lados com relação ao acúmulo de placa e índice de sangramento gengival. A análise estereofotográfica da reação vascular, que quantifica a reação inflamatória, também não mostrou diferenças significantes entre os grupos.

Num estudo in vitro, em 1994, YU et al. ${ }^{62}$ investigaram a produção do fator de crescimento transformador (TGF $\beta_{2}$ ) e do fator derivado de plaquetas (PDGF) de fibroblastos irradiados com laser em vários comprimentos de onda: 630, 640, 650, 660nm. Todos os valores testados provocaram aumento significante em relação ao controle. Os autores concluíram que o laser modula a liberação de TGF $\beta$ e PDGF pelos fibroblastos e sugerem que a bioestimulação pelo laser pode estar associada à regulação das células via produtos autócrinos dos diferentes fatores de crescimento.

CONLAN; RAPLEY; COBB ${ }^{11}$, em 1996, fizeram uma revisão da literatura a respeito da bioestimulação da cicatrização de feridas. Foram analisados vários trabalhos sobre efeitos do laser na proliferação de fibroblastos, síntese de colágeno, mecanismo de ação do laser e reparo de feridas em animais e humanos. Concluíram que há trabalhos mostrando tanto resultados positivos quanto negativos dos efeitos do laser e seu mecanismo de ação sobre as células não está esclarecido devido à grande variação entre os parâmetros de aplicação. Os autores não encorajam a terapia 
laser em humanos por falta de estudos convincentes e controlados.

Ainda em 1996, SKINNER et al. ${ }^{46}$ investigaram a produção de procolágeno e divisão celular em culturas de fibroblastos embrionários humanos, estimuladas pelo laser GaAs $(904 \mathrm{~nm})$. Foram aplicadas doses de 0 a $1 \mathrm{~J} / \mathrm{cm}^{2}$ durante 4 dias. Houve um pico na síntese de colágeno e replicação do DNA, após 4 sessões diárias, com doses de 0,099 e $0,522 \mathrm{~J} / \mathrm{cm}^{2}$. Fibroblastos em estágio embrionário respondem melhor aos estímulos do laser em baixa potência.

No ano seguinte, WALSH$^{57}$ publicou uma revisão de trabalhos sobre a terapia com laser em baixa intensidade. Foram discutidos estudos sobre os efeitos do laser em fibroblastos, células de defesa, células epiteliais, células ósseas, sistema circulatório, cicatrização de feridas, dor, regeneração nervosa e doenças inflamatórias como sinusite e gengivite. Sua conclusão foi otimista em relação às pesquisas in vitro. Mas sugere que para que o uso clínico dos lasers seja difundido há necessidade da criação de protocolos padronizados, trabalhos mais controlados e maior divulgação dos resultados.

Tendo como princípio que células não saudáveis respondem melhor aos estímulos com laser, YU; NAIM; LANZAFAME ${ }^{63}$, em 1997, fizeram um estudo em ratos diabéticos. Os animais foram divididos em quatro grupos, sendo um controle, um que recebeu fator de crescimento derivado de fibroblastos (FGF) tópico, um que recebeu laser de argônio $\left(630 \mathrm{~nm}-5 \mathrm{~J} / \mathrm{cm}^{2}\right)$ e o último onde foi aplicado laser associado ao FGF tópico. Os tratamentos foram aplicados diariamente durante 4 dias. O laser teve efeito significante na cicatrização das feridas em relação ao grupo controle. Entre os grupos teste não houve diferenças estatisticamente significantes.

Um estudo in vitro para avaliar a ação do laser na proliferação de 
ceratinócitos humanos foi feito por GROSSMAN et al. ${ }^{17}$ em 1998. A proliferação celular foi medida através da incorporação de timidina tritiada de 6 a 24h após

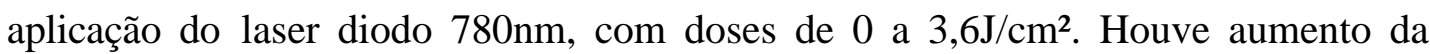
proliferação celular com doses de 0,45 a $0,95 \mathrm{~J} / \mathrm{cm}^{2}$. Doses mais baixas não afetaram as amostras.

LOWE et al. ${ }^{31}$, em 1998, estudaram os efeitos do laser de GaAlAs 890nm, com doses variadas, na cicatrização de feridas pós-radiação com dose alta de raios X. Foram utilizados 5 grupos de camundongos, sendo que o primeiro não foi irradiado, dois grupos foram irradiados com raios X-20Gy e três grupos receberam o raio X mais irradiação laser 3 vezes por semana, com doses de 0,$18 ; 0,54$ e $1,45 \mathrm{~J} / \mathrm{cm}^{2}$. A radiação com raios $\mathrm{X}$ efetivamente atrasou a cicatrização das feridas em relação ao grupo controle. Nos grupos tratados com laser não houve aceleração da cicatrização, sendo que o grupo que recebeu $1,45 \mathrm{~J} / \mathrm{cm}^{2}$ teve atraso por volta do $16^{\circ}$ dia em comparação com os outros grupos.

No mesmo ano, WEBB; DYSON; LEWIS ${ }^{58}$, num estudo in vitro, avaliaram os efeitos do laser diodo 660nm na proliferação celular de fibroblastos humanos normais em comparação com fibroblastos oriundos de tecido hipertrófico de cicatriz de pele. O laser foi aplicado com doses de 2,4 e $4 \mathrm{~J} / \mathrm{cm}^{2}$. Houve um aumento significante na contagem de fibroblastos oriundos do tecido hipertrófico no grupo que recebeu $2,4 \mathrm{~J} / \mathrm{cm}^{2}$. Os autores sugeriram que a luz pode ter induzido a secreção de fatores de crescimento, que aumentaram as taxas de mitose e/ou reduziram a morte celular.

Em 1999, NEIBURGER ${ }^{35}$ avaliou a cicatrização de feridas após extração dentária irradiadas com laser de He-Ne 670nm. Para esse estudo, utilizou 58 
pacientes que necessitaram de extração dentária com levantamento de retalhos. $\mathrm{O}$ laser foi aplicado em uma das incisões relaxantes (mesial ou distal) com $0,34 \mathrm{~J} / \mathrm{cm}^{2}$ apenas uma vez. A outra incisão relaxante serviu como controle. A avaliação foi feita clinicamente e por meio de fotografias por 3 cirurgiões-dentistas. Como resultados, $69 \%$ das incisões tiveram melhor cicatrização no lado teste, $7 \%$ tiveram ambos os lados iguais e, em 14\% das incisões, o lado controle teve melhor cicatrização.

SAKURAI; YAMAGUCHI; $\mathrm{ABIKO}^{45}$, em 2000, fizeram uma pesquisa in vitro verificando os efeitos do laser GaAlAs 830nm na produção de prostaglandina E2 (PGE2) por fibroblastos gengivais humanos. As células foram colocadas em contato com lipopolissacarídeos bacterianos para que a produção da PGE2 fosse estimulada. O laser foi aplicado com doses de 0,95 a $6,32 \mathrm{~J} / \mathrm{cm}^{2}$. A irradiação com laser inibiu a produção da PGE2 de forma dose dependente. Após 10min de irradiação, houve inibição de $90 \%$ da sua produção e, após 20 min, sua produção estava no nível controle. O mecanismo pelo qual a produção da PGE2 foi reduzida também foi estudado. Os autores chegaram à conclusão de que há uma redução da expressão do gene Ciclooxigenase 2 (COX2) que regula a produção de prostaglandinas.

Num estudo semelhante ao de 1998, realizado pelo mesmo grupo, WALKER et al. ${ }^{56}$, em 2000, avaliaram os efeitos do laser GaAlAs $660 \mathrm{~nm}$ na cicatrização de feridas em ratos. Os animais receberam altas doses de radiação $\mathrm{X}$ e depois foram feitas feridas no dorso, as quais foram medidas até seu completo fechamento. Em três grupos teste foram aplicadas doses de 0,$5 ; 1,5$ e $4 \mathrm{~J} / \mathrm{cm}^{2}$ do laser três vezes por semana. O grupo controle não foi irradiado. Não houve resultado significante na aceleração da cicatrização das feridas. 
LAGAN et al. ${ }^{28}$, em 2001, observaram os efeitos do laser GaAlAs 830nm na cicatrização de feridas humanas após cirurgias de remoção parcial e total das unhas em estado agudo de inflamação. O laser foi aplicado com $9 \mathrm{~J} / \mathrm{cm}^{2}$ de potência em 3 pontos por ferida. Os aspectos clínicos da cicatrização foram avaliados e foram feitas medidas do tamanho da ferida. Também foi avaliada a dor dos pacientes. O laser não foi eficiente em controlar nenhum dos parâmetros avaliados.

Em 2001, AMORIM ${ }^{2}$ avaliou a reparação gengival após cirurgia de gengivoplastia em humanos estimulada pelo laser de GaAlAs (685nm). Um dos lados do paciente serviu como controle e o outro recebeu aplicações de $4 \mathrm{~J} / \mathrm{cm}^{2}$ imediatamente após a cirurgia e com 1, 3 e 7 dias de pós-operatório. Foi feita uma avaliação clínica da cicatrização por três periodontistas e avaliação biométrica das feridas. A avaliação clínica mostrou melhora na reparação tecidual no lado teste após 3 dias de pós-operatório. Na avaliação biométrica, as medidas de profundidade de sondagem foram significantes para o lado teste. Já as medidas de mudança na posição da margem gengival e espessura da faixa de mucosa ceratinizada não foram significantes entre os lados.

KREISLER et al. ${ }^{26}$, em 2002, investigaram os efeitos do laser GaAlAs 890 nm na taxa de proliferação de fibroblastos humanos gengivais em cultura, com diferentes doses de energia. Foram aplicadas doses de 1,$96 ; 3,92 ; 7,84 \mathrm{~J} / \mathrm{cm}^{2}$ a cada $24 \mathrm{~h}$ durante dois ou três dias. Em todos os grupos teste houve maior atividade celular em relação aos controles. Houve pico de atividade após 24 horas e depois houve um decréscimo até o terceiro dia. Os autores sugeriram que a proliferação de fibroblastos pode estar associada a uma produção autócrina de fatores de crescimento. 
Ainda em 2002, ANDERS et al. $^{3}$ avaliaram a produção de fator de crescimento derivado de fibroblastos (FGF) estimulada pelo laser em baixa intensidade em ratos normais e diabéticos. Foram feitas feridas cutâneas no dorso dos ratos e uma das feridas serviu como controle. O laser utilizado foi um diodo de 632,8 $\mathrm{nm}$ com $4 \mathrm{~J} / \mathrm{cm}^{2}$ de densidade de potência, diariamente, durante 3 dias. Houve diferença estatisticamente significante para a produção de FGF tanto entre lados controle e tratados quanto entre os ratos diabéticos e não diabéticos. Os autores sugeriram que a produção de FGF é confinada à área irradiada, já que no lado controle não houve mudanças. 
3 PROPOSIÇÃO 


\section{PROPOSIÇÃO}

A proposta deste estudo foi avaliar, clinica e histologicamente, a influência do laser em baixa intensidade no processo cicatricial, em humanos, após gengivoplastia, comparando a áreas cirúrgicas não irradiadas e irradiadas, durante o período experimental de 7 a 60 dias. 
4 MATERIAL E MÉTODOS 


\section{MATERIAL E MÉTODOS}

\subsection{Seleção dos pacientes}

Foram selecionados 13 pacientes que procuraram tratamento na Faculdade de Odontologia de Bauru - USP, sem distinção de idade e gênero, os quais possuíam hiperplasia gengival inflamatória na região de canino a canino superior e/ou inferior. A idade dos pacientes selecionados variou de 13 a 40 anos. Cada arcada foi considerada isoladamente perfazendo um total de 18 áreas a serem tratadas.

Os critérios de exclusão considerados para este estudo foram: pacientes com alterações sistêmicas que contra-indicassem o ato cirúrgico ou que prejudicassem a cicatrização, bem como uso de medicamentos que pudessem interferir no processo cicatricial; mulheres gestantes, indivíduos com história prévia de hemorragia, etilistas, fumantes e pacientes com diagnóstico de hiperplasia gengival medicamentosa.

Entre os critérios de inclusão foram considerados: presença de todos os dentes na área a ser tratada; hiperplasias gengivais inflamatórias na área de interesse que não regrediram com raspagem, alisamento coronário e controle de placa; ausência de perdas ósseas na área a ser tratada.

\subsection{Aspectos éticos}

Os critérios estabelecidos para a execução deste estudo estão de acordo com as normas da resolução 196 do Conselho de Saúde do Ministério da Saúde Pública e com o Código da Ética Profissional Odontológico, segundo a resolução CFO 179/93. 
Os pacientes foram informados da importância, objetivos, benefícios esperados, possíveis riscos e limitações deste estudo. Receberam, também, informações sobre o uso do laser e seus benefícios, embasadas na literatura. Após ouvir explicação e leitura cuidadosa da carta de informação ao paciente (ANEXO 1), e estando de acordo com as implicações do tratamento, os pacientes assinaram o termo de consentimento livre e esclarecido para a realização do tratamento. (ANEXO 2)

\subsection{Preparo prévio dos pacientes}

Os pacientes receberam instruções de higiene oral e se submeteram a procedimentos de raspagem e polimento coronário e, quando necessário, também foram removidos os fatores retentores de placa bacteriana, sendo colocados em um controle de placa rigoroso. Após 14 dias da obtenção do controle da inflamação, os pacientes foram reavaliados e, nos casos onde não houve regressão da hiperplasia e o contorno gengival permaneceu alterado, foi indicada a cirurgia de gengivoplastia (FIGURA 5).

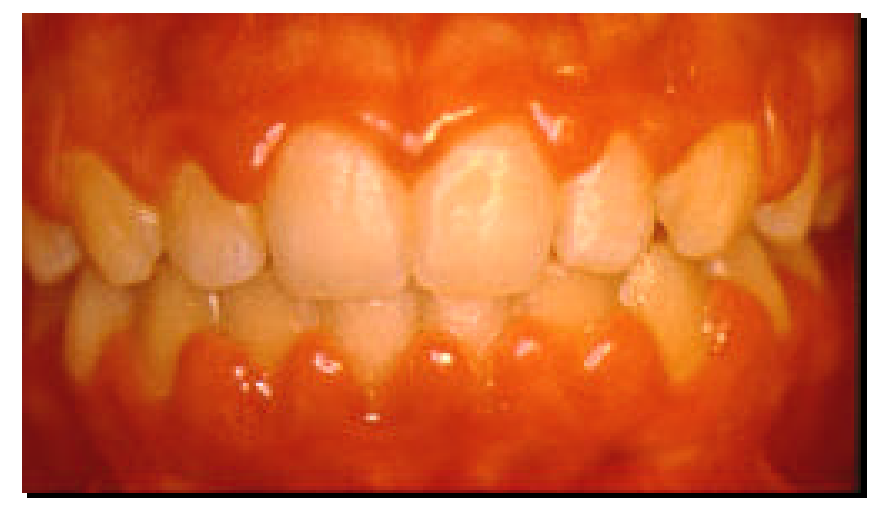

FIGURA-5 - Paciente com hiperplasia gengival inflamatória incluído no estudo 


\subsection{Fase cirúrgica}

Sob anestesia local com anestésico Mepivacaína 2\%*, foram realizadas cirurgias de gengivoplastia nas áreas de canino a canino superior e/ou inferior seguindo a técnica preconizada por GOLDMAN ${ }^{15}$ em 1958. Todas as cirurgias foram feitas pelo mesmo cirurgião dentista para que seguissem um mesmo padrão e duraram, em média, 45 min.

\subsection{Aplicação do laser}

Após obtenção da hemostasia na área, foi feita a aplicação do laser de GaAlAs (FIGURA 6) com as seguintes especificações:

- Laser KC 6120 VR - Kondortech

- Consumo: 30VA-60Hz

- Potência contínua - $15 \mathrm{~mW}$

- Densidade de energia - 0 a $15 \mathrm{~J} / \mathrm{cm}^{2}$

- Área de irradiação com ponta intrabucal $-4 \mathrm{~mm}^{2}$

- Comprimento de onda - 670nm - vermelho

- Emissor do laser - diodo GaAlAs

- Classificação de periculosidade - Classe IIB

\footnotetext{
*Scandicaíne $2 \%$ especial, Septodont.

Composição: cloridrato de mepivacaína 36mg,

adrenalina $18 \mu \mathrm{g}$
} 


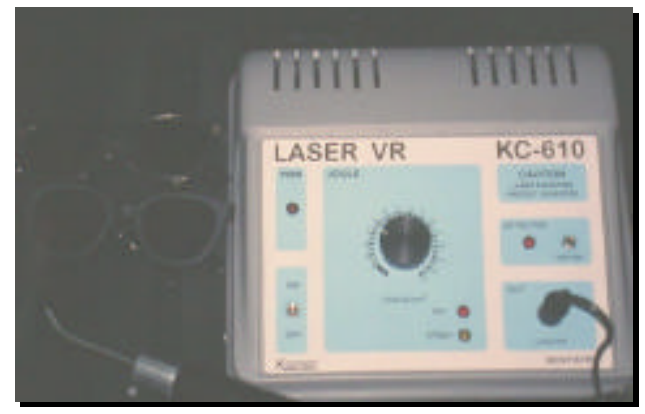

FIGURA 6 - Aparelho de laser GaAlAs - 670nm utilizado para este estudo, acompanhado dos óculos de proteção e ponta intrabucal.

A aplicação foi feita de forma pontual nas áreas gengivais correspondentes à cervical dos dentes $11,12,13$ ou 41,42,43. (FIGURAS 7a e 7b). O lado direito do paciente foi escolhido como lado teste. A densidade de energia aplicada foi $4 \mathrm{~J} / \mathrm{cm}^{2}$ em cada ponto, seguindo orientações do fabricante (efeito regenerativo ou reparativo 3 a $6 \mathrm{~J} / \mathrm{cm}^{2}$ ). A aplicação foi feita à distância de aproximadamente $1 \mathrm{~mm}$ do tecido gengival.

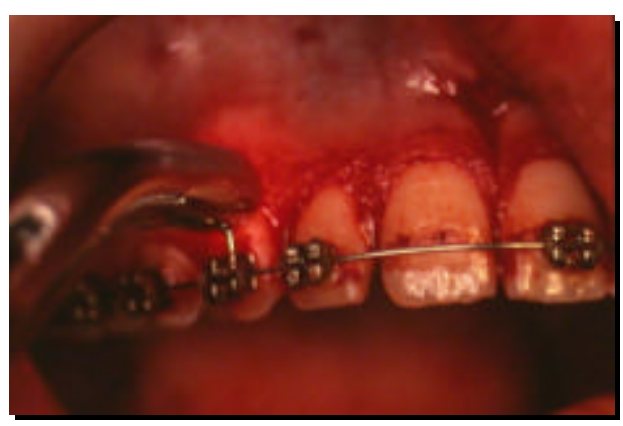

FIGURA 7a- Aplicação do

laser, logo após a cirurgia, no

lado teste.

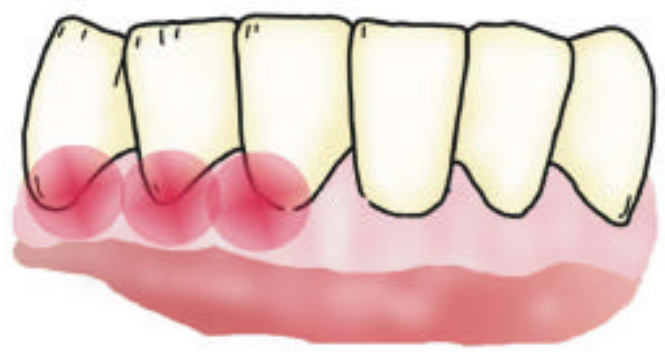

FIGURA 7b- Esquema da aplicação do laser da forma pontual em 3 pontos na região inferior. 
Como a utilização da ponta intra-oral promove uma redução de $20 \%$ na potência de emissão do laser, foi programado no aparelho o valor de 4,8 J/cm². O tempo de cada aplicação foi de 2 min e 30 s com um total de 6 min e 30 s. Foram tomadas as medidas de biossegurança como a utilização de óculos de proteção pelo operador e pelo paciente.

A ferida cirúrgica foi protegida com cimento cirúrgico Coe Pak* e foram dadas orientações de higiene e cuidados pós-operatórios. Foi receitado analgésico em caso de dor.

As aplicações de laser foram feitas conforme a descrição anterior, a cada $48 \mathrm{~h}$ durante uma semana, perfazendo um total de quatro sessões. A cada sessão, o cimento cirúrgico foi removido e a ferida cirúrgica foi limpa com bolinha de algodão embebida em soro fisiológico. Após a aplicação do laser, novo cimento cirúrgico foi colocado. Após sete dias, a área foi deixada desprotegida e repetiram-se as instruções de higiene ressaltando a necessidade de escovação delicada com escova extramacia na região operada.

Os controles pós-operatórios, após o período inicial, foram feitos com 7, 14, 21, 30 e 60 dias. Quando necessário, foi feita profilaxia com taça de borracha e pedra-pomes de granulação fina para controle da placa bacteriana e reorientação da higiene.

\subsection{Estudo clínico}

Os pacientes foram fotografados nos períodos de 7, 14, 21, 30, 60 dias com

\footnotetext{
* Coe Pack No Eugenol, Coe Laboratories Inc. - Chicago - Illinois
} 
uma máquina Nikon F60 e filme para eslaide de 35mm. As fotos aproximadas da área teste e controle foram padronizadas. Também foi tirada uma fotografia englobando toda a região anterior para que se pudesse ter uma visão panorâmica da área operada.

A análise clínica foi feita por 5 examinadores, sendo 3 alunos de mestrado e 2 alunos de doutorado, da área de Periodontia, com a mesma formação acadêmica. Os eslaides foram projetados em sala escura e não foi permitida a comunicação entre os examinadores. Foi feita uma projeção dupla das fotografias em "close" do lado teste e controle e, em seguida, a fotografia que englobava ambos os lados. Aos examinadores foram dadas informações de que o laser foi aplicado aleatoriamente em um dos lados, sem discriminação de qual lado foi irradiado. Foi marcado numa ficha qual dos lados se apresentava mais bem cicatrizado ou se ambos eram semelhantes (ANEXO 3). Cor, textura e contorno gengival foram tomados como padrão para comparação das áreas.

\subsection{Estudo Histológico}

\subsubsection{Coleta do material}

Sob anestesia local, 36 biópsias incisionais foram realizadas, com lâmina de bisturi 15C (FIGURA 8). Em 4 pacientes obteve-se uma peça do lado teste (direito) e outra do lado controle (esquerdo), perfazendo 8 peças, correspondentes ao pósoperatório de 7 dias. Aos 15 dias, outros 4 pacientes foram biopsiados. Nos períodos de 21 e 60 dias, 10 pacientes foram submetidos à biópsia, sendo 5 em cada período experimental. Foram no total, 13 pacientes operados e 18 áreas experimentais. A 
escolha entre os arcos superior e inferior foi aleatória.

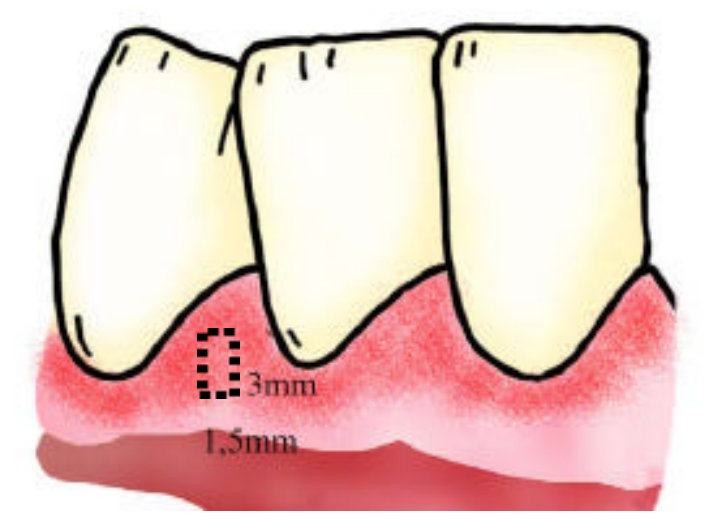

FIGURA 8 - Esquema ilustrando o local e as dimensões da biópsia realizada no lado teste. Da mesma maneira foi praticada a biópsia no lado controle.

\subsubsection{Processamento histológico}

Após a coleta, as peças foram fixadas em formol a 10\% em tampão fosfato* pH 7,3 durante uma semana. Em seguida, foram lavadas em água corrente durante 24h e mantidas em etanol a $70 \%$ até o dia seguinte.

O processamento histológico constou de desidratação em etanol, diafanização em xilol e inclusão em Histosec ${ }^{\#}$ (parafina + resina sintética) liquefeita em estufa a $60^{\circ} \mathrm{C}$. Cortes semi-seriados de $5 \mu \mathrm{m}$ de espessura foram obtidos em um micrótomo ${ }^{\bullet} \mathrm{e}$ corados pela técnica da Hematoxilina-Eosina.

\footnotetext{
*Solução tampão preparada para pH 7,3 da seguinte maneira:

Monofosfato de sódio hidratado $\left(\mathrm{NaH}_{2} \mathrm{PO}_{4} \cdot \mathrm{H}_{2} \mathrm{O}\right) \quad 4,02 \mathrm{~g}$

Difosfato de sódio hidratado $\left(\mathrm{NaHPO}_{4} \cdot 12 \mathrm{H}_{2} \mathrm{O}\right) \quad 16,37 \mathrm{~g}$

Água destilada q.s.p. $\quad 1000$

\# Laboratório Merck • Jung-Leica RM2045
} 


\subsubsection{Análise estereológica}

Estereologia é uma metodologia que estuda, através de fórmulas matemáticas, os aspectos tridimensionais de estruturas a partir de medidas bidimensionais obtidas de cortes dessas estruturas. Resumidamente, é o conceito pelo qual se pode interpretar cortes espacialmente ${ }^{59}$.

\subsubsection{Casualização dos campos histológicos}

Os métodos estereológicos são baseados em princípios geométricosestatísticos, derivados da probabilidade de as imagens dos perfis das estruturas na secção histológica coincidirem com um sistema-teste apropriado. Desse modo, um dos pontos críticos da estereologia está na casualização da amostra, ou seja, a escolha dos membros da amostra do tecido a serem confrontadas com o sistema-teste deve ser realizada por um método que elimine a ocorrência de vício.

Isso é conseguido pela aplicação de procedimentos de casualização na seleção das lâminas, dos cortes histológicos em cada lâmina e, principalmente, dos campos histológicos a serem utilizados nas quantificações.

No presente estudo, de cada biópsia foram obtidas 10 lâminas contendo 5 cortes semi-seriados cada uma. Por sorteio foram escolhidas 5 lâminas para serem utilizadas e de cada lâmina selecionado um (1) corte histológico.

A escolha dos 10 campos histológicos por corte, foi realizada em intervalos regulares de maneira que todas as regiões do corte histológico estivessem proporcionalmente representadas. 


\subsubsection{Análise do tecido epitelial em diferentes fases de maturação}

\section{a) Avaliação da espessura do epitélio}

A espessura do epitélio gengival e a densidade de volume (Vvi) de cada um dos seus estratos foram determinadas em um sistema de análise de imagem digitalizada, composto por um microscópio Zeiss Axioskop 2 com objetiva de imersão 40X, câmera CCD-IRIS RGB - Sony e software Kontron KS300* instalado em um computador IBM. (FIGURA 9)

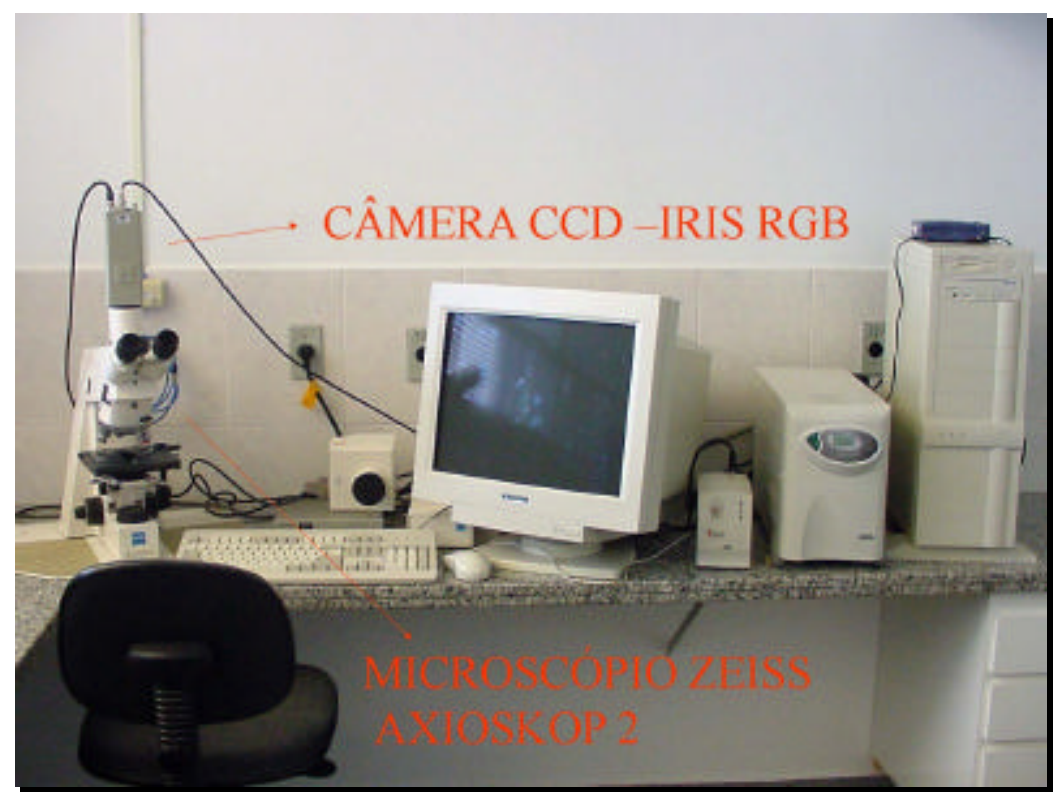

FIGURA 9 - Equipamento utilizado para análise do epitélio. A câmera acoplada ao microscópio permite que as imagens sejam transferidas ao computador e depois medidas com o auxílio de um software.

*(Kontron Electronic GMBM) 
Para tanto, foram capturadas 25 imagens casualisadas. Nessas imagens foram determinadas: a área ocupada por cada estrato epitelial (Ai), a área total do epitélio (A), comprimento total da superfície luminal ( $\mathrm{Sl})$ e basal ( $\mathrm{Sb})$.

A densidade de área de cada camada epitelial foi calculada pela relação:

$$
\mathrm{Avi}=\mathrm{Ai} / \mathrm{A}=\mathrm{Vvi}
$$

Tendo como base que a superfície luminal é plana, determinoutse a espessura média do epitélio através da fórmula: $\mathrm{h}=\mathrm{A} / \mathrm{Sl}$, onde $\mathrm{h}=$ espessura média do epitélio.

A relação superfície luminal $(\mathrm{Sl}) /$ basal $(\mathrm{Sb})$ do epitélio $(\mathrm{Rl} / \mathrm{b})$ foi calculada pela relação: $\mathrm{Rl} / \mathrm{b}=\mathrm{Sl} / \mathrm{Sb}$ (FIGURA 10)

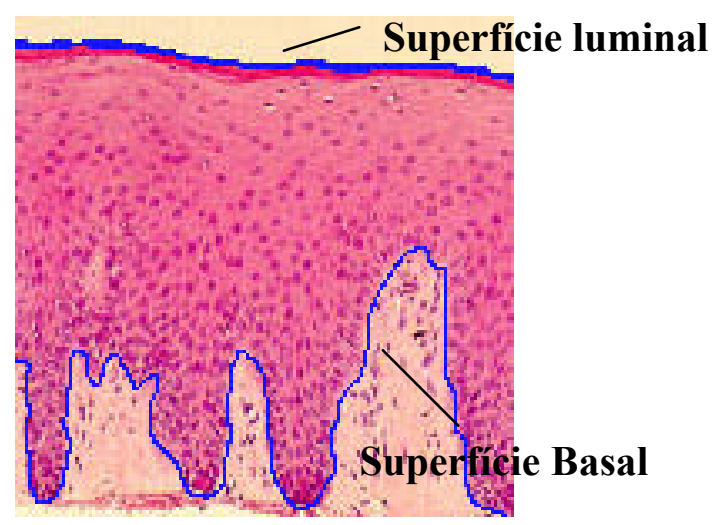

FIGURA 10 - Epitélio bucal com 60 dias de pós-operatório. (H.E. - 10x). Delimitação, em azul, da extensão da superfície luminal (Sl) e basal (Sb).

b) Avaliação do volume nuclear e celular das células dos estratos germinativo, espinhoso e córneo 
O volume nuclear (Vni) das células dos estratos germinativo, espinhoso e córneo foi calculado a partir de medidas ortogonais de 30 núcleos inteiros de cada tipo celular por peça, realizadas com uma ocular micrométrica Olympus, tipo Ramsden 10x, e uma objetiva de imersão 100x. O diâmetro geométrico médio (D) de cada núcleo medido foi calculado pela fórmula:

$$
\mathrm{D}=\sqrt{\mathrm{D}_{1} \cdot \mathrm{D}_{2}}
$$

O volume nuclear (Vni) foi calculado usando-se a fórmula geométrica do volume da esfera:

$$
\mathrm{Vni}=4 / 3 \pi \cdot \mathrm{r}^{3}
$$

A densidade de volume do núcleo $(\rho \mathrm{Ni})$, ou seja, a fração de volume celular ocupada pelo núcleo foi determinada pelo método de contagem de pontos, utilizando-se de uma ocular Kpl 8x Zeiss e objetiva de imersão 100x contendo o retículo de integração II Zeiss composto de 10 linhas paralelas e 100 pontos numa área quadrangular (FIGURA 11).

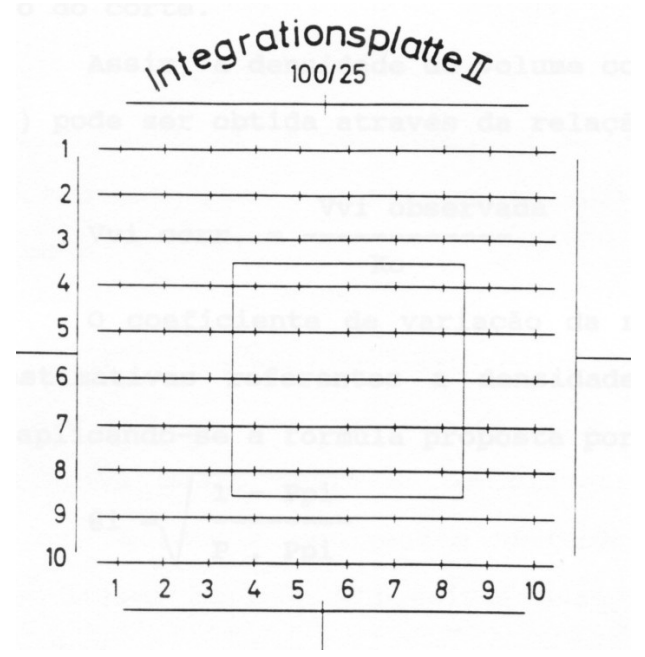

FIGURA 11 - Gratículo II Zeiss, utilizado para a análise morfométrica. 
Em 25 campos histológicos casualizados por biópsia contou-se o número total de pontos sobre os núcleos de células (Pni) de uma determinada camada (i ) e o número de pontos sobre o citoplasma (Pciti) dessas mesmas células. A densidade de volume do núcleo ( $\rho$ ni) foi calculada pela relação: $\rho$ ni = Pni / Pni+Pciti.

Em cortes de $5 \mu \mathrm{m}$, a grande maioria das imagens de núcleos representa transecções nucleares envoltas ou sobrepostas por citoplasma. Como os núcleos são corados mais densamente do que o citoplasma, na volumetria relativa de contagem de pontos esse citoplasma não é quantificado, causando uma sobreestimativa da densidade de volume do núcleo (efeito Holmes). Essa sobreestimativa da fração de volume celular ocupada pelo núcleo foi corrigida pelo fator de correção (Ko), calculado usando-se a relação: $\mathrm{Ko}=1+3 \mathrm{t} / 2 \mathrm{D}$, onde $\mathrm{t}=$ espessura do corte e $\mathrm{D}=$ diâmetro médio do núcleo ${ }^{60}$.

A densidade de volume corrigida do núcleo ( $\rho$ Nicorr) e do citoplasma ( $\rho$ cit) é: $(\rho \mathrm{Nicorr})=\rho \mathrm{Ni} / \mathrm{Ko}, \quad \rho c i t=1-\rho \mathrm{Ni}$ corr, respectivamente. Sabendo-se o valor do volume nuclear (Vni) e a fração do volume celular ocupada pelo núcleo ( $\rho$ Nicorr) e citoplasma ( $\rho$ citi), o volume citoplasmático foi determinado pela relação:

Vcit $=$ Vni $\times$ pciti/ $\rho$ Ni corr

Com a soma do volume nuclear e citoplasmático foi obtido o volume celular (Vcel).

\subsubsection{Análise do Tecido Conjuntivo Reparacional}

\section{a) Avaliação do número de células}

A avaliação do número de fibroblastos, células inflamatórias mononucleares e 
polimorfonucleares foi realizada pelo método II de $\mathrm{AHERNE}^{1}$ utilizando-se uma ocular Kpl 8x Zeiss e objetiva de imersão 100x contendo o retículo de integração II Zeiss. (FIGURA 11)

Em 25 campos histológicos casualizados por biópsia, foi contado o número de núcleos (n) de cada tipo celular, assim como o número de intersecções (c) que as bordas dos perfis das imagens dos núcleos faziam com as linhas paralelas do sistemateste.

Conhecendo-se a área total examinada (A), a distância entre as linhas do sistema-teste (d), a espessura do corte (t) e o volume processado de tecido conjuntivo (Vp), o número de cada tipo celular foi calculado pela fórmula:

$$
\mathrm{N}=\frac{\cdots}{(.2 \mathrm{t})}
$$

\subsection{Análise estatística dos dados clínicos e histológicos}

Para avaliação dos dados clínicos, foi utilizado o Teste dos sinais com marcação negativa (-) para o lado controle, positiva (+) para o lado teste e nula (0) para lados iguais. Foi feito o teste Kappa para análise da concordância entre examinadores.

$\mathrm{Na}$ análise histológica, os dados quantitativos para os grupos teste e controle foram confrontados entre si pelo Teste-t pareado. Para o caso da densidade de volume, os dados originais sofreram transformação arco-seno antes dos testes estatísticos.

Todas as análises estatísticas foram feitas a um nível de significância de 5\% 
$(\mathrm{p}<0,05)$. Os testes estatísticos foram realizados com auxílio do programa Statistica for Windows v.5.1 da Stat Soft Inc. (USA). 
5 RESULTADOS 


\section{RESULTADOS}

\subsection{Estudo clínico}

A análise clínica foi feita considerando as fotografias padronizadas e observações clínicas realizadas ao longo do processo cicatricial.

Com uma semana de pós-operatório, a ferida cirúrgica encontrava-se recoberta por uma membrana esbranquiçada de espessura variável, facilmente removida com algodão embebido em soro fisiológico. Abaixo dessa camada havia áreas avermelhadas, porém em todos os pacientes as feridas já estavam recobertas pelo epitélio. As diferenças entre os lados teste e controle eram marcantes, na maior parte dos pacientes, mostrando cicatrização mais acelerada no lado teste. (FIGURA 12).

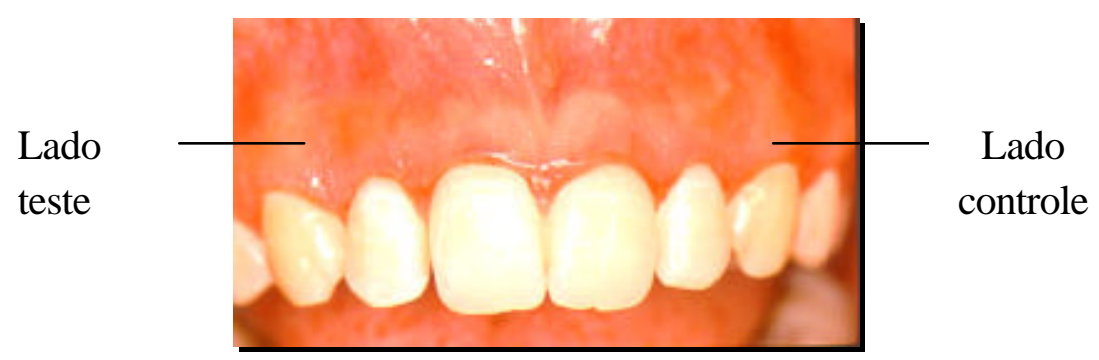

FIGURA 12 - Pós-operatório de 7 dias.

Com 15 dias pós-cirúrgicos, todas as feridas estavam completamente epitelizadas. Clinicamente, a mucosa ceratinizada se apresentava avermelhada, lisa e era nítida a diferença entre a área operada e as margens da ferida. Ainda era possível observar diferenças entre os lados, sendo o lado teste mais bem cicatrizado. (FIGURA 13). 


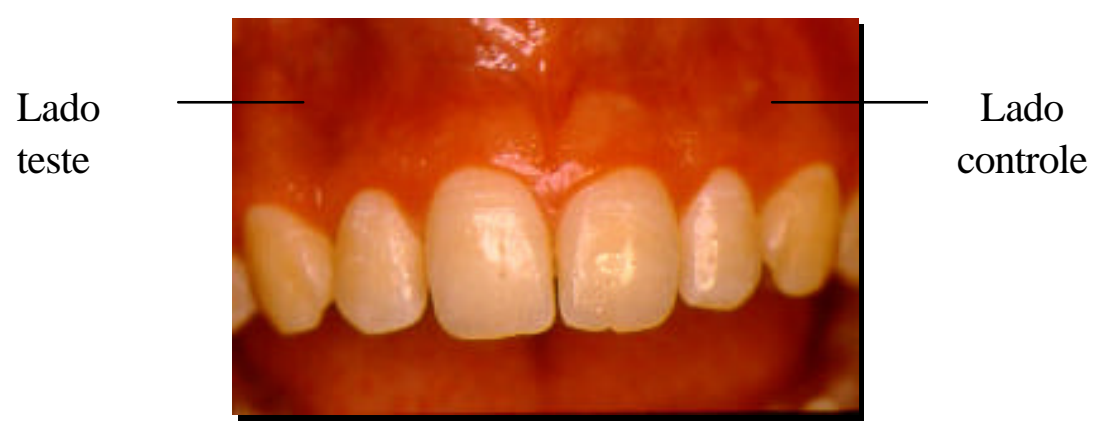

FIGURA 13 - Pós-operatório de 15 dias

Aos 21 dias pós-cirurgia, já não se observavam com nitidez, diferenças entre a área operada e a área não operada (FIGURA 14), já podendo notar-se uma certa migração da margem gengival em sentido coronal. Em alguns pacientes, as áreas de papilas ainda se apresentavam mais avermelhadas e era possível notar diferenças entre lado teste e controle, onde o lado teste estava mais bem cicatrizado.

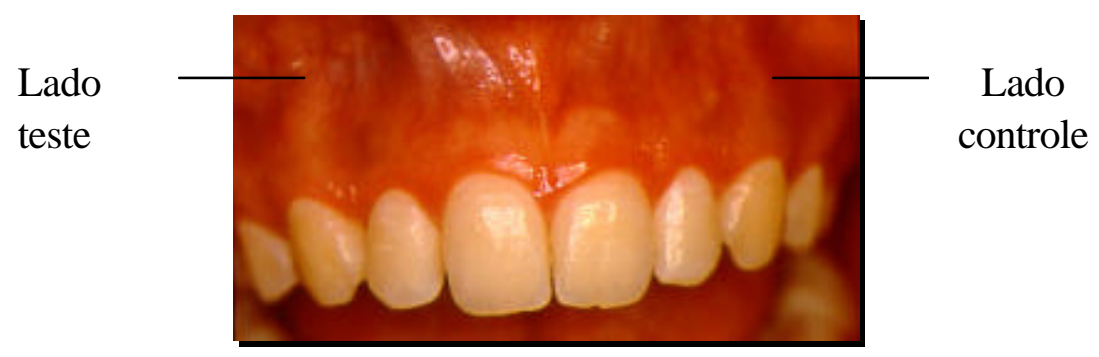

FIGURA 14 - Pós-operatório de 21 dias

Aos 30 dias de pós-operatório, já não se notavam diferenças entre os lados teste e controle. A mucosa ceratinizada apresentava-se com cor rosa pálido e, em alguns pacientes, o pontilhado semelhante à casca de laranja já era bem evidente (FIGURA 15). A migração da margem gengival em sentido coronal podia ser observada. 


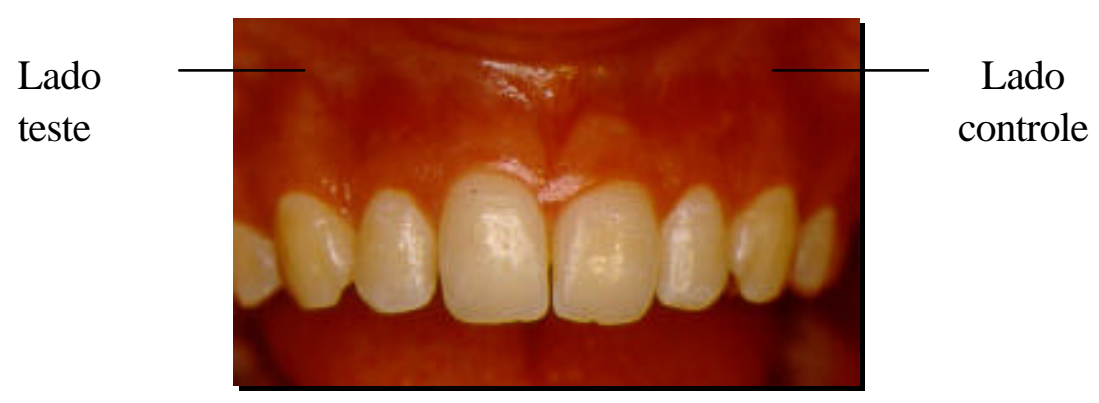

FIGURA 15 - Pós-operatório de 30 dias

Aos 60 dias de pós-operatório, a mucosa já se apresentava com todas as características de normalidade. $\mathrm{O}$ pontilhado semelhante à casca de laranja era bem evidente e notava-se estabilidade no nível da margem gengival (FIGURA 16). Em alguns pacientes, já era possível observar certa inflamação na margem gengival devido a um acúmulo de placa.

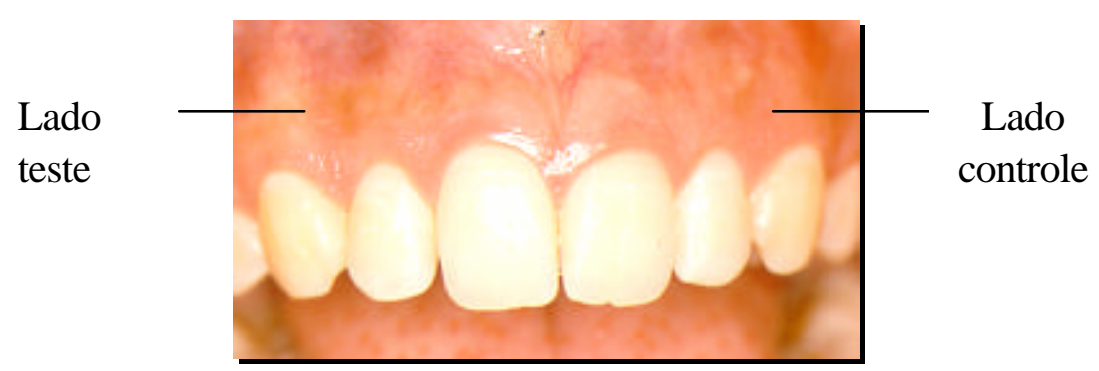

FIGURA 16 - Pós-operatório de 60 dias

A evolução do processo cicatricial, para os lados teste e controle, pode ser observada nas FIGURAS 17a a 21b, dispostas em uma mesma página para facilitar a comparação entre os lados. Esse caso clínico pertence ao mesmo paciente, onde se pode notar o lado teste (direito) com estágio mais avançado da cicatrização até o 
período de 21 dias. Nos períodos subseqüentes, ambos os lados estavam semelhantes.

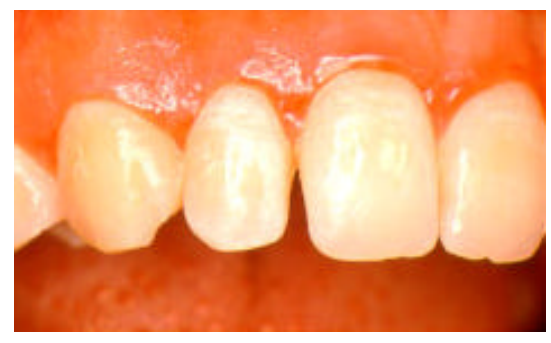

FIGURA 17 a -lado teste 7 dias

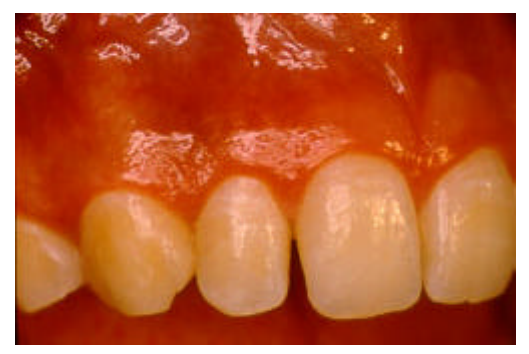

FIGURA $18 \mathrm{a}$ - lado teste 15 dias

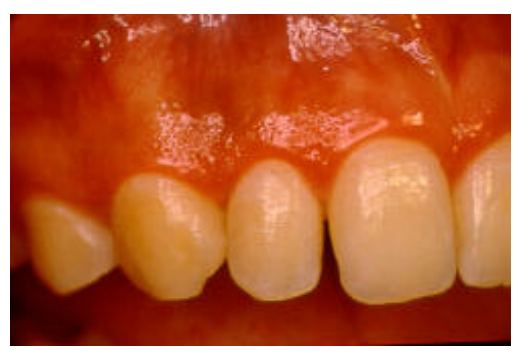

FIGURA 19a - lado teste 21 dias

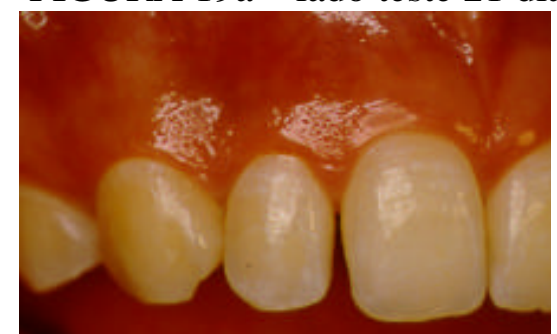

FIGURA 20a - lado teste 30 dias

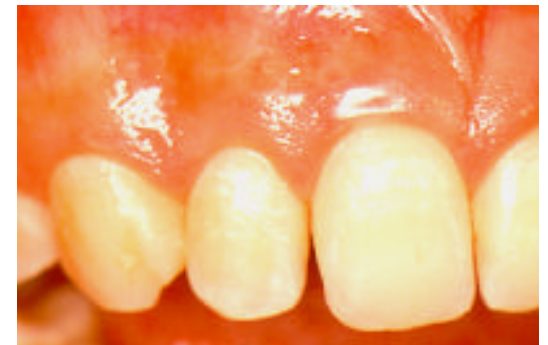

FIGURA 21a - lado teste 60 dias

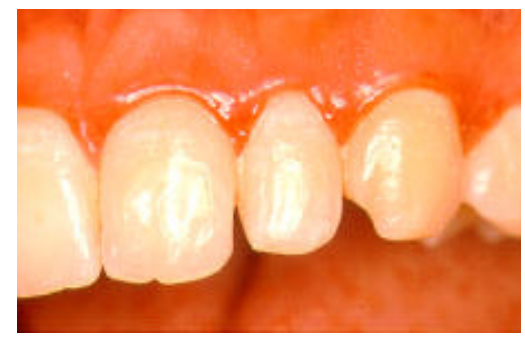

FIGURA $17 \mathrm{~b}$ - lado controle 7 dias

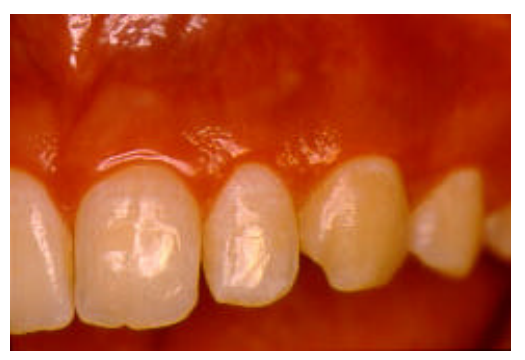

FIGURA 18b - lado controle 15 dias

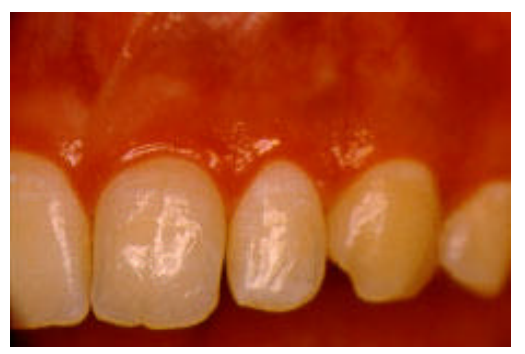

FIGURA 19b - lado controle 21 dias

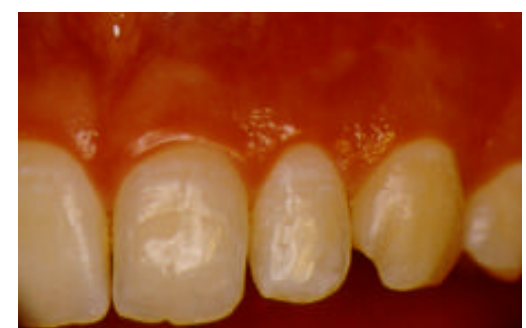

FIGURA 20b - lado controle 30 dias

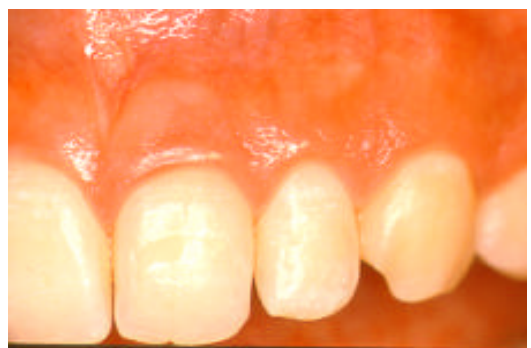

FIGURA 21b- lado controle 60 dias 
Com o intuito de se evitar a tendência de escolha do lado teste (direito) como mais bem cicatrizado pelo cirurgião dentista que realizou as cirurgias, optou-se por uma avaliação do padrão clínico de cicatrização por cinco examinadores através de fotografias. Para análise estatística dos resultados, foi utilizado o teste dos sinais que consiste em utilizar um sinal positivo (+) para o lado teste, negativo (-) para o controle e zero (0) quando não houve diferenças entre os lados. A maioria dos examinadores escolheu o lado esquerdo (controle) como mais bem cicatrizado aos 7 dias de pós-operatório. Com 15 dias, o lado direito (teste) foi considerado melhor. Aos 21 dias, o lado esquerdo (controle) foi novamente considerado com estágio mais avançado de cicatrização. E, aos 30 e 60 dias pós-cirúrgicos, houve uma grande semelhança em ambos os lados. Essa ava liação mostrou que nenhum desses valores foi estatisticamente significante para $\mathrm{p}<0,05$. (TABELA 1 ).

TABELA 1 - Teste dos sinais para avaliação clínica da evolução da cicatrização feita por cinco examinadores.

\begin{tabular}{ccccccc}
\hline & positivo + & negativo- & zero 0 & z & \multicolumn{2}{c}{ p } \\
\hline $\mathbf{7}$ dias $(\mathrm{n}=19)$ & 7 & 8 & 4 & 0 & 1 & $\mathrm{~ns}$ \\
$\mathbf{1 4}$ dias $(\mathrm{n}=17)$ & 8 & 4 & 5 & 0,86 & $0,38 \mathrm{~ns}$ \\
$\mathbf{2 1}$ dias $(\mathrm{n}=15)$ & 4 & 7 & 4 & 0,6 & $0,54 \mathrm{~ns}$ \\
$\mathbf{3 0}$ dias $(\mathrm{n}=19)$ & 1 & 5 & 13 & 1,22 & $0,22 \mathrm{~ns}$ \\
$\mathbf{6 0}$ dias $(\mathrm{n}=19)$ & 1 & 2 & 16 & 0 & 1 & $\mathrm{~ns}$ \\
\hline
\end{tabular}

ns - não estatisticamente significante para $\mathrm{p}<0,05$

(+) lado teste (-) lado contole (0) lados iguais

A FIGURA 22 também representa as análises dos observadores com a tendência de ora um, ora outro lado estar com processo cicatricial mais avançado até 21 dias e, posteriormente, se igualarem. 


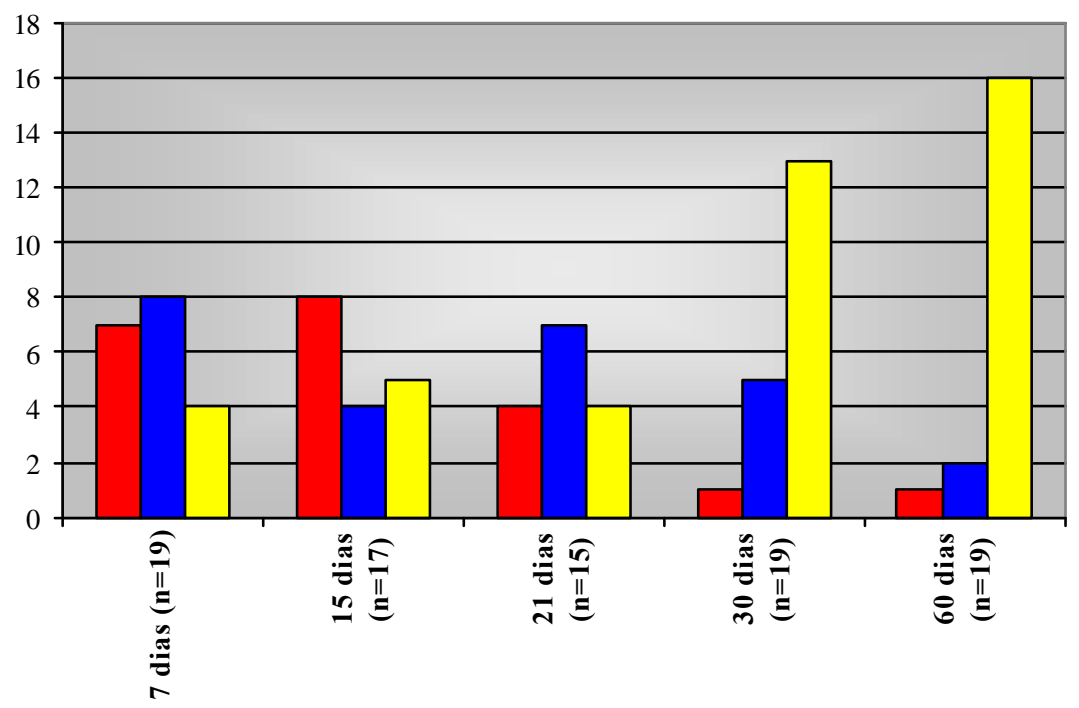

Lado teste $\square$ Lado controle $\square$ Lados iguais

FIGURA 22 - Análise eletiva dos observadores para o lado teste e controle ao longo do período experimental.

A concordância entre os examinadores foi baixa conforme mostrou o teste Kappa. Os valores de Kappa variaram de -0,16 a 0,73 nos vários períodos analisados. O valor médio do Kappa para o período de 7 dias foi 0,26; para 15 dias 0,36; para 21 dias 0,20 e para 60 dias, 0,17. (TABELA 2) Para interpretação desse teste, devem-se analisar valores próximos de 0 como concordância igual ao acaso e valores próximos de 1 , concordância total entre os examinadores. Como há certa dificuldade de se obter valor máximo nesse teste, costuma-se considerar ideais valores de Kappa entre 0,6 e 0,8, que significam concordância substancial dos examinadores.

TABELA 2 - Valores de Kappa para avaliação da concordância entre examinadores 
quanto à eleição da área mais bem cicatrizada ao longo do período experimental.

\begin{tabular}{|c|c|c|c|c|c|c|c|c|c|c|}
\hline & \multicolumn{5}{|c|}{7 dias } & \multicolumn{5}{|c|}{15 dias } \\
\hline examinadores & 1 & 2 & 3 & 4 & 5 & 1 & 2 & 3 & 4 & 5 \\
\hline 1 & $\mathrm{X}$ & 0,43 & 0,27 & 0,03 & 0,16 & $\mathrm{x}$ & 0,73 & 0,09 & 0,47 & 0,47 \\
\hline 2 & & $\mathrm{x}$ & 0,43 & 0,1 & 0,41 & & $\mathrm{x}$ & 0,04 & 0,48 & 0,48 \\
\hline 3 & & & $\mathrm{x}$ & 0,17 & 0,24 & & & $\mathrm{x}$ & 0,2 & 0,15 \\
\hline 4 & & & & $\mathrm{x}$ & 0,4 & & & & $\mathrm{x}$ & 0,57 \\
\hline 5 & & & & & $\mathrm{x}$ & & & & & $\mathrm{x}$ \\
\hline & \multicolumn{5}{|c|}{ Média $=0,26$} & \multicolumn{5}{|c|}{ Média $=0,36$} \\
\hline & \multicolumn{5}{|c|}{21 dias } & \multicolumn{5}{|c|}{30 dias } \\
\hline examinadores & 1 & 2 & 3 & 4 & 5 & 1 & 2 & 3 & 4 & 5 \\
\hline 1 & $\mathrm{x}$ & 0,36 & 0,20 & 0,13 & 0,41 & $\mathrm{x}$ & 0,46 & 0,3 & 0,47 & 0,37 \\
\hline 2 & & $\mathrm{x}$ & 0,06 & 0,24 & 0,23 & & $\mathrm{x}$ & 0,23 & 0,27 & 0,20 \\
\hline 3 & & & $\mathrm{x}$ & 0,19 & 0,09 & & & $\mathrm{x}$ & 0,17 & 0,11 \\
\hline 4 & & & & $\mathrm{x}$ & 0,12 & & & & $\mathrm{x}$ & 0,13 \\
\hline 5 & & & & & $\mathrm{x}$ & & & & & $\mathrm{X}$ \\
\hline & \multicolumn{5}{|c|}{ Média $=0,20$} & \multicolumn{5}{|c|}{ Média $=0,27$} \\
\hline \multicolumn{6}{|c|}{60 dias } & & & & & \\
\hline examinadores & 1 & 2 & 3 & 4 & 5 & & & & & \\
\hline 1 & $\mathrm{x}$ & 0,34 & 0,25 & 0,09 & $-0,16$ & & & & & \\
\hline 2 & & $\mathrm{x}$ & 0,17 & 0,35 & $-0,01$ & & & & & \\
\hline 3 & & & $\mathrm{x}$ & 0,11 & 0,34 & & & & & \\
\hline 4 & & & & $\mathrm{x}$ & 0,07 & & & & & \\
\hline 5 & & & & & $\mathrm{x}$ & & & & & \\
\hline & \multicolumn{5}{|c|}{ Média $=0,17$} & & & & & \\
\hline
\end{tabular}

\subsection{Estudo histológico}

\subsubsection{Análise morfológica}

A análise histológica em microscópio de luz permitiu a observação do processo cicatricial nos lados teste e controle compatíveis com as avaliações clínicas nos períodos em que as biópsias foram realizadas. A descrição foi feita de acordo 
com o tempo de cicatrização e as diferenças entre grupos, quando presentes, foram salientadas.

\section{7 dias (FIGURAS 23a e 23b)}

Epitélio ainda imaturo, com menor espessura, quando comparado ao de 60 dias (FIGURAS 28a e 28b), mostrando formação e crescimento das projeções epiteliais. Há presença do estrato granuloso pouco desenvolvido, mas contendo células com grânulos.O estrato germinativo exibe células com núcleos hipercorados no estrato basal e suprabasal. O estrato espinhoso exibe espaços intercelulares amplos na sua metade basal. Estrato córneo paraceratinizado, ainda em maturação, com eosinofilia não tão intensa, exibindo tendência de dissociação das camadas celulares após o processamento histológico. Tecido conjuntivo em organização.

\section{5 dias (Figuras 24a e 24b)}

Morfologia semelhante ao período anterior com algumas diferenças. $\mathrm{O}$ estrato germinativo ainda exibe núcleos hipercorados. O estrato espinhoso tem espaços amplos na sua metade basal. Nota-se o desaparecimento do estrato granuloso dando lugar a um estrato córneo com aumento gradual da eosinofilia no sentido das camadas celulares superficiais. Não há nitidez no limite entre estrato espinhoso e córneo, este último, paraceratinizado e relativamente espesso em relação aos períodos seguintes. As camadas celulares estão bem aderidas umas às outras sem a tendência de dissociação durante o processamento histológico. Tecido conjuntivo em organização. 


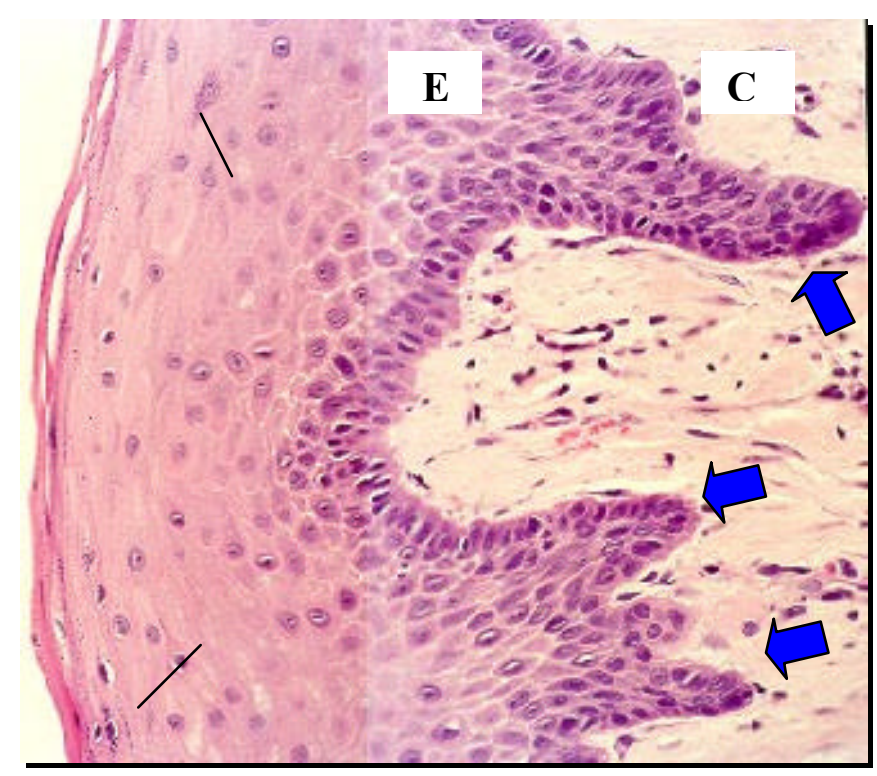

FIGURA 23a - Lado teste aos 7 dias de pós-operatório. Epitélio (E), projeções epiteliais (setas azuis), presença de grânulos na camada granulosa (setas pretas). Tecido conjuntivo (C). (H.E. $-40 x$ ).

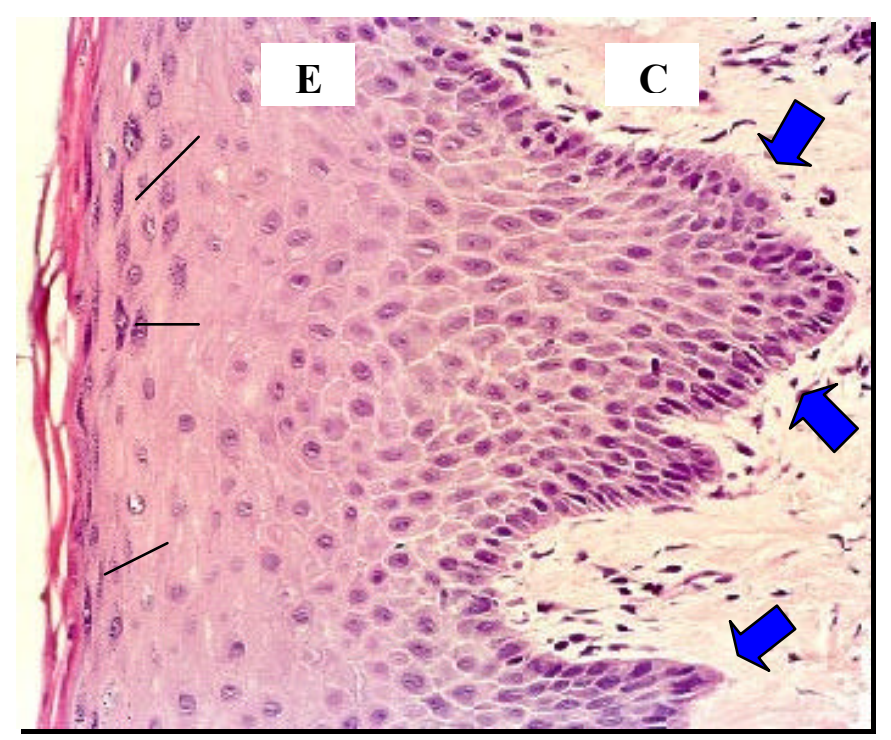

FIGURA 23b - Lado controle aos 7 dias de pós-operatório. Epitélio (E), projeções epiteliais (setas azuis), grânulos na camada granulosa (setas pretas). Tecido conjuntivo (C). (H.E.-40x). 


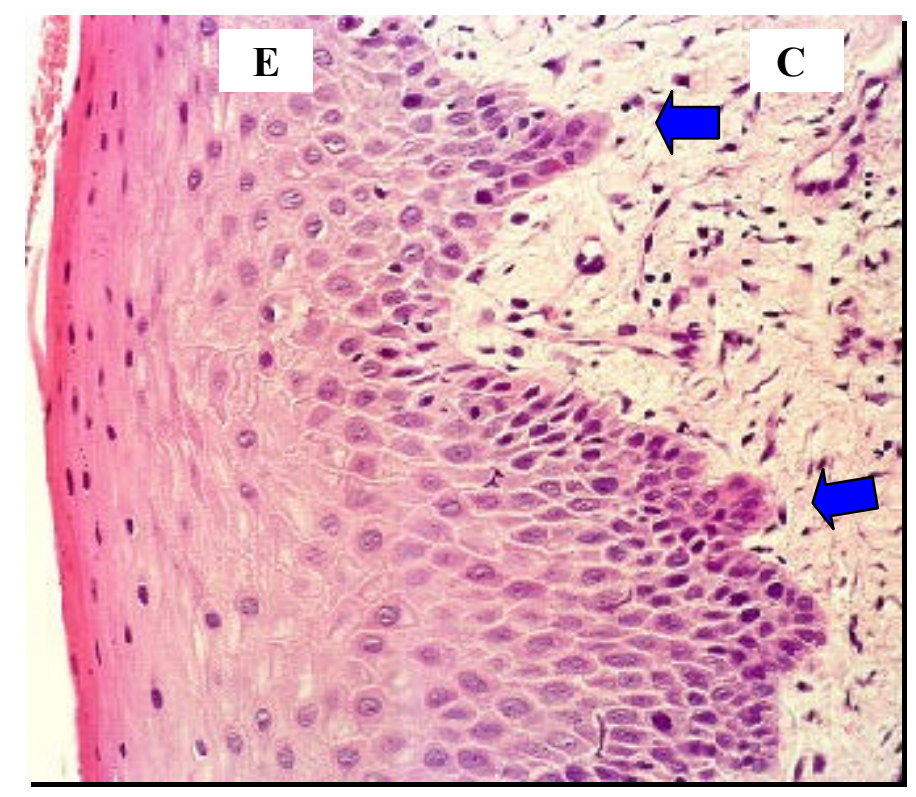

FIGURA 24a - Lado teste aos 15 dias pós-cirúrgicos. Formação de projeções epiteliais (setas azuis), epitélio (E), tecido conjuntivo (C). (H.E. -40x).

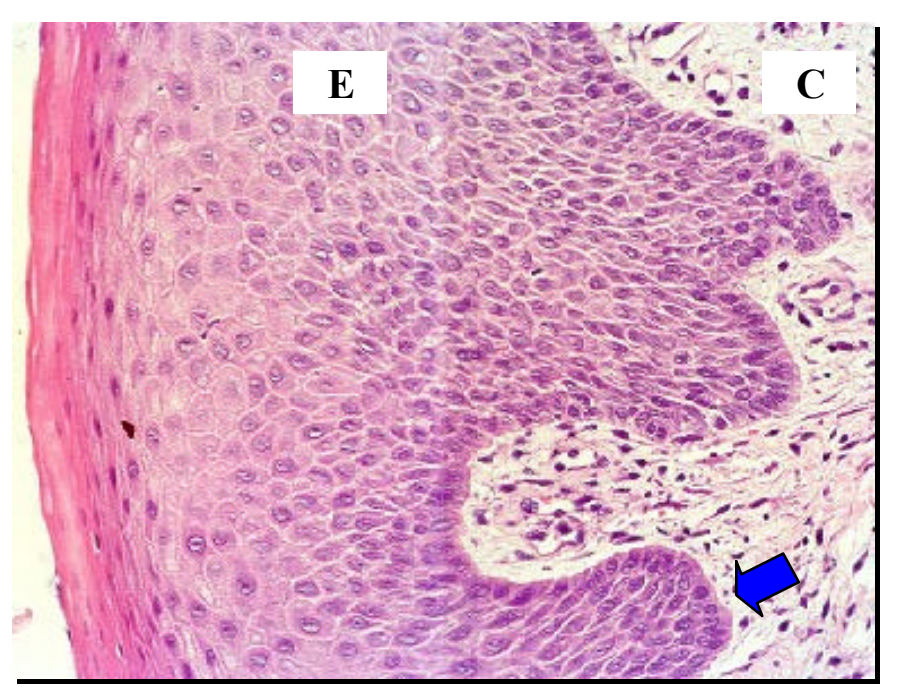

FIGURA 24b - Lado controle aos 15 dias pós-cirúrgicos. Projeções epiteliais em formação (seta azul), epitélio (E), conjuntivo (C). (H.E. -40x). 


\section{1 dias (FIGURAS 25a e 25b)}

O epitélio está próximo da maturidade com maior espessura, presença de cristas epiteliais e dos vários estratos bem definidos. O estrato germinativo ainda apresenta núcleos hipercorados na camada basal e suprabasal. O estrato espinhoso apresenta espaços intercelulares menores que nas etapas anteriores, no terço suprabasal, e os outros dois terços apresentam morfologia já bem próxima da observada aos 60 dias. Estrato granuloso ausente. Estrato córneo com morfologia paraceratinizada definitiva, peque na espessura, formada por poucas camadas celulares extremamente achatadas, eosinofilia intensa e sem tendência de dissociação das camadas durante o processamento histológico. O tecido conjuntivo já se apresenta mais organizado que nas fases anteriores, mostrando um número menor de células inflamatórias.

\section{0 dias (FIGURAS 26a e 26b)}

Epitélio já maduro, com projeções epiteliais longas e estratos bem definidos. O estrato germinativo já não exibe a hipercoloração nuclear. O estrato espinhoso se apresenta bastante desenvolvido, com espaços intercelulares difíceis de serem visualizados em toda espessura do estrato. Estrato granuloso ausente. Estrato córneo semelhante ao da etapa anterior, exibindo intensa eosinofilia. Tecido conjuntivo já maduro e bem organizado. 


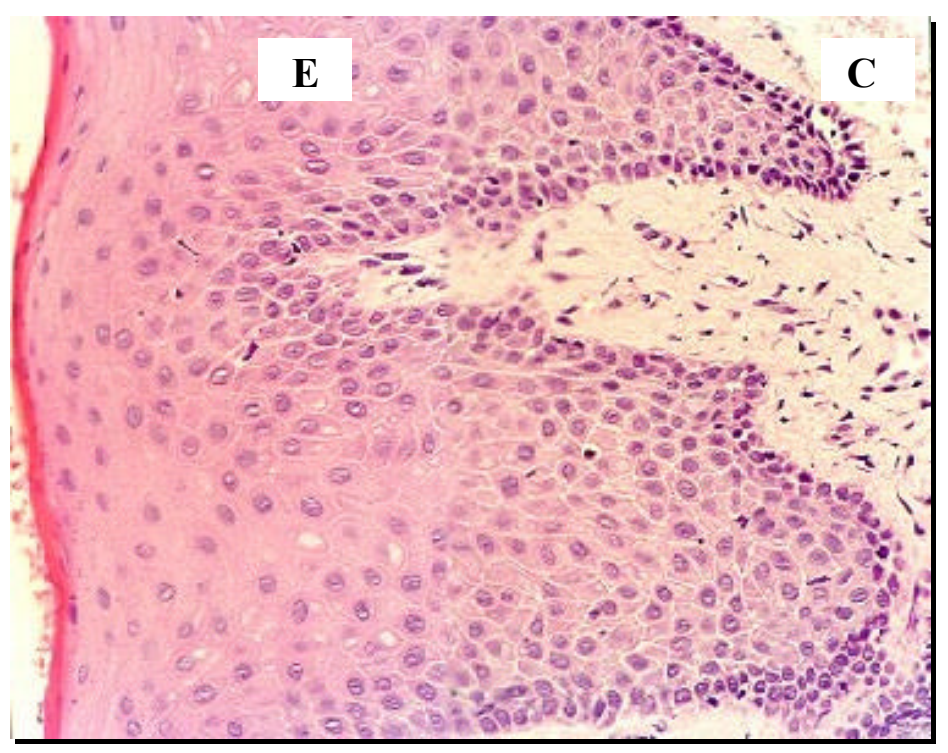

FIGURA 25a - Lado teste com 21 dias de pós-operatório. Epitélio (E), tecido conjuntivo (C). (H.E.-40x).

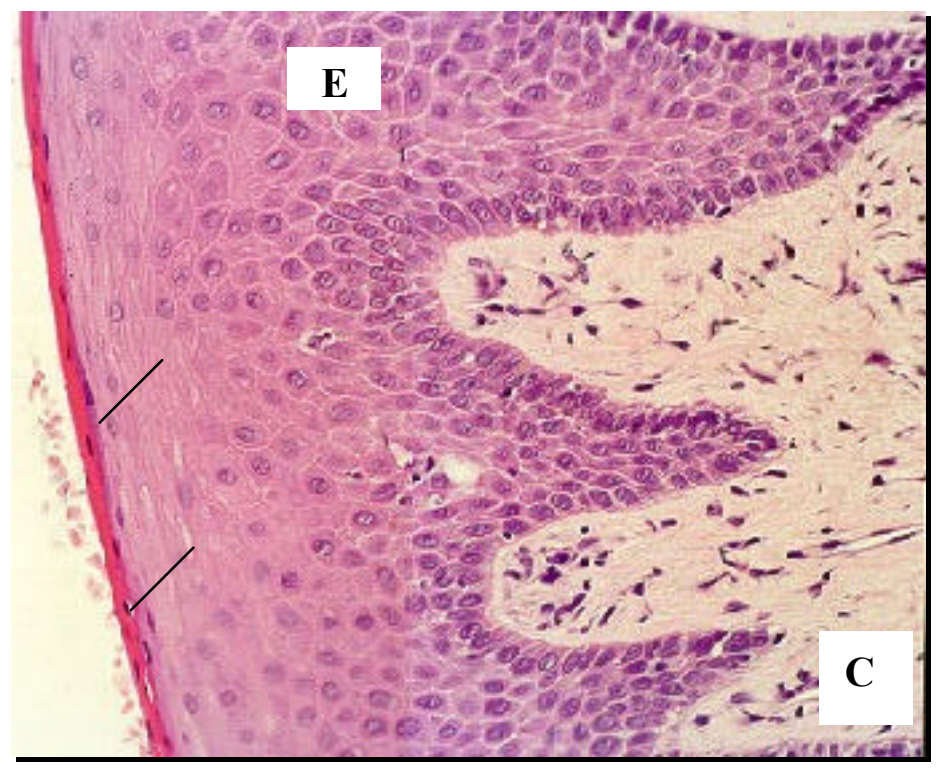

FIGURA 25b -Lado controle com 21 dias de pós-operatório. Epitélio (E), tecido conjuntivo (C). (H.E. - 40x). 


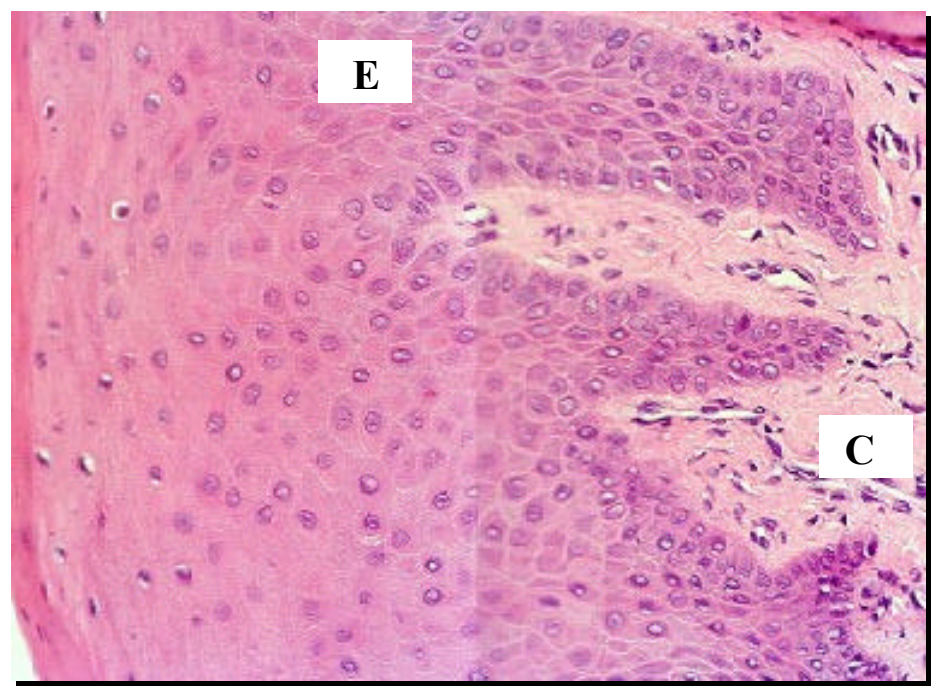

FIGURA 26a- Lado teste com 60 dias de pós-operatório. Epitélio (E), tecido conjuntivo (C). (H.E. 40x).

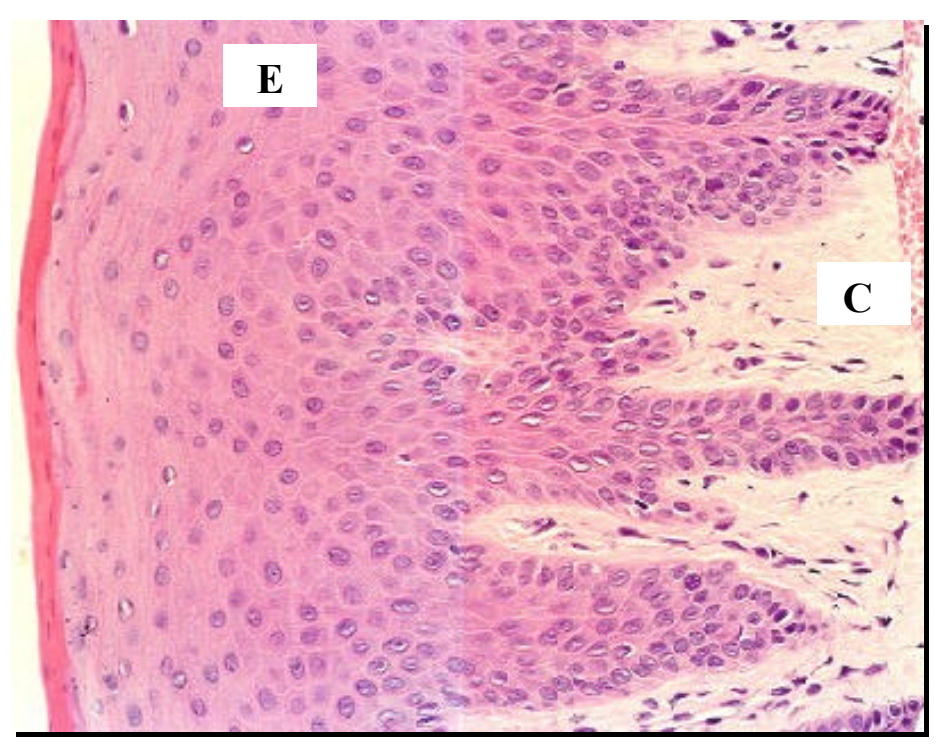

FIGURA 26b - Lado controle com 60 dias de pós-operatório. Epitélio (E), tecido conjuntivo (C). (H.E. 40x). 


\subsubsection{Análise estereológica}

A análise da densidade de volume dos estratos do epitélio mostrou que não houve diferenças estatisticamente significantes $(p>0,05)$ entre os grupos controle e teste, e dentro de cada grupo entre os períodos estudados. Isso mostra que as relações volumétricas entre estratos do epitélio já estavam estabelecidas aos 7 dias de pós-operatório. (TABELAS 3 e 4 - págs. 64 e 65).

O volume nuclear e citoplasmático, e conseqüentemente o volume da célula, no estrato basal não exibiram diferenças entre grupos nos vários períodos e entre períodos dentro de cada grupo. O volume nuclear e citoplasmático das células do estrato espinhoso e córneo diminuiu no transcorrer da maturação epitelial. No entanto, não houve diferenças significantes entre os grupos em nenhum dos períodos estudados. (TABELAS 3 e 4 - págs. 64 e 65). No estrato córneo, o volume do citoplasma e da célula, no período de 21 dias, ficou próximo do nível de significância (ANEXO 4). Nesse estrato, os valores de volume podem estar distorcidos porque muitas células da camada córnea perdem seus núcleos com a evolução de sua maturação.

A espessura do epitélio teve um aumento diretamente proporcional ao tempo tanto para o grupo teste quanto para o grupo controle, o qual pode ser observado na FIGURA 27. Esse aumento se deve à maturação do mesmo. Não houve diferenças estatisticamente significantes entre os grupos. (p>0,05) (TABELAS 3 e 4, págs. 64 e 65). 


\section{Espessura do epitélio}

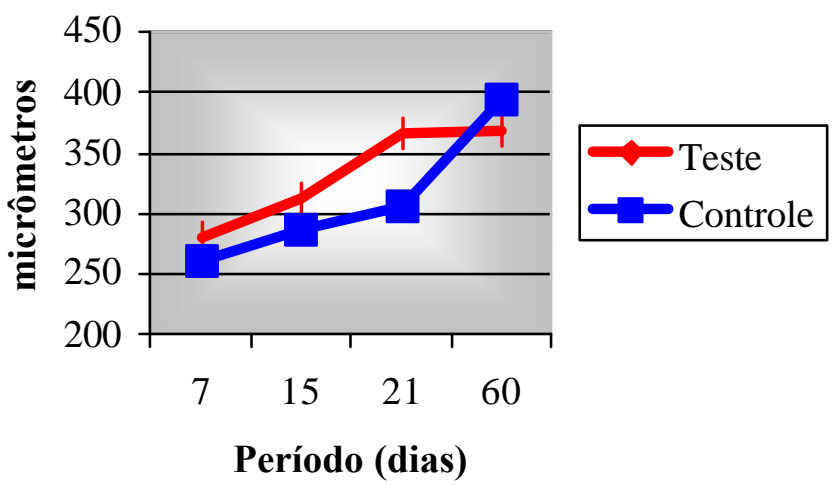

FIGURA 27 - Espessura epitelial ao longo do período estudado.

Quanto à relação entre a superfície luminal e basal, esta foi inversamente proporcional ao tempo, ou seja, houve um aumento significante da superfície basal durante o processo de maturação do epitélio pelo aumento no tamanho das cristas epiteliais até os 60 dias. Esse aumento é traduzido por um decréscimo dos valores da relação luminal e basal, os quais são frações (FIGURA 28). Não ocorreu diferença estatisticamente significante entre os grupos, embora no período de 21 dias esta relação tenha ficado bem próxima do nível de significância $(p=0,08)($ ANEXO 4), e com valor maior no lado controle.(TABELAS 3 e 4, págs. 64 e 65).

\section{Relação luminal e basal}

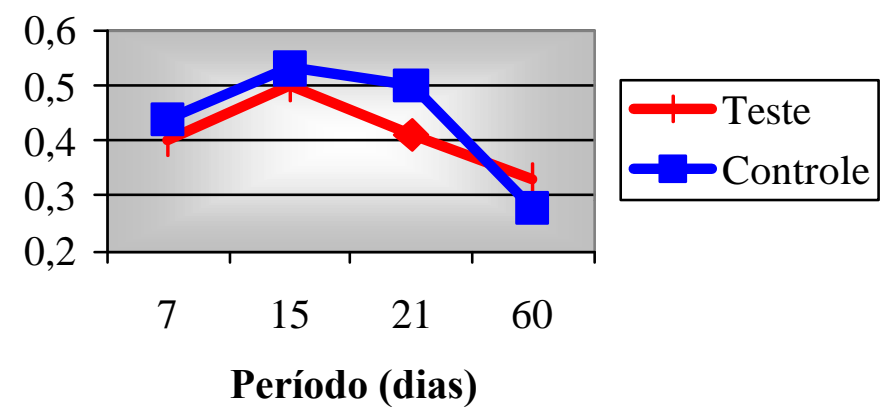


FIGURA 28 - Diminuição no valor da relação luminal e basal de acordo com o tempo.

No tecido conjuntivo da lâmina própria, o número de fibroblastos por unidade de tecido aumentou com o tempo refletindo a organização do tecido, a produção de fibras colágenas e a remodelação tecidual até atingir padrão característico de normalidade aos 60 dias. (FIGURA 29)( TABELAS 3 e 4, págs. 64 e 65).

\section{Número de fibroblastos}

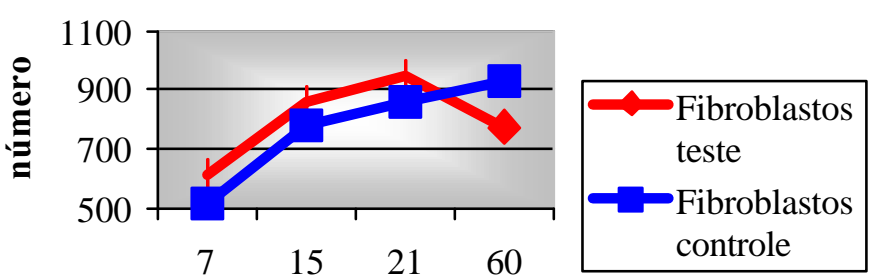

Período (dias)

FIGURA 29 - Aumento no número de fibroblastos em relação ao período estudado.

O número de células inflamatórias mononucleadas teve um pico no período de 15 dias diminuindo a seguir, mostrando que a reparação da ferida ocorreu de forma normal tanto no grupo teste como no grupo controle (FIGURA 30). Não houve diferenças entre os grupos, porém aos 7 dias havia mais células mononucleadas no lado teste e esta diferença ficou próxima do nível de significância $(\mathrm{P}=0,06)(\mathrm{ANEXO}$ 4). O número de polimorfonucleares (PMN) foi pequeno, tendo seu maior valor aos 7 dias e diminuindo nos períodos subseqüentes, o que reflete a fase aguda inicial da reparação da ferida (FIGURA 30). Nesta avaliação também não foi detectada diferença significante entre os grupos.(p>0,05) (TABELAS 3 e 4). 
Número de células inflamatóris
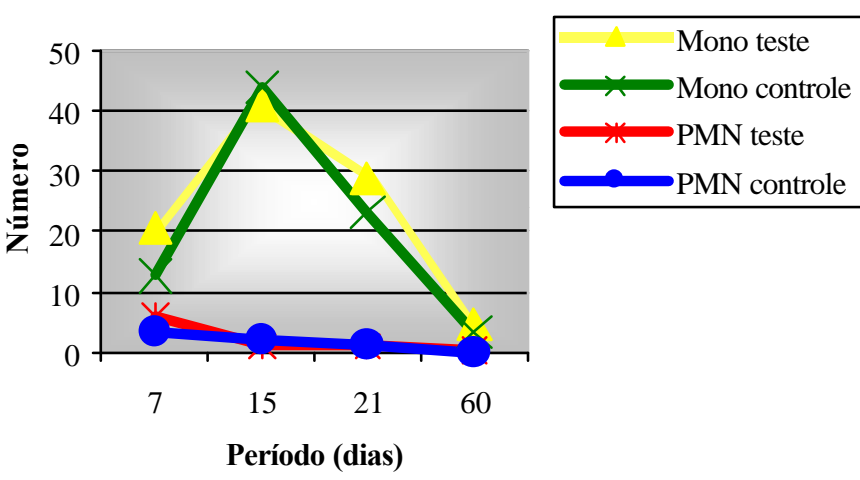

FIGURA 30 - Decréscimo no número de células inflamatórias mononucleares

(mono) e polimorfonucleares (PMN) em relação ao período estudado.

TABELA 3 - Resultados da análise estereológica para os períodos de 7 e 15 dias de pós-operatório.

\begin{tabular}{|c|c|c|c|c|c|}
\hline & & \multicolumn{2}{|c|}{7 dias } & \multicolumn{2}{|c|}{15 dias } \\
\hline & & $\begin{array}{c}\text { Teste } \\
\text { Média } \pm \text { EPM } \\
\end{array}$ & $\begin{array}{c}\text { Controle } \\
\text { Média } \pm \text { EPM } \\
\end{array}$ & $\begin{array}{c}\text { Teste } \\
\text { Média } \pm \text { EPM } \\
\end{array}$ & $\begin{array}{c}\text { Controle } \\
\text { Média } \pm \text { EPM } \\
\end{array}$ \\
\hline \multicolumn{6}{|c|}{ Densidade de Volume do Epitélio (\%) } \\
\hline & to Córneo & $\mathbf{2 4 , 0 8} \pm 1,47$ & $\mathbf{2 1 , 6 7} \pm 2,54$ & $\mathbf{2 6 , 6} \pm 4,7$ & $\mathbf{2 4 , 8 6} \pm 3,26$ \\
\hline & to Espinhoso & $\mathbf{5 3 , 4 4} \pm 1,46$ & $\mathbf{5 3 , 9 2} \pm 1,28$ & $\mathbf{5 4 , 3 2} \pm 4,78$ & $\mathbf{5 8 , 3 4} \pm 2,23$ \\
\hline & ato Basal & $\mathbf{2 2 , 4 7} \pm 1,15$ & $\mathbf{2 4 , 4} \pm 1,99$ & $\mathbf{1 9 , 0 7} \pm 4,21$ & $\mathbf{1 6 , 7 9} \pm 1,47$ \\
\hline \multicolumn{6}{|c|}{ Relação Luminal e Basal } \\
\hline & & $\mathbf{0 , 4} \pm 0,07$ & $\mathbf{0 , 4 4} \pm 0,09$ & $\mathbf{0 , 5 0} \pm 0,10$ & $\mathbf{0 , 5 3} \pm 0,08$ \\
\hline \multicolumn{6}{|c|}{ Espessura do Epitélio ( $\mu$ m) } \\
\hline & & $\mathbf{2 7 9 , 6 7} \pm 35,04$ & $\mathbf{2 6 0 , 5 8} \pm 11,55$ & $\mathbf{3 1 1 , 9 1} \pm 51,18$ & $\mathbf{2 8 7 , 0 2} \pm 16,75$ \\
\hline \multicolumn{6}{|c|}{ Volume Nuclear e Celular $\left(\mu \mathrm{m}^{3}\right)$} \\
\hline & Núcleo & $\mathbf{1 9 3 , 2 7} \pm 20,57$ & $\mathbf{2 1 1 , 8 9} \pm 23,59$ & $\mathbf{1 9 7 , 6 3} \pm 7,37$ & $\mathbf{2 0 7 , 8 7} \pm 22,22$ \\
\hline \multirow[t]{3}{*}{ Basal } & Citoplasma & $\mathbf{4 1 5}, \mathbf{4 5} \pm 35,22$ & $\mathbf{4 6 8 , 9 7} \pm 79,78$ & $\mathbf{4 6 2 , 8 6} \pm 12,41$ & $487,04 \pm 55,62$ \\
\hline & Célula & $\mathbf{6 0 8 , 7} \pm 35,88$ & $\mathbf{6 8 0 , 8 6} \pm 93,63$ & $\mathbf{6 6 0 , 5} \pm 19,38$ & $\mathbf{6 9 4 , 9 1} \pm 76,65$ \\
\hline & Núcleo & $\mathbf{3 1 8 , 2 5} \pm 13,15$ & $\mathbf{3 1 6 , 4 2} \pm 18,58$ & $\mathbf{2 9 6 , 1 4} \pm 22,22$ & $\mathbf{2 9 5 , 1 7} \pm 21,04$ \\
\hline \multirow[t]{3}{*}{ Espinhoso } & Citoplasma & $2902 \pm 252,01$ & $\mathbf{3 3 4 6 , 8 4} \pm 439,48$ & $\mathbf{1 9 0 8 , 1 7} \pm 191,11$ & $\mathbf{2 0 3 7 , 9} \pm 335,27$ \\
\hline & Célula & $\mathbf{3 2 2 0 , 2 6} \pm 258,25$ & $\mathbf{3 6 6 3 , 2} \pm 447,70$ & $\mathbf{2 2 0 4 , 3 1} \pm 207,82$ & $\mathbf{2 3 3 3 , 0 7} \pm 343,72$ \\
\hline & Núcleo & $\mathbf{4 7 , 8 4} \pm 6,28$ & $\mathbf{3 7 , 4 1} \pm 6,58$ & $\mathbf{4 1 , 4} \pm 8,13$ & $\mathbf{3 3}, \mathbf{4 6} \pm 6,14$ \\
\hline \multirow[t]{2}{*}{ Córneo } & Citoplasma & $\mathbf{1 4 8 7 , 2 5} \pm 216,41$ & $\mathbf{1 3 3 2 , 5 3} \pm 230,20$ & $\mathbf{1 1 1 0}, 7 \pm 223,91$ & $\mathbf{9 2 2 , 2 8} \pm 178,33$ \\
\hline & Célula & $\mathbf{1 5 3 5 , 2 5} \pm 221,31$ & $\mathbf{1 3 6 9 , 9 4} \pm 235,58$ & $\mathbf{1 1 5 2 , 1 1} \pm 231,91$ & $\mathbf{9 5 5 , 7 2} \pm 184,22$ \\
\hline \multicolumn{6}{|c|}{ Número de células $/ \mathrm{mm}^{3}$ do conjuntivo } \\
\hline Fibr & lastos & $\mathbf{6 1 3 , 8 9} \pm 42,99$ & $\mathbf{5 1 9 , 9 9} \pm 44,23$ & $\mathbf{8 5 8 , 8 9} \pm 80,34$ & $\mathbf{7 8 2 , 7 7 \pm 1 1 9 , 2 8}$ \\
\hline Mon & nucleares & $\mathbf{2 0 , 5 5} \pm 1,06$ & $\mathbf{1 2 , 7 7} \pm 1,90$ & $\mathbf{4 1 , 1 1 \pm 1 3 , 3 5}$ & $\mathbf{4 3 , 8 9} \pm 16,51$ \\
\hline Polir & rfonucleares & $\mathbf{6 , 1 0} \pm 2,46$ & $\mathbf{3 , 3 3} \pm 1,43$ & $\mathbf{1 , 1 1} \pm 0,64$ & $\mathbf{2 , 2 2} \pm 1,57$ \\
\hline
\end{tabular}

EPM= erro padrão da média Nenhuma comparação foi significante para $p<0,05$ 
TABELA 4 - Resultados da análise estereológica para os períodos de 21 e 60 dias de pós-operatório.

\begin{tabular}{|c|c|c|c|c|c|}
\hline & & \multicolumn{2}{|c|}{21 dias } & \multicolumn{2}{|c|}{60 dias } \\
\hline & & Teste & Controle & Teste & Controle \\
\hline & & Média \pm EPM & Média \pm EPM & Média \pm EPM & Média \pm EPM \\
\hline \multicolumn{6}{|c|}{ Densidade de Volume do Epitélio (\%) } \\
\hline Estr & Córneo & $\mathbf{2 3 , 6 2} \pm 3,74$ & $\mathbf{2 4 , 6 5} \pm 3,30$ & $\mathbf{2 2 , 5 1} \pm 1,79$ & $\mathbf{2 1 , 1 2} \pm 1,74$ \\
\hline Est & o Espinhoso & $\mathbf{5 8 , 0 1} \pm 3,85$ & $\mathbf{5 6 , 8 8} \pm 2,81$ & $\mathbf{5 6 , 6} \pm 3,05$ & $\mathbf{5 6 , 7 8} \pm 1,20$ \\
\hline Est & o Basal & $\mathbf{1 8 , 3 6} \pm 1,21$ & $\mathbf{1 8 , 4 6} \pm 1,87$ & $\mathbf{2 0 , 8 8} \pm 3,69$ & $\mathbf{2 2 , 0 5} \pm 1,30$ \\
\hline \multicolumn{6}{|c|}{ Relação Luminal e Basal } \\
\hline & & $\mathbf{0 , 4 1} \pm 0,07$ & $\mathbf{0 , 5} \pm 0,09$ & $\mathbf{0 , 3 3} \pm 0,05$ & $\mathbf{0 , 2 8} \pm 0,04$ \\
\hline \multicolumn{6}{|c|}{ Espessura do Epitélio ( $\mu \mathrm{m})$} \\
\hline & & $\mathbf{3 6 6 , 0 4} \pm 36,16$ & $\mathbf{3 0 6 , 6 4} \pm 31,13$ & $\mathbf{3 6 7 , 7 1} \pm 37,26$ & $\mathbf{3 9 3 , 5 4} \pm 13,34$ \\
\hline \multicolumn{6}{|c|}{ Volume Nuclear e Celular $\left.\left(\mu^{3}\right)^{3}\right)$} \\
\hline \multirow{4}{*}{ Basal } & Núcleo & $\mathbf{2 0 2 , 6 6} \pm 19,34$ & $\mathbf{2 1 9 , 8 3} \pm 25,68$ & $\mathbf{2 1 2 , 9} \pm 14,64$ & $\mathbf{2 1 8}, \mathbf{1 8} \pm 20,49$ \\
\hline & Citoplasma & $\mathbf{4 3 5 , 9 2} \pm 22,96$ & $\mathbf{4 4 1 , 7} \pm 51,32$ & $414,76 \pm 37,41$ & $\mathbf{4 1 6 , 3 1} \pm 34,66$ \\
\hline & Célula & $\mathbf{6 3 8 , 5 8} \pm 36,94$ & $\mathbf{6 6 1 , 5 4} \pm 75,82$ & $\mathbf{6 2 7 , 6 7 \pm 4 6 , 2 5}$ & $\mathbf{6 3 4 , 4 9} \pm 55,04$ \\
\hline & Núcleo & $\mathbf{2 4 0 , 5 2} \pm 15,11$ & $\mathbf{2 7 4 , 1 2} \pm 33,06$ & $\mathbf{2 6 6 , 8 2} \pm 17,17$ & $\mathbf{2 7 9 , 8 5} \pm 11,57$ \\
\hline \multirow[t]{3}{*}{ Espinhoso } & Citoplasma & $\mathbf{1 9 5 9 , 4 7} \pm 166,31$ & $\mathbf{2 2 4 0 , 3 3} \pm 443,39$ & $\mathbf{1 6 9 7 , 2 1} \pm 163,89$ & $\mathbf{2 0 0 5 , 4 2} \pm 166,70$ \\
\hline & Célula & $\mathbf{2 2 0 0} \pm 161,88$ & $\mathbf{2 5 1 4 , 4 6} \pm 472,68$ & $\mathbf{1 8 6 4 , 0 3} \pm 229,49$ & $\mathbf{2 2 8 5 , 2 8} \pm 170,76$ \\
\hline & Núcleo & $\mathbf{3 0 , 9 6} \pm 4,22$ & $\mathbf{3 3}, \mathbf{7 1} \pm 4,57$ & $\mathbf{3 0 , 4 7} \pm 4,77$ & $\mathbf{3 0 , 6 6} \pm 4,12$ \\
\hline \multirow[t]{2}{*}{ Córneo } & Citoplasma & $\mathbf{7 3 3 , 1} \pm 127,59$ & $\mathbf{1 0 1 3 , 5 6} \pm 144,56$ & $\mathbf{7 1 6 , 6 1} \pm 113,39$ & $\mathbf{8 0 4 , 6 1} \pm 75,21$ \\
\hline & Célula & $\mathbf{7 6 4 , 0 7} \pm 131,69$ & $\mathbf{1 0 4 7 , 2 8} \pm 148,79$ & $\mathbf{7 4 7 , 0 9} \pm 118,09$ & $\mathbf{8 3 5 , 3 3} \pm 78,54$ \\
\hline \multicolumn{6}{|c|}{ Número de células $/ \mathrm{mm}^{3}$ do conjuntivo } \\
\hline Fib & blastos & $\mathbf{9 4 6 , 1 1} \pm 94,49$ & $\mathbf{8 5 7 , 7 7 \pm 7 5}$ & $\mathbf{7 7 7 , 3 3} \pm 23,08$ & $\mathbf{9 3 2 , 4 4 \pm 7 6 , 8 9}$ \\
\hline Mo & nucleares & $\mathbf{2 8 , 8 8} \pm 6,35$ & $\mathbf{2 3}, \mathbf{3 3} \pm 5,77$ & $\mathbf{4 , 8 9} \pm 3,65$ & $\mathbf{3 , 5 5} \pm 2,49$ \\
\hline Poli & orfonucleares & $\mathbf{1 , 1 1} \pm 1,11$ & $\mathbf{1 , 1 1} \pm 0,64$ & $\mathbf{0 , 4 4} \pm 0,44$ & $\mathbf{0}$ \\
\hline
\end{tabular}

EPM= erro padrão da média Nenhuma comparação foi significante para $p<0,05$ 


\section{DISCUSSÃO}

O presente estudo contou com a colaboração de 13 pacientes com idades entre 12 a 40 anos, sendo na maioria pacientes adolescentes que utilizavam dispositivo ortodôntico fixo. O tamanho da amostra foi determinado de acordo com o mínimo necessário para um estudo estereológico. Desse modo, havia necessidade de 10 peças por período estudado - 5 do lado teste e 5 do controle - para que as aferições pudessem preencher os requisitos das análises estatísticas. A desistência de um dos pacientes que se submeteria à biópsia, na área superior e inferior, em períodos diferentes, fez com que os grupos de 7 e 15 dias ficassem apenas com 8 peças. A região anterior (canino a canino) foi escolhida pela acessibilidade e facilidade de observação ${ }^{37}$.

O aparelho de laser utilizado foi o diodo de GaAlAs - $670 \mathrm{~nm}$, comprimento de onda no espectro vermelho, com menor poder de penetração no tecido, portanto adequado ao tratamento de feridas cirúrgicas abertas ${ }^{54}$. Os lasers de GaAlAs com comprimento de onda de 630-670nm estão indicados para tratamento de úlceras, herpes e cicatrização de feridas ${ }^{54}$.

A densidade de energia utilizada foi de $4 \mathrm{~J} / \mathrm{cm}^{2}$, baseada em outros trabalhos realizados em humanos ${ }^{2,14,33}$ e animais ${ }^{23}$. Salienta-se que a dose recomendada pelo fabricante para efeitos reparativos/regenerativos é de 3 a $6 \mathrm{~J} / \mathrm{cm}^{2}$.

Em relação à frequiência de aplicação do laser, há uma enorme variação na literatura. Alguns autores aplicaram o laser $œ m$ intervalos de 3 dias $^{2,43}$, outros, diariamente $^{3,18,23,42,63}$, duas vezes por semana ${ }^{32,33}$, três vezes por semana ${ }^{21,31}$, ou ainda, aplicação única logo após a cirurgia ${ }^{6,7,10,14,28,35}$. 
Para este estudo, a aplicação do laser foi feita em intervalos de 2 dias durante uma semana, totalizando 4 sessões, ou seja, um período médio entre os utilizados em outros trabalhos e dentro dos padrões indicados pelo fabricante, que recomenda aplicações de 2 a 3 vezes por semana.

Convém salientar que o intuito deste estudo foi testar um protocolo de tratamento que pudesse ser utilizado no consultório odontológico. Desse modo, aplicações diárias foram descartadas porque dificultariam o retorno do paciente à clínica somente para sessões de laser. Em relação à aplicação única, esta foi evitada pelo fato de o trabalho de SKINNER $^{46}$ ter mostrado que as irradiações repetidas geram maior taxa de proliferação celular nos tecidos. A esse respeito, salienta-se que cada tecido possui o início da atividade mitótica em um período do processo reparacional, que deve ser estimulado pelo laser. Assim, por exemplo, no tecido conjuntivo, o pico de proliferação celular ocorre aos 3 dias de pós-operatório ${ }^{39}$. No atual estudo, o período de aplicação durante uma semana de pós-operatório foi escolhido por ser o tempo para as feridas estarem completamente reepitelizadas e para que a irradiação agisse durante a fase proliferativa do processo cicatricial.

Apesar de o modo de aplicação - pontual ou varredura - muitas vezes não ser citado na metodologia de trabalhos publicados, optourse pela aplicação pontual com base em alguns estudos ${ }^{7,21}$ que fizeram aplicação do laser em vários pontos na borda de feridas extensas como no caso do presente trabalho. O laser foi aplicado à distância de $1 \mathrm{~mm}$ (modo de não contato) para evitar contato com a ferida cirúrgica e, conseqüentemente, dor ao paciente.

O modelo experimental de utilização de lados teste e controle, no mesmo paciente, foi baseado na maioria dos estudos intrabucais em humanos $2,4,10,14,35,43$, e 
também estudos em animais $3,6,18,23,32,33,42$. Desse modo, em humanos se evitam variações individuais como hábito alimentar, higiene, metabolismo e comportamento pessoal, além de facilitar a análise comparativa entre os lados.

A análise clínica visual por imagens fotográficas, feita por cinco examinadores, mostrou uma tendência de escolha ora por um ora por outro lado como o mais bem cicatrizado até o período de 21 dias. (TABELA 1 e FIGURA 22). Nos períodos subseqüentes, a igualdade entre ambos os lados foi a escolha dos observadores. Esse fato sugere que o laser possa ter ação nos períodos iniciais do processo cicatricial. Os resultados desta pesquisa diferem sobremaneira do estudo feito por $\mathrm{AMORIM}^{2}$, no qual o grupo laser foi escolhido como mais bem cicatrizado dentro do período de 7 a 35 dias, com concordância substancial entre os examinadores. No presente trabalho houve baixa concordância entre os examinadores (TABELA 2), apesar do cuidado na escolha de periodontistas com o mesmo nível de formação e do estabelecimento de parâmetros para avaliação da cicatrização como cor, textura e contorno gengival. Notou-se que cada observador deu maior importância a um dos parâmetros e não ao conjunto e, como conseqüência, houve heterogeneidade nas avaliações.

Uma dificuldade encontrada foi a padronização dos eslaides. Apesar da igualdade na aproximação das fotos, algumas tiveram foco em pontos diferentes, iluminação em áreas variadas. A área a ser fotografada foi sempre seca com jatos de ar, mas nos períodos iniciais o exsudato na ferida cirúrgica deixou as fotografias com brilho. Todos esses fatores citados podem ter mascarado a real situação clínica obtida e gerado a discordância entre os examinadores. Idealmente, todos os examinadores deveriam observar clinicamente in loco a cicatrização e não através de 
fotografias que estão sujeitas, como já salientado, a grandes variações. Nesse sentido é pertinente informar que o cirurgião que acompanhou todos os períodos pósoperatórios teve uma visão clínica distinta dos examinadores. Assim, na maioria das vezes, foi observado que o lado teste se mostrava mais avançado no processo cicatricial em relação ao controle, mais marcadamente durante os períodos de 2 e 4 dias, quando se retirava o cimento cirúrgico para aplicação do laser. Essas observações sugerem que o laser possa ter uma maior influência nos eventos precoces de inflamação e de formação do tecido de granulação que ocorrem nos primeiros dias após a cirurgia e que não foram avaliados neste estudo. A variação no “n” da TABELA 1 e FIGURA 22 se deve à ausência de alguns eslaides devido à falta do paciente no dia do controle ou problemas com iluminação da fotografia.

No período de 60 dias, alguns pacientes já apresentavam ligeiro acúmulo de placa na margem gengival, mas o tecido não estava clinicamente inflamado. Neste caso, foi feita profilaxia cuidadosa e as orientações de higiene foram reforçadas. Essa ocorrência não modificou a análise dos observadores, que estudaram o tecido gengival como um todo não se restringindo a pequenas áreas, mesmo porque, neste e em outros períodos, a biópsia tinha sido praticada próxima da área de papila entre lateral e canino. Os observadores foram alertados dessa área em cicatrização e avaliaram outros sítios.

A reparação da ferida ocorreu de forma normal e esperada em todos os pacientes. De acordo com RAMFJORD ${ }^{39}$, logo nos primeiros dias após a cirurgia ocorre inflamação aguda dominada por polimorfonucleares (PMN), cujo número diminui conforme a ferida é recoberta por epitélio e, concomitantemente, há um aumento no número de células mononucleadas ${ }^{39}$. No presente trabalho, verificourse 
que o número de polimorfonucleares ainda é maior aos 7 dias e, já aos 15 dias, há predominância de células inflamatórias mononucleadas. (TABELAS 3 e 4/FIGURA $30)$.

Num processo de regeneração do epitélio gengival, sabe-se que o pico de atividade mitótica do epitélio ocorre entre 24 e 48 h após a cirurgia, juntamente com a sua migração, que ocorre entre uma camada de tecido necrótico recoberta por uma faixa de polimorfonucleares e o tecido saudável. Essa faixa de polimorfonucleares protege o tecido conjuntivo da invasão bacteriana ${ }^{22,20,39}$. Desse modo, em todos os pacientes a ferida já estava completamente reepitelizada aos 7 dias de pós-operatório, portanto, de acordo com trabalhos que acompanharam a cicatrização gengival em humanos $^{38,49}$. Segundo RAMFJORD ${ }^{38}$, o epitélio migra $0,5 \mathrm{~mm}$ ao dia, das bordas para o centro da ferida. Assim, dependendo do tamanho da lesão, a reepitelização pode se estender até 15 dias $^{13,22,36,55}$. Segundo LISTGARTEN ${ }^{29}$, a cicatrização em humanos pode variar, em relação ao tempo, dependendo da higiene oral e susceptibilidade à doença periodontal.

Em estudos de microscopia eletrônica, a diferenciação do epitélio ceratinizado ocorre pela formação e acúmulo de microfilamentos de ceratina nas células superficiais, estreitamento dos espaços intercelulares e presença de grânulos de cerato-hialina ${ }^{22}$. Salienta-se que na presente pesquisa, o estrato granuloso contendo células exibindo esses grânulos foi observado no $7^{\circ}$ dia pós-cirúrgico (FIGURAS 23a e 23b ) e, nos períodos subseqüentes, esse estrato não estava mais presente, sugerindo que os grânulos de cerato-hialina são importantes no início de ceratinização do epitélio. A formação do estrato córneo ocorre entre o $7^{\circ}$ e $16^{\circ}$ dia pós-cirurgia $^{22,38}$. Na atual pesquisa, no período de 7 dias, o estrato córneo 
paraceratinizado já estava presente, mas ainda exibia características de imaturidade. Um estrato córneo totalmente maduro só foi observado a partir dos 21 dias póscirurgia. (FIGURAS 25a e 25b). Neste trabalho, todos os pacientes possuíam mucosa paraceratinizada, característica da mucosa oral na maioria dos $\operatorname{casos}^{49}$.

A observação clínica mostrou que a ferida, apesar de uma coloração mais avermelhada, parece curada aos 15 dias, devido ao seu completo recobrimento por epitélio. (FIGURAS 18a e 18b) No entanto, o tecido conjuntivo da lâmina própria mostra, histologicamente, uma maturação mais lenta e tardia. Segundo dados da literatura, o pico de atividade proliferativa nesse tecido ocorre no terceiro dia após a cirurgia $^{39}$. Essa atividade de produção de novas fibras colágenas e sua remodelação inicia-se nas regiões mais distantes da borda da ferida e se espalha por toda a área operada somente após o recobrimento total por epitélio ${ }^{39}$. Nos períodos iniciais, há grande vasodilatação com aumento da circulação no local, a qual diminui com a evolução do processo cicatricial e volta ao normal por volta do $16^{\circ} \mathrm{dia}^{36}$. Por outro lado, a atividade proliferativa dos fibroblastos se mantém alta, geralmente até o $30^{\circ}$ $\operatorname{dia}^{39,50}$. No atual trabalho, nota-se que o número de fibroblastos aumentou ao longo do tempo, conforme se observa nas TABELA 3 e 4 e FIGURA 29. RAMFJORD ${ }^{39}$ constatou que a formação de colágeno é gradual durante as 3 a 4 semanas após a cirurgia e se inicia com a diminuição da vascularização, sendo que com 35 dias o tecido já está praticamente maduro. A pequena queda no número de fibroblastos, aos 60 dias pós-cirúrgicos, no grupo teste, (FIGURA 29/ TABELA 4), pareceu ser casual e foge à lógica do processo.

Devido à maturação mais tardia do tecido conjuntivo optourse, neste trabalho, por estudar histologicamente principalmente os períodos iniciais de 7, 14 e 21 dias. 
Neste intervalo de tempo há uma grande atividade proliferativa no tecido, que o torna sujeito a sofrer um maior efeito do laser. Nos períodos de 30 e 45 dias já não ocorrem mudanças muito significativas, desse modo, o período de 60 dias foi escolhido por possuir todas as características de mucosa normal já estabelecidas.

A formação do sulco gengival, e conseqüentemente a reconstituição das distâncias biológicas, se inicia aos 15 dias e se completa entre 35 a 44 dias de pósoperatório $^{13,38,55}$. Clinicamente esse processo se dá pela ligeira migração da margem gengival para coronal, que pode ser observada nas FIGURAS 18a a 21 b quando comparadas às figuras $17 \mathrm{a}$ e $17 \mathrm{~b}$.

Os resultados aqui descritos mostraram clínica e histologicamente que não foi possível afirmar que a utilização do laser GaAlAs - 670nm, dentro dos padrões estabelecidos, tenha acelerado a cicatrização em relação ao lado controle. Esses

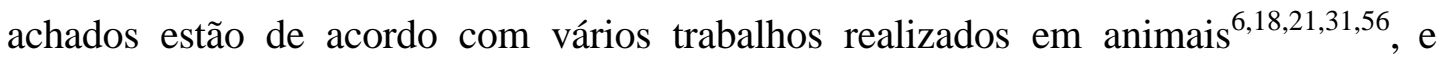
também em humanos ${ }^{7,14,28,43}$, e que contrastam com pesquisas que mostraram efeitos benéficos da terapia com laser em baixa intensidade na aceleração da cicatrização de feridas. Estas últimas foram, na sua maioria, feitas em ratos ${ }^{3,23,32,63}$ ou in vitro, com cultura de células ${ }^{17,26,30,46}$.

Interpretar resultados de laboratório sobre os efeitos da terapia com laser em baixa intensidade é difícil, devido à diversidade de modelos animais e parâmetros utilizados. Os ratos são sempre utilizados para pesquisa por serem o modelo mais prático, barato, de fácil criação e mais resistente às cirurgias e anestesia. Além de ter um metabolismo acelerado, têm as feridas completamente cicatrizadas em 2 a 3 semanas $^{56}$. Esses animais, entretanto, não são os modelos mais adequados porque possuem pele fina e suas feridas cicatrizam predominantemente por contração da 
ferida em vez de reepitelização da mesma, o que é mais comum na pele humana ${ }^{25,31}$. Para estudos em Odontologia, seriam menos adequados ainda, pois a mucosa ceratinizada praticamente não sofre esse tipo de contração. Desse modo, nenhuma conclusão obtida nesses estudos poderia ser extrapolada diretamente para humanos. Alguns pesquisadores sugerem estudos em porcos, devido a sua a pele mais espessa, mas, justamente por esse fato, a profundidade de penetração do laser seria bem menor, e os resultados também poderiam ser distorcidos ${ }^{25,56}$.

Por outro lado, os estudos com culturas de célula parecem ser um campo promissor nessa área. Trabalhos com cultura de células têm mostrado efeitos positivos do laser em vários mecanismos biológicos, como aumento da proliferação de fibroblastos ${ }^{30,26}$, ceratinócitos ${ }^{17,51}$, aumento na produção de fatores de crescimento $^{62}$ e inibição da produção de prostaglandinas ${ }^{45}$. Ainda assim, os resultados em estudos in vitro devem ser analisados com cautela, primeiro porque como a célula está sendo diretamente irradiada, há necessidade de menores doses de laser, e segundo, porque em humanos há interações do laser com outros componentes do tecido, e mesmo com o organismo como um todo. A esse respeito, é preciso ter em mente que os mecanismos envolvidos no processo cicatricial são complexos, dependendo de uma interação entre as atividades dos fibroblastos, da matriz extracelular e de diversos fatores produzidos pelas células inflamatórias.

Outros trabalhos em humanos também não mostraram grandes efeitos benéficos do laser na cicatrização ${ }^{7,10,14,28,43}$. Muitas dessas investigações utilizaram um dos lados do paciente como controle, inclusive o presente estudo. Esse modelo de "boca dividida" é muito criticado por alguns autores que defendem a teoria dos efeitos sistêmicos do laser ${ }^{25,53,54}$. Estes sugerem que a irradiação geraria a liberação 
de substâncias na corrente sangüínea que iriam atingir áreas distantes do local irradiado $^{6,19,26,42}$. Nesse sentido, alguns trabalhos em cultura de células mostraram aumento na produção de fatores de crescimento ${ }^{3,62}$ e diminuição de mediadores da inflamação $^{45}$ após irradiação com laser. Por outro lado, apesar de haver críticas a alguns trabalhos que não mostraram ação positiva do laser utilizando lado teste e controle em pacientes ou animais, alguns estudos utilizando este mesmo modelo obtiveram resultados melhores no lado onde foi aplicado laser ${ }^{2,10,23,33}$. Nesses casos, provavelmente o lado irradiado responde melhor por receber concomitantemente os efeitos locais e sistêmicos do laser. Se os efeitos sistêmicos realmente existirem, devemos encará-los como um benefício ao paciente, já que suas propriedades de cura irão atingir outras partes do organismo.

Um outro ponto a ser discutido, e que pode explicar a falta de resultados significantes neste estudo, é que a terapia com laser tem mais efeitos em tecidos afetados por condição patológica ${ }^{25,42,53,54}$. TUNÈR; HODE $^{54}$ sugerem que o laser afeta diretamente o sistema imune e, portanto, organismos saudáveis não respondem tão bem ao laser porque a cicatrização se processa dentro de parâmetros normais. Nesse sentido, uma pesquisa in vitro feita por STEINLECHNER ${ }^{51}$ mostrou que ceratinócitos humanos cultivados em ambiente pobre em nutrientes tiveram maior taxa de proliferação após irradiação com laser em comparação aos que tinham condições normais de nutrição. Trabalhos realizados em ratos diabéticos mostraram que animais com essa doença sistêmica tiveram fechamento mais rápido das feridas ${ }^{63}$ e maior produção de fator de crescimento fibroblástico (FGF) ${ }^{3}$. Células imaturas, ou em estágio embrionário, têm sua taxa de divisão mitótica aumentada após estímulo com laser quando comparadas a fibroblastos maduros ${ }^{46}$. Por outro lado, ratos que 
receberam altas doses de raio $\mathrm{X}$, antes da cirurgia, não responderam à terapia laser, ou seja, a radiação ionizante atrasou o processo cicatricial e o laser não reverteu esse quadro $^{31,56}$.

A cirurgia de gengivoplastia é um procedimento cirúrgico relativamente simples, que se restringe apenas ao tecido mole e tem excelente pós-operatório na maioria dos casos. Esse fato associado à juventude e à ausência de doenças sistêmicas dos pacientes participantes deste estudo, podem justificar uma resposta não tão evidente ao laser. Essa justificativa talvez seja mais relevante que um possível efeito sistêmico do laser, embora este também possa estar presente. AREMBAND; $\mathrm{WADE}^{4}$ realizaram cirurgias de gengivectomia com bisturi da forma convencional e com bisturi elétrico utilizando os dois lados do paciente para comparação. O acompanhamento clínico e histológico após 7, 15 e 21 dias póscirúrgicos não mostrou diferenças significativas entre as técnicas. Esse estudo, à semelhança do atual, mostra que a cicatrização da gengivoplastia é simples, rápida e não exibe diferenças mesmo quando técnicas diversas são utilizadas.

Ao analisar todos os trabalhos revisados, neste estudo, há que se admitir que a documentação científica da terapia com laser em baixa intensidade ainda está incompleta. Apesar de a literatura mostrar que há influência positiva do laser em um grande número de processos biológicos, muitos trabalhos ainda são necessários para se estabelecer um protocolo de aplicação. Há necessidade de se padronizar densidade, potência, comprimento de onda, freqüência e modo de aplicação do laser específicos para cada caso. Não se pode comparar estudos porque esses parâmetros são extremamente variados.

Este estudo procurou analisar os efeitos do laser em humanos, da maneira 
convencional, que é a avaliação clínica, e com uma avaliação mais específica (histológica e morfométrica) para confirmar os achados clínicos. Porém, no período analisado, não se observou diferença entre os grupos. Para pesquisar os efeitos do laser nos eventos iniciais da cicatrização, talvez fossem necessários estudos que observassem as primeiras horas e primeiros dias do processo cicatricial. Pesquisas em humanos, que avaliassem a produção de fatores de crescimento ou a inibição de mediadores da inflamação, talvez pudessem confirmar os efeitos reais do laser nos tecidos. Porém, esses trabalhos têm uma metodologia complexa, dentro de um campo de pesquisa relativamente novo. 
7 CONCLUSÕES 


\section{CONCLUSÕES}

Diante dos resultados obtidos, no período de 7 a 60 dias de pós-operatório, considerando-se a metodologia empregada, é possível concluir que:

1 - Clinicamente o processo cicatricial não diferiu entre as áreas experimental e controle.

2 - Histomorfometricamente, o laser não influenciou o processo de regeneração epitelial e reparação conjuntiva. 
ANEXOS 


\section{ANEXO 1 \\ CARTA DE INFORMAÇÃO AO PACIENTE}

Prezado Sr.(a)

A pesquisa “Avaliação clínica e histológica dos efeitos do laser em baixa intensidade (GaAlAs) na cicatrização gengival após cirurgias de gengivoplastia em humanos" constitui o trabalho de tese de mestrado da C.D. Carla Andreotti Damante, sob orientação do Prof. Dr. Sebastião Luiz Aguiar Greghi e será desenvolvida nas dependências físicas da Disciplina de Periodontia da Faculdade de Odontologia de Bauru - USP.

Os itens abaixo incluem esclarecimentos sobre os procedimentos a serem efetuados e por isso recomendamo-los à leitura cuidadosa:

a) Esta pesquisa justifica-se pela importância de se oferecer aos pacientes portadores de hiperplasia gengival (gengiva cresce para cima do dente) um tratamento eficaz que resulte na restauração da estética e função. O objetivo deste trabalho compreende a avaliação clínica e histológica da cicatrização da área após a aplicação do laser em baixa intensidade.

b) $\mathrm{O}$ desconforto proveniente dos tratamentos e acompanhamentos ocorre em graus variáveis de acordo com cada paciente. De acordo com trabalhos já publicados, o laser acelera a cicatrização e diminui o desconforto pós-operatório. Entretanto, não pode ser descartada a possibilidade de não-ocorrência desses resultados, o que não traria nenhum prejuízo ao paciente.

c) Entre os métodos alternativos ao oferecido nesta pesquisa, inclui-se a terapia de manutenção periodontal, tratamento de qualquer outro problema periodontal existente e encaminhamento para tratamentos odontológicos necessários. 
d) Os pacientes serão acompanhados durante o período pós-operatório, para controle, sendo avaliados clinicamente durante 30 dias de experimento e, histologicamente, por meio de biópsias uma única vez em cada sítio experimental durante esse período de observação. A assistência e acompanhamento estarão sob a responsabilidade do pesquisador.

e) Durante o curso da pesquisa, o paciente será informado sobre todos os procedimentos nele realizados. Além disso, a ele estarão reservados todos os direitos de esclarecimentos de dúvidas a respeito do tratamento, quantas vezes necessárias.

f) O paciente tem a liberdade de se recusar a participar ou retirar seu consentimento, em qualquer fase da pesquisa, sem penalização alguma e sem prejuízo ao seu cuidado.

g) Ao paciente está assegurado o sigilo dos dados confidenciais envolvidos na pesquisa. Na eventualidade de ocorrência de danos decorrentes da pesquisa, os pesquisadores são responsáveis pela assistência integral necessária à promoção do reparo de tais danos.

Bauru, de de 


\title{
ANEXO 2 \\ UNIVERSIDADE DE SÃO PAULO \\ FACULDADE DE ODONTOLOGIA DE BAURU \\ COMITÊ DE ÉTICA EM PESQUISA \\ TERMO DE CONSENTIMENTO LIVRE E ESCLARECIDO
}

\begin{abstract}
Pelo presente instrumento que atende às exigências legais, o senhor(a) portador de cédula de identidade $\mathrm{n}^{\mathrm{o}}$ , após leitura minuciosa da CARTA DE INFORMAÇÃO
\end{abstract}

AO PACIENTE, devidamente explicada pelo(s) profissionais em seus mínimos detalhes, ciente dos serviços e procedimentos aos quais será submetido, não restando quaisquer dúvidas a respeito do lido e do explicado, firma seu CONSENTIMENTO LIVRE E ESCLARECIDO em concordância em participar da pesquisa proposta no que lhe é cabível conforme a CARTA DE INFORMAÇÃO AO PACIENTE.

Fica claro que o paciente e/ou seu representante legal pode a qualquer momento retirar seu CONSENTIMENTO LIVRE E ESCLARECIDO e deixar de participar do estudo alvo da pesquisa e, ciente de que todo trabalho realizado torna-se informação confidencial guardada por força do sigilo profissional (Art. $9^{\circ}$ do Código de Ética Odontológica).

Por estarem entendidos e conformados, assinam o presente termo.

Bauru, de de

Assinatura do paciente

Assinatura do pesquisador responsável

Carla Andreotti Damante 


\section{ANEXO 3}

ANÁLISE CLÍNICA - VISUAL ESLAIDES

Observador:

\begin{tabular}{|c|c|c|c|}
\hline Paciente 1 -SUP & $\begin{array}{c}\text { Lado } \\
\text { D }\end{array}$ & $\begin{array}{c}\text { Lado } \\
\text { E }\end{array}$ & Iguais \\
\hline 7 dias & & & \\
\hline 15 dias & & & \\
\hline 21 dias & & & \\
\hline 30 dias & & & \\
\hline 60 dias & & & \\
\hline
\end{tabular}

\begin{tabular}{|c|c|c|c|}
\hline Paciente 2 -INF & $\begin{array}{c}\text { Lado } \\
\text { D }\end{array}$ & $\begin{array}{c}\text { Lado } \\
\text { E }\end{array}$ & Iguais \\
\hline 7 dias & & & \\
\hline 15 dias & & & \\
\hline 21 dias & & & \\
\hline 30 dias & & & \\
\hline 60 dias & & & \\
\hline
\end{tabular}

\begin{tabular}{|c|c|c|c|}
\hline Paciente 1 -INF & $\begin{array}{c}\text { Lado } \\
\text { D }\end{array}$ & $\begin{array}{c}\text { Lado } \\
\text { E }\end{array}$ & Iguais \\
\hline 7 dias & & & \\
\hline 15 diad & & & \\
\hline 21 dias & & & \\
\hline 30 dias & & & \\
\hline 60 dias & & & \\
\hline
\end{tabular}

\begin{tabular}{|c|c|c|c|}
\hline Paciente 3 -SUP & $\begin{array}{c}\text { Lado } \\
\text { D }\end{array}$ & $\begin{array}{c}\text { Lado } \\
\text { E }\end{array}$ & Iguais \\
\hline 7 dias & & & \\
\hline 15 dias & & & \\
\hline 21 dias & & & \\
\hline 30 dias & & & \\
\hline 60 dias & & & \\
\hline
\end{tabular}

\begin{tabular}{|c|c|c|c|}
\hline Paciente 2 -SUP & $\begin{array}{c}\text { Lado } \\
\text { D }\end{array}$ & $\begin{array}{c}\text { Lado } \\
\text { E }\end{array}$ & Iguais \\
\hline 7 dias & & & \\
\hline 15 dias & & & \\
\hline 21 dias & & & \\
\hline 30 dias & & & \\
\hline 60 dias & & & \\
\hline
\end{tabular}

\begin{tabular}{|c|c|c|c|}
\hline Paciente 4 -SUP & $\begin{array}{c}\text { Lado } \\
\text { D }\end{array}$ & $\begin{array}{c}\text { Lado } \\
\text { E }\end{array}$ & Iguais \\
\hline 7 dias & & & \\
\hline 15 dias & & & \\
\hline 21 dias & & & \\
\hline 30 dias & & & \\
\hline 60 dias & & & \\
\hline
\end{tabular}




\section{ANEXO 4}

TABELA - Dados estatísticos da análise morfométrica durante os períodos analisados.

\begin{tabular}{|c|c|c|c|c|c|c|c|c|}
\hline & \multirow[b]{2}{*}{ TEMPO } & \multicolumn{2}{|c|}{ Teste } & \multicolumn{2}{|c|}{ Controle } & \multirow[t]{2}{*}{$\mathrm{t}$} & \multirow[t]{2}{*}{$\mathbf{p}$} & \\
\hline & & Média & $\mathrm{DP}$ & Média & DP & & & \\
\hline \multicolumn{9}{|c|}{ Densidade de volume dos estratos do epitélio (\%) } \\
\hline \multirow{4}{*}{ Córneo } & 7 & 24,08 & 2,94 & 21,67 & 5,08 & 0,95 & 0,41 & $\mathrm{~ns}$ \\
\hline & 15 & 26,60 & 9,40 & 24,86 & 6,52 & 0,52 & 0,64 & ns \\
\hline & 21 & 23,62 & 8,37 & 24,65 & 7,38 & $-0,62$ & $\mathbf{0 , 5 6}$ & ns \\
\hline & 60 & 22,51 & 4,01 & 21,12 & 3,88 & 1,39 & 0,24 & $\mathrm{~ns}$ \\
\hline \multirow{4}{*}{ Espinhoso } & 7 & 53,44 & 2,91 & 53,92 & 2,56 & $-0,23$ & 0,83 & $\mathrm{~ns}$ \\
\hline & 15 & 54,32 & 9,55 & 58,34 & 4,46 & $-0,73$ & 0,51 & ns \\
\hline & 21 & 58,01 & 8,60 & 56,88 & 6,29 & 0,32 & 0,76 & $\mathrm{~ns}$ \\
\hline & 60 & 56,60 & 6,81 & 56,78 & 2,69 & $-0,05$ & 0,96 & $\mathrm{~ns}$ \\
\hline \multirow{4}{*}{ Basal } & 7 & 22,47 & 2,29 & 24,40 & 3,97 & $-2,28$ & 0,11 & $\mathrm{~ns}$ \\
\hline & 15 & 19,07 & 8,41 & 16,79 & 2,94 & 0,50 & 0,65 & $\mathrm{~ns}$ \\
\hline & 21 & 18,36 & 2,71 & 18,46 & 4,18 & $-0,04$ & 0,97 & $\mathrm{~ns}$ \\
\hline & 60 & 20,88 & 8,25 & 22,05 & 2,91 & $-0,41$ & 0,70 & $\mathrm{~ns}$ \\
\hline \multicolumn{9}{|c|}{ Relação luminal e basal } \\
\hline & 7 & $\mathbf{0 , 4 0}$ & 0,13 & 0,44 & 0,17 & $-1,80$ & $\mathbf{0 , 1 7}$ & $\mathrm{ns}$ \\
\hline & 15 & $\mathbf{0 , 5 0}$ & 0,19 & $\mathbf{0 , 5 3}$ & 0,15 & $-0,25$ & $\mathbf{0 , 8 1}$ & $\mathrm{ns}$ \\
\hline & 21 & $\mathbf{0 , 4 1}$ & 0,15 & $\mathbf{0 , 5 0}$ & 0,19 & $-2,32$ & $\mathbf{0 , 0 8}$ & ns \\
\hline & 60 & $\mathbf{0 , 3 3}$ & 0,12 & $\mathbf{0 , 2 8}$ & 0,08 & 2,06 & $\mathbf{0 , 1 1}$ & $\mathrm{ns}$ \\
\hline \multicolumn{9}{|c|}{ Espessura do epitélio $(\mu \mathrm{m})$} \\
\hline & 7 & 279,67 & 70,07 & 260,58 & 23,10 & 0,52 & 0,63 & $\mathrm{~ns}$ \\
\hline & 15 & 311,91 & 102,36 & 287,02 & 33,50 & 0,56 & 0,61 & $\mathrm{~ns}$ \\
\hline & 21 & 366,04 & 80,85 & 306,64 & 69,60 & 1,57 & 0,19 & $\mathrm{~ns}$ \\
\hline & 60 & 367,71 & 83,32 & 393,54 & 29,83 & $-0,90$ & 0,41 & $\mathrm{~ns}$ \\
\hline \multicolumn{9}{|c|}{$\mathrm{N}^{0}$ de células/ $\mathrm{mm}^{3}$ do conjuntivo } \\
\hline \multirow{4}{*}{ Fibroblastos } & 7 & 613,89 & 85,97 & 519,99 & 88,46 & 2,04 & 0,13 & $\mathrm{~ns}$ \\
\hline & 15 & 858,89 & 160,68 & $\mathbf{7 8 2 , 7 7}$ & 119,28 & 2,69 & 0,74 & $\mathrm{~ns}$ \\
\hline & 21 & 946,11 & 188,99 & $\mathbf{8 5 7 , 7 7}$ & 150,00 & 1,64 & $\mathbf{0 , 2 0}$ & $\mathrm{ns}$ \\
\hline & 60 & 777,33 & 51,60 & 932,44 & 171,93 & $-1,84$ & 0,14 & $\mathrm{~ns}$ \\
\hline \multirow{4}{*}{ Mononucleares } & 7 & $\mathbf{2 0 , 5 5}$ & 2,12 & 12,77 & 3,79 & 2,94 & 0,06 & $\mathrm{~ns}$ \\
\hline & 15 & 41,11 & 26,69 & 43,89 & 33,02 & $-0,11$ & 0,92 & ns \\
\hline & 21 & 28,88 & 12,69 & 23,33 & 11,54 & 0,83 & 0,46 & $\mathrm{~ns}$ \\
\hline & 60 & 4,89 & 3,65 & 3,55 & 5,57 & 0,58 & $\mathbf{0 , 5 9}$ & $\mathrm{ns}$ \\
\hline \multirow{4}{*}{$\begin{array}{l}\text { Polimorfo - } \\
\text { nucleares }\end{array}$} & 7 & 6,11 & 4,92 & 3,33 & 2,86 & 0,99 & 0,39 & $\mathrm{~ns}$ \\
\hline & 15 & 1,11 & 1,28 & 2,22 & 3,14 & $-0,57$ & 0,60 & $\mathrm{~ns}$ \\
\hline & 21 & 1,11 & 2,22 & 1,11 & 1,28 & 0,00 & 1,00 & $\mathrm{~ns}$ \\
\hline & 60 & 0,44 & 0,99 & $\mathbf{0 , 0 0}$ & 0,00 & 1,00 & $\mathbf{0 , 3 7}$ & $\mathrm{ns}$ \\
\hline
\end{tabular}


Anexos

\begin{tabular}{|c|c|c|c|c|c|c|c|c|}
\hline \multicolumn{9}{|c|}{ Volume nuclear e celular dos estratos do epitélio $\left(\mu \mathrm{m}^{3}\right)$} \\
\hline & 7 & 193,27 & 41,15 & 211,89 & 47,19 & $-1,60$ & $\mathbf{0 , 2 0}$ & ns \\
\hline \multirow[t]{4}{*}{ Basal núcleo } & 15 & 197,63 & 14,75 & $\mathbf{2 0 7 , 8 7}$ & 44,44 & $-0,55$ & 0,62 & ns \\
\hline & 21 & 202,66 & 43,25 & 219,83 & 57,43 & $-1,40$ & $\mathbf{0 , 2 2}$ & ns \\
\hline & 60 & 212,90 & 32,73 & 218,18 & 45,82 & $-0,37$ & $\mathbf{0 , 7 2}$ & ns \\
\hline & 7 & 415,45 & 70,45 & 468,97 & 159,55 & $-0,76$ & $\mathbf{0 , 5 0}$ & ns \\
\hline \multirow{4}{*}{$\begin{array}{l}\text { Basal } \\
\text { citoplasma }\end{array}$} & 15 & 462,86 & 24,82 & 487,04 & 111,23 & $-0,52$ & 0,63 & ns \\
\hline & 21 & 435,92 & 51,33 & 441,70 & 114,77 & $-0,12$ & 0,90 & ns \\
\hline & 60 & 414,76 & 83,64 & 416,31 & 77,51 & $-0,03$ & 0,97 & ns \\
\hline & 7 & 608,70 & 71,76 & 680,86 & 187,26 & $-0,90$ & 0,43 & ns \\
\hline \multirow[t]{4}{*}{ Basal célula } & 15 & 660,50 & 38,76 & 694,91 & 153,30 & $-0,54$ & 0,62 & ns \\
\hline & 21 & 638,58 & 82,61 & 661,54 & 169,54 & $-0,42$ & 0,69 & ns \\
\hline & 60 & 627,66 & 103,41 & 634,49 & 123,07 & $-0,10$ & 0,91 & $\mathrm{~ns}$ \\
\hline & 7 & 318,25 & 26,31 & 316,42 & 37,15 & 0,08 & 0,93 & $\mathrm{~ns}$ \\
\hline \multirow{4}{*}{$\begin{array}{l}\text { Espinhoso } \\
\text { núcleo }\end{array}$} & 15 & 296,14 & 44,44 & 295,17 & 42,09 & 0,06 & 0,95 & ns \\
\hline & 21 & 240,52 & 33,78 & 274,12 & 73,92 & $-1,73$ & 0,15 & $\mathrm{~ns}$ \\
\hline & 60 & 266,82 & 38,40 & 279,85 & 25,86 & $-0,58$ & $\mathbf{0 , 5 8}$ & ns \\
\hline & 7 & 2902,00 & 504,02 & 3346,84 & 878,95 & $-0,93$ & 0,41 & ns \\
\hline \multirow{4}{*}{$\begin{array}{l}\text { Espinhoso } \\
\text { citoplasma }\end{array}$} & 15 & 1908,17 & 382,22 & 2037,90 & 670,55 & $-0,32$ & 0,76 & ns \\
\hline & 21 & 1959,47 & 371,87 & 2240,33 & 991,46 & $-0,48$ & 0,65 & ns \\
\hline & 60 & 1697,21 & 366,47 & 2005,42 & 372,76 & $-1,59$ & 0,18 & ns \\
\hline & 7 & 3220,25 & 516,49 & 3663,20 & 895,39 & $-0,90$ & 0,43 & ns \\
\hline \multirow{4}{*}{$\begin{array}{l}\text { Espinhoso } \\
\text { célula }\end{array}$} & 15 & 2204,31 & 415,63 & 2333,07 & 687,44 & $-0,32$ & 0,76 & ns \\
\hline & 21 & 2200,00 & 361,98 & 2514,46 & 1056,94 & $-0,53$ & 0,62 & ns \\
\hline & 60 & 1864,03 & 513,15 & 2285,28 & 381,84 & $-1,45$ & 0,22 & $\mathrm{~ns}$ \\
\hline & 7 & 47,84 & 12,55 & 37,41 & 13,15 & 1,58 & 0,21 & $\mathrm{~ns}$ \\
\hline \multirow{4}{*}{$\begin{array}{l}\text { Córneo } \\
\text { núcleo }\end{array}$} & 15 & 41,40 & 16,26 & 33,46 & 12,29 & 1,14 & $\mathbf{0 , 3 3}$ & ns \\
\hline & 21 & 30,96 & 9,44 & 33,71 & 10,22 & $-0,62$ & 0,56 & ns \\
\hline & 60 & 30,47 & 10,66 & 30,66 & 9,21 & $-0,03$ & 0,97 & ns \\
\hline & 7 & 1487,25 & 432,81 & 1332,53 & 460,53 & 0,71 & 0,52 & ns \\
\hline \multirow{4}{*}{$\begin{array}{l}\text { Córneo } \\
\text { citoplasma }\end{array}$} & 15 & 1110,70 & 447,82 & 922,28 & 356,66 & 1,24 & $\mathbf{0 , 3 0}$ & $\mathrm{ns}$ \\
\hline & 21 & 733,10 & 285,31 & 1013,56 & 323,56 & $-2,42$ & $\mathbf{0 , 0 7}$ & ns \\
\hline & 60 & 716,61 & 253,55 & 804,61 & 168,16 & $-0,58$ & $\mathbf{0 , 5 8}$ & ns \\
\hline & 7 & 1535,25 & 442,63 & 1369,94 & 473,16 & 0,74 & 0,51 & ns \\
\hline \multirow{3}{*}{$\begin{array}{l}\text { Córneo } \\
\text { célula }\end{array}$} & 15 & 1152,11 & 463,81 & 955,72 & 368,43 & 1,23 & $\mathbf{0 , 3 0}$ & ns \\
\hline & 21 & 764,07 & 294,47 & 1047,28 & 332,71 & $-2,36$ & $\mathbf{0 , 0 7}$ & $\mathrm{ns}$ \\
\hline & 60 & 747,09 & 264,05 & $\mathbf{8 3 5 , 3 3}$ & 175,61 & $-0,56$ & 0,60 & $\mathrm{~ns}$ \\
\hline
\end{tabular}

DP - Desvio Padrão

NS- não estatisticamente significante para $p<0,05$ 
REFERÊNCIAS BIBLIOGRÁFICAS 


\section{REFERÊNCIAS BIBLIOGRÁFICAS}

1. AHERNE, W.A. Methods of counting discrete tissue components in microscopial sections. J. Roy. Micr. Soc., v.87, p.493-508, 1967.

2. AMORIM, J.C.F. Reparação gengival após a técnica de gengivectomia e aplicação de laser em baixa intensidade. Avaliação clínica e biométrica em humanos. São Paulo, 2001. 121p. Dissertação (mestrado profissionalizante) Faculdade de Odontologia, Universidade de São Paulo.

3. ANDERS, J.J.; et al. FGF expression increases with low power laser irradiation during healing of cutaneous wounds in normal and diabetic psammomys obesus. Lasers Surg. Med., suppl. 14, p.12, abstract 41, 2002.

4. AREMBAND, D.; WADE, B. A comparative wound healing study following gingivectomy by electrosurgery and knives. J. Periodont. Res., v.8, n.1, p.42-50, 1973.

5. BASFORD, J.R. Low intensity laser therapy: Still not an established clinical tool. Lasers Surg. Med., v.16, p.331-42, 1955.

6. BRAVERMAN, B.; et al. Effect of helium-neon and infrared laser irradiation on wound healing in rabbits. Lasers Surg.Med., v.9, p.50-58, 1989.

7. CARRILlO, J.S.; et al. A randomized double blind clinical trial on the effectiveness of helium-neon laser in the prevention of pain, swelling and trismus after removal of impacted third molars. Int. dent. J., v.40, p. 31-36, 1990.

8. CHOMETTE, G. et al. Effect of the soft laser on gingival connective tissue. II Effect on wound healing. Optical microscopy, histoenzymology and electron 
microscopy studies. J. Biol. Buccale, v.15, n.1, p. 51-7, Mar.,1987. (resumo)

9. CHOMETTE, G. et al. Effect of the soft laser on gingival connective tissue. I Effect on fibroblast. Histoenzymology and electron microscopy study. J. Biol. Buccale, v.15, n.1, p. 45-9, Mar.,1987. (resumo)

10. CLOKIE, C.; BENTLEY, K.C.; HEAD, T.W.; The effects of the helium-neon laser on postsurgical discomfort: A pilot study. J. Canad. dent. Ass., v.57, n.7, p. 584-86, 1991.

11. CONLAN, M.J.; RAPLEY, J.W.; COBB, C.M. Biostimulation of wound healing by low-energy laser irradiation. A review. J. clin. Periodontol., v.23, n.5, p.492-96, 1996.

12. DONNENFELD O.W.; GLICKMAN, I. A biometric study of the effects of gingivectomy. J. Periodont., v.37, n.6, p.447-52, 1966.

13. ENGLER, W.O.; RAMFJORD, S.P.; HINIKER, J.J. Healing following simple gingivectomy. A tritiated thymidine radioautographic study. I. Epithelialization. J. Periodont., v.37, n.4, p.298-308, Jul/Aug, 1966.

14. FERNANDO, S.; HILL, C.M.; WALKER, R. A randomized double blind comparative study of low level laser therapy following surgical extraction of lower third molar teeth. Brit. J. oral Maxillofac. Surg., v.31, p. 170-172, 1993.

15. GOLDMAN, H.M. Gingivectomy. Oral Surg., v.4, p.1136-57, 1951.

16. GOLDMAN, L. Background to laser medicine - history, principles, and safety.

In Goldman: Laser on surgical medicine. Lancaster, PA. Technomic Publishing, 1991.

17. GROSSMAN, N.; 780nm low power diode laser irradiation stimulates 
proliferation of keratinocyte cultures: involvement of reactive oxygen species. Lasers Surg. Med., v. 22, p. 212-18, 1998.

18. HALL, G. et al. Effect of low-level energy laser irradiation on wound healing. An experimental study in rats. Swed. dent. J., v.18, p. 29-34, 1994.

19. HARRIS, D.M. Biomolecular Mechanisms of laser biostimulation. J. clin. laser Med. Surg., v.9, n.4, p.277-79, Aug. 1991.

20. HENNING, F.R. Epithelial mitotic activity after gingivectomy. Relationship to reattachment. J. Periodont. Res., v.4, n.4, p.319-24, 1969.

21. IN de BRAEKT, M.M.H.; et al. Effect of low level laser therapy on wound healing after palatal surgery in Beagle dogs. Lasers Surg. Med., v.11, p.46270, 1991.

22. INNES, P.B. An electron microscopic study of the regeneration of gingival epithelium following gingivecomy in the dog. J. Periodont. Res., v.5, n.3, p.196-204, 1970.

23. KANA, J.S. et al. Effect of low power density laser radiation on healing of open skin wounds in rats. Arch. Surg., v.116, p.293-296, 1981.

24. KARU, T. Photobiology of low power laser effects. Health Phys.,v. 56, p.691704, 1989. apud RIBEIRO, M.S. Curso clínico de laser em odontologia. Apostila de curso FUNDECTO - USP, São Paulo, 2001.

25. KARU, T.I. A suitable model for wound healing: how many times are we to stumble over the same block? Lasers Surg. Med., v.25, p.283, 1999.

26. KREISLER, M.; et al. Low-level 809nm diode laser induced in vitro stimulation of the proliferation of human gingival fibroblasts. Lasers Surg. Med., v.30, p.365-69, 2002. 
27. LABBE, R.F. et al. Laser Photobioactivation mechanisms: in vitro studies using ascorbic acid uptake and hydroxyproline formation as biochemical markers of irradiation response. Lasers Surg. Med., v.10, p.201-07, 1990.

28. LAGAN, K.M.; et al. Low intensity laser therapy $(830 \mathrm{~nm})$ in the management of minor postsurgical wounds: A controlled clinical study. Lasers Surg. Med., v.28, n.1, p.27-32, 2001.

29. LISTGARTEN, M. Ultrastructure of the dento-gingival junction after gingivectomy. J. Periodont. Res., v.7, n.2, p.151-60, 1972.

30. LOEVSCHALL, H.; ARENHOLT-BINDSLEV, D. Effect of low-level diode laser irradiation of human oral mucosa fibroblasts in vitro. Lasers Surg. Med., v. 14, p. 347-54, 1994.

31. LOWE, A.S.; et al. Effect of low intensity monochromatic light therapy (890nm) on a radiation impaired, wound healing model in murine skin. Lasers Surg. Med., v. 23, p. 291-98, 1998.

32. MESTER, E. Effect of laser rays on wound healing. Amer. J. Surg., v.122, n.4, p.532-5, 1971.

33. MESTER, E.; MESTER, A.; MESTER, A. The biomedical effects of laser application. Lasers Surg. Med., v. 5, n.1, p.31-9, 1985.

34. MISERENDINO, L.J.; PICK, R. Lasers in dentistry. Carol Stream, Quintessence Publishing, 1995c. 341p.

35. NEIBURGER, E.J. Rapid healing of gingival incisions by the Helium-Neon diode laser. J. Mass. dent. Soc., v.48, n.1, p.8-13, Spring, 1999.

36. NOVAES, A.B. et al. Visusalization of the microvascularization of the healing periodontal wound. III.Gingivectomy. J. Periodont., v.40, n.6, p.359-71, 
1969.

37. ORBAN, B.; ARCHER, E.A. Dynamics of wound healing following elimination of gingival pockets. Amer. J. Orthodont. oral Surg., v.31, p.40-54, 1945.

38. RAMFJORD, S.P.; COSTICH, E.R. Healing after simple gingivectomy. J. Periodont., v.34, p.5-19, 1963.

39. RAMFJORD, S.P.; ENGLER, W.O.; HINIKER, J.J. A radioautographic study of healing following simple gingivectomy. II. The connective tissue. J. Periodont., v. 37, p.5-15, 1966.

40. RIBEIRO, M.S. Curso clínico de laser em odontologia. Apostila de curso FUNDECTO - USP, São Paulo, 2001.

41. ROBICSEK, S. The $3^{\text {rd }}$ annual report of the Austrian Dental Association. J. Periodontol., v.36, p.265, 1965 apud LINDHE, J. Tratado de periodontia e implantodontia oral. Rio de Janeiro, $3^{\text {rd }}$. ed., Guanabara Koogan, 1999c, $720 \mathrm{p}$.

42. ROCHKIND, S.; et al. Systemic effects of low power laser irradiation on the peripheral and central nervous system, cutaneous wounds, and burns. Lasers Surg. Med., v.9, p.174-182, 1989.

43. RYDÉN, H.; et al. Effect of low power level energy laser irradiation on gingival inflammation. Swed. dent. J., v.18, p.35-41, 1994.

44. SABAG, N. et al. Epithelial reattachment after gingivectomy in the rat. $\mathbf{J}$. Periodont., v.55, n.3, p. 135-41, 1984.

45. SAKURAI, Y.; YAMAGUCHI, M.; ABIKO, Y. Inhibitory effect of low level laser irradiation on LPS-stimulated prostaglandin E2 production and cyclooxygenase-2 in human gingival fibroblasts. Europ. J. Oral Sci., v.108, 
n.1, p.29-34, Feb. 2000.

46. SKINNER, S.M.; et al. A preliminary study of the effects of laser radiation on collagen metabolism in cell culture. Aust. dent. J., v.41, n.3, p.188-92, 1996.

47. SMITH, K. The photobiological basis of low-level laser radiation therapy. Laser Ther., v.3, n.1, p.19-24, 1991. apud RIBEIRO, M.S. Curso clínico de laser em odontologia. Apostila de curso FUNDECTO - USP, São Paulo, 2001.

48. SOUDRY, M. et al. Effect of a helium- neon laser on cellular growth: an in vitro study of human gingival fibroblasts. J. Biol. Buccale, v.16, n.3, p.129-35, Sep. 1988. Abstract

49. STAHL, S.S. Gingival healing II. Clinical and histologic repair sequences following gingivectomy. J. Periodont., v.39, n.2, p.109-18, Mar., 1968.

50. STAHL, S.S.; TONNA, E.A. Cell proliferative activity of injured periodontal tissue. An $\mathrm{H}^{3}$ thymidine autoradiographic study of 26-week-old mice following gingivectomy. J. Periodont. Res., v.7, n.4, p.328-33, 1972.

51. STEINLECHNER, C.; DYSON, M. The effect of low-level laser therapy on the proliferation of keratinocytes. Laser Therapy, v.5, n.2, p.65, 1993. apud TUNÉR, J.; HODE, L. Laser therapy in dentistry and medicine. Edsbruk, Prima Books, 1996, 236p.

52. STRANG, R.; MOSELEY, H.; CARMICHAEL, A. Soft lasers - have they a place in dentistry? Brit. dent. J., v.165, p.221-25, 1988.

53. TUNÉR, J.; HODE, L. It's all in the parameters: A critical analysis of some wellknown negative studies on low-level laser therapy. J. clin. Laser Med. Surg., v.16, n.5, p.245-48, 1998.

54. TUNÉR, J.; HODE, L. Laser therapy in dentistry and medicine. Edsbruk, 
Prima Books, 1996, 236p.

55. WAERHAUG, J. Depth of incision in gingivectomy. Oral Surg., v.8, p.707-18, 1955.

56. WALKER, M.D.; et al. Effect of low intensity laser irradiation (660 nm) on a radiation-impaired wound-healing model in murine skin. Lasers Surg. Med., V.26, n.1, p.41-47, 2000.

57. WALSH, L.J. The current status of low-level laser therapy in dentistry. Part 1. Soft tissue applications. Aust. dent. J., v.42, n.4, p.247-54, 1997.

58. WEBB, C.; DYSON, M.; LEWIS, W.H.P. Stimulatory effect of 660nm low level laser energy on hypertrophic scar derived fibroblasts: Possible mechanisms for increase in cell counts. Lasers Surg. Med., v.22, p.294-301, 1998.

59. WEIBEL, E.R. Stereological methods. Practical methods for biological morphometry. London, Academic Press, 1979.

60. WEIBEL, E.R. Stereological principles for morphometry in electron microscopic cytology. Int. rev. Cytol., v.26, p.235-302, 1969.

61. WILDEN, L.; KERTHEIN, R. Import of radiation phenomena of electrons and therapeutic low-level laser in regard to the mitochondrial energy transfer. $\mathbf{J}$. clin. Laser Med. Surg., v.16, n.3, 1998.

62. YU, W. et al. The effects of photo-irradiation on the secretion of TGF- $\beta$ \& PDGF from fibroblasts in vitro. Lasers Surg. Med., suppl. 6, p.8, 1994, abstract 34.

63. YU, W.; NAIM, J.O.; LANZAFAME, R.J. Effects of photostimulation on wound healing in diabetic mice. Lasers Surg. Med., v.20, n.1, p.56-63, 1997.

64. ZENTLER, A. Suppurative gingivitis with alveolar involvement. A new surgical procedure. J. Amer. med. Ass., v.71, p.1530-34, 1918. apud LINDHE, J. 
Tratado de periodontia e implantodontia oral. Rio de Janeiro, 3. ed., Guababara Koogan, 1999c, 720p.

65. ZEZELL, D.M. Curso clínico de laser em odontologia. Apostila de curso FUNDECTO-USP, São Paulo, 2001. 
ABSTRACT 


\section{ABSTRACT \\ CLINICAL AND HISTOLOGICAL EVALUATION OF THE EFFECTS OF \\ LOW-LEVEL LASER (GaAIAs) ON WOUND HEALING FOLLOWING GINGIVECTOMY IN HUMANS}

The main goal of this research was to clinically and histologically evaluate the effects of Aluminum Gallium Arsenate laser - 670nm in acceleration of wound healing after gingivoplasty in 13 patients. After surgery the right side of the patient (test group), received a laser dose of $4 \mathrm{~J} / \mathrm{cm}^{2}$, in 48 -hour intervals, during one week, totalizing 4 sessions. The left side (control group) did not receive irradiation. Five blind observers evaluated the clinical aspect of wound healing through photography of the treated areas at post surgical periods of 7, 14, 21,30, 60 days. There was a tendency of choosing sometimes one side, sometimes the other as better healed until 21 days, and for the following periods both sides were considered equal. For histological analysis, incisional biopsies were performed on the mesial papilla of canines on both sides. Specimens were taken at 7, 14, 21 and 60 days post surgically. Morphometric analysis was carried out at epithelium and connective tissue and revealed normal healing parameters for both sides. For clinical evaluation the Sign and Kappa tests were used as statistical analysis. There was little agreement between examiners (mean Kappa values of 0,17 to 0,36). For the morphometric study, differences between the control group and experimental group were analyzed using the Student's paired $\mathrm{t}$-test with a confidence interval of $5 \%(\mathrm{p}<0,05)$. The results obtained did not show statistically significant differences between the groups suggesting that clinically and histologically the laser therapy did not influence the healing of oral mucosa. 